\title{
Identity Ignited: The Politicisation of Ethnicity in Fiji and New Caledonia
}

by

KJELL FOLLINGSTAD ANDERSON, B.A.

A thesis submitted to

The Faculty of Graduate Studies and Research

in partial fulfilment of

the requirements for the degree of

Master of Arts

The Norman Paterson School of International Affairs

Carleton University

Ottawa, Ontario

July 28,2004

(C)2004, Kjell Anderson 


$\begin{array}{ll}\begin{array}{l}\text { Library and } \\ \text { Archives Canada }\end{array} & \begin{array}{l}\text { Bibliothèque et } \\ \text { Archives Canada }\end{array} \\ \begin{array}{l}\text { Published Heritage } \\ \text { Branch }\end{array} & \begin{array}{l}\text { Direction du } \\ \text { Patrimoine de l'édition }\end{array} \\ \begin{array}{l}\text { 395 Wellington Street } \\ \text { Ottawa ON K1A 0N4 }\end{array} & \begin{array}{l}\text { 395, rue Wellington } \\ \text { Ottawa ON K1A ON4 } \\ \text { Canada }\end{array} \\ \end{array}$

Your file Votre référence ISBN: 0-612-98948-8

Ourfile Notre référence

ISBN: 0-612-98948-8

NOTICE:

The author has granted a nonexclusive license allowing Library and Archives Canada to reproduce, publish, archive, preserve, conserve, communicate to the public by telecommunication or on the Internet, loan, distribute and sell theses worldwide, for commercial or noncommercial purposes, in microform, paper, electronic and/or any other formats.

The author retains copyright ownership and moral rights in this thesis. Neither the thesis nor substantial extracts from it may be printed or otherwise reproduced without the author's permission.
AVIS:

L'auteur a accordé une licence non exclusive permettant à la Bibliothèque et Archives Canada de reproduire, publier, archiver, sauvegarder, conserver, transmettre au public par télécommunication ou par l'Internet, prêter, distribuer et vendre des thèses partout dans le monde, à des fins commerciales ou autres, sur support microforme, papier, électronique et/ou autres formats.

L'auteur conserve la propriété du droit d'auteur et des droits moraux qui protège cette thèse. $\mathrm{Ni}$ la thèse ni des extraits substantiels de celle-ci ne doivent être imprimés ou autrement reproduits sans son autorisation.
In compliance with the Canadian

Privacy Act some supporting forms may have been removed from this thesis.

While these forms may be included in the document page count, their removal does not represent any loss of content from the thesis.
Conformément à la loi canadienne sur la protection de la vie privée, quelques formulaires secondaires ont été enlevés de cette thèse.

Bien que ces formulaires aient inclus dans la pagination, il n'y aura aucun contenu manquant. 


\begin{abstract}
This thesis attempts to provide a conceptual framework for the analysis of the politicisation of ethnicity in Fiji and New Caledonia. Commencing with a discussion of the relevance of various theoretical approaches to ethnic identification in understanding ethnic politicisation, the author selects the instrumentalist approach of Crawford and Lipschutz as possibly the most useful. In critiquing this approach, the author contrasts assertive with defensive politicisation. Defensive politicisation may be defined as politicisation that is driven by perceived marginalisation and hardship; whereas assertive politicisation is rooted in positive entitlements. The author argues that assertive politicisation generally characterises the Fijians in Fiji, whereas defensive politicisation prevails among the Kanaks of New Caledonia; thus the case of New Caledonia seems to conform with Crawford and Lipschutz's theory while the case of Fiji does not. This central argument is presented through an examination of ethnic politicisation in historical and contemporary Fiji and New Caledonia, as well as the roles played by governing elites in both states. This thesis concludes by cautioning on the relativity of generalised theoretical constructs which may fit one particular case but not another.
\end{abstract}




\section{Dedication}

\section{Captive}

In this hectic city life

You are

Caught in the rat-race,

Come with me to the village -

Where we lay on woven mats

And dream in serenity.

Come with me to the village -

Where we greet strangers

With intimacy and humanity.

Come with me to the village -

Where I, a villager

Will carve your

Name in my heart.

- S. Ngwele (from Bamboo Leaves)

I would like to dedicate this work to all my friends in the Pacific who always did treat me with intimacy and humanity and who made my time there so special. I have carved all of your names upon my heart. 


\section{Acknowledgments}

There are many people who help you on your way through life. First and foremost I would like to thank my family for all their love and support. I would especially like to thank my father for all his encouragement at every stage of my research. My friends also have been essential to help keep me motivated (especially Reid for his computer help). Thanks, Marla, for all your support and love.

I would also like to thank: Sylvain Pabouty for his indispensable help with my work in New Caledonia; Jimmy Naunaa (formerly of the Nuclear Free and Independent Pacific) for introducing me to Sylvain; Taliai Rasolo and Col. Mua in Fiji for their help in setting up interviews; everybody who generously gave their time to be interviewed by me; Nii-K Plange for hosting me at the sociology department of the University of the South Pacific; Mahendra Chaudhry for his kind hospitality and willingness to speak to me; Stewart Firth and his Pacific Politics class for their stimulating discussions; the Centre culturel Tjibaou; Vijay Naidu for his advice; my colleagues and friends at the Norman Paterson School of International Affairs; my advisor Jared Keil for all his hard work; and my supervisor David Carment for his support and help thoughout the entire thesis process and my time at Carleton. Thank-you's must also go out to my USP professors in 1998: Robert Nicole, Elise Huffer, and Warwick Murray. The University of the South Pacific also deserves a special mention for affording me such rewarding academic and personal experiences.

I must also thank my friends and fellow USP students: Gabrielle, Sachida, Ralifo, Lance, and Reagan (not forgetting everyone else) for making 1998 a great year; Donna Hoerder for her friendship; Avisaki Ravuvu and the Ravuvu family for their generosity, friendship, and rugby tickets; Rudolph Djorahouaniahu for being a great roommate and friend; " $T$ " in Rarotonga for the art; Avelina Rokoduru, Lindsey and the rest of the group at the Centre for Development Studies; Eddie (yu no mo tha sky yet); Fraser Clark and family; and Savaira Tubou for being both my guide to Fijian culture and a friend.

There are many other people who helped me: Apisai Bola and Naisaumua village for opening his home to me; Michael (at Snack Hameau) in Nouméa for the food and political conversations; the doctors in Koné, New Caledonia for putting me back together again; Eva at USP; Jean Luc and Goosana village; and last, but not least, everybody who picked up the somewhat bedraggled graduate student at the side of the road. 


\section{Table of Contents}

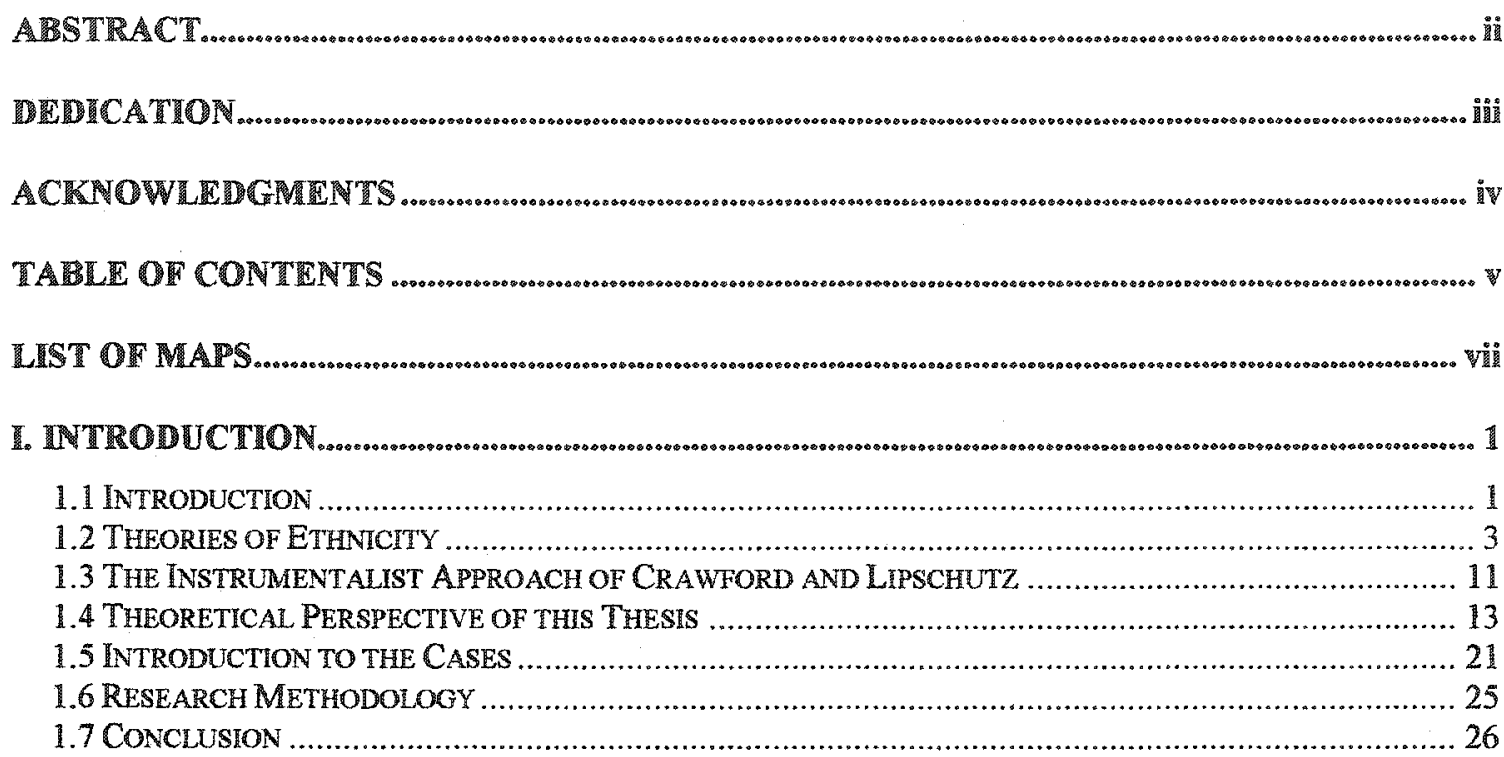

II. HISTORICAL ANALYSIS: THI POLITICUSATION OF ETHNICITY OVER TIME IN FIJI AND NEW CALEDONIA

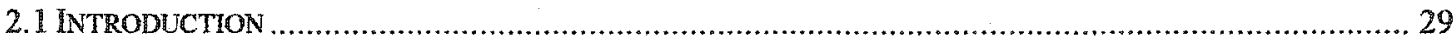

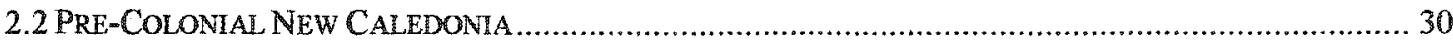

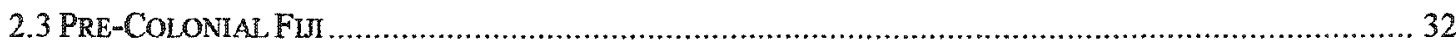

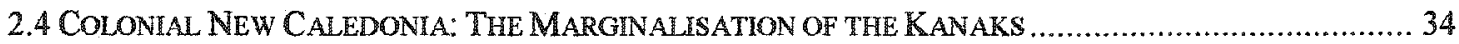

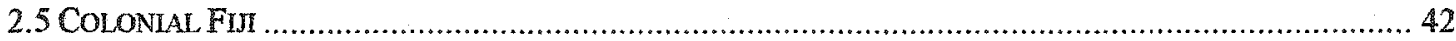

2.6 LES EVÉNEMENTS: THE KANAK CHALlENGE TO THE COLONIAL STATE IN NEW CALEDONIA ............ 48

2.7 FiJan Politicis ation and Nationalism in tHe Post-Colonial PERIOD ............................... 53

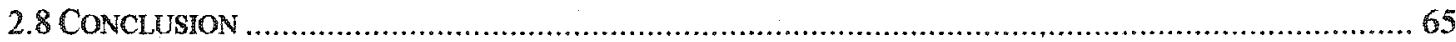

II. CONTEMPORARY ETHNIC POLITICS AND POLITICISATION IN NEW CALIDONIA .67

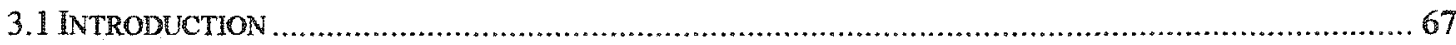

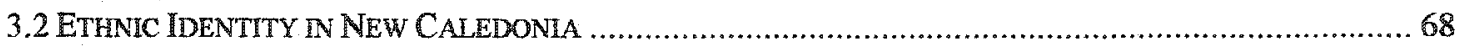

3.3 ETHNIC COMPETITION AND THE POLITICISATION OF ETHNICITY IN NEW CAE EDONIA ........................ 76

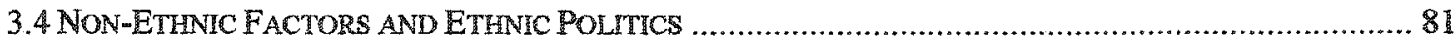

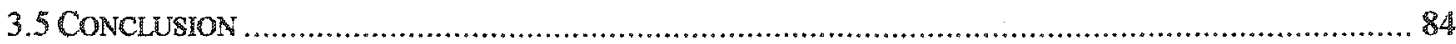

IV. CONTEMPORART

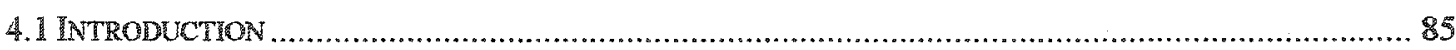

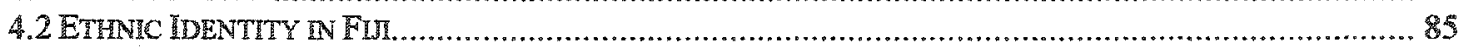

4.3 ETHNIC COMPETTION AND THE POLITICISATYON OF ETHNICTTY IN CONTEMPORARY FiJI................. 92

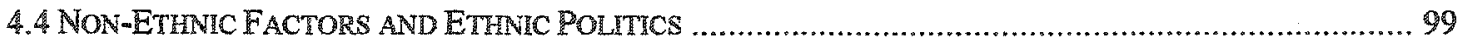

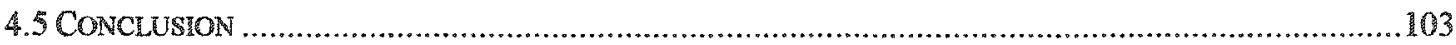

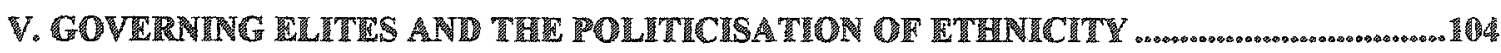

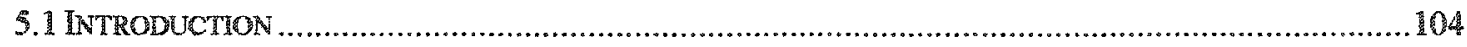

5.2 GOVERNING ELITE IN NEW CALEDONIA: THE RPCR STATE ....................................................106

5.3 GOVERNING ELITE IN FU: THE MILITARY-TRADITIONAL COMPLEX .............................................109

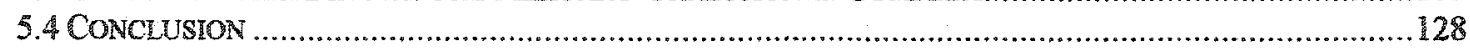

W. CONCLUSION

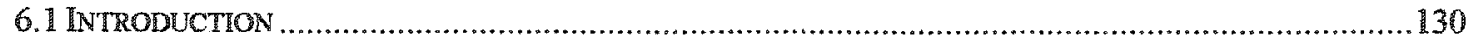


6.2 EVDENCE/SUMMARY

6.3 Prognosis: THE Future of POLTICISEd ETHNICITY IN FIJI AND NEw CALEDONIA …..................135

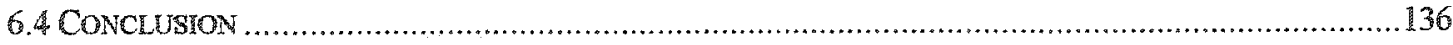

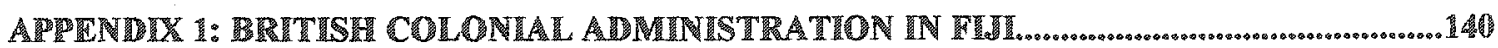

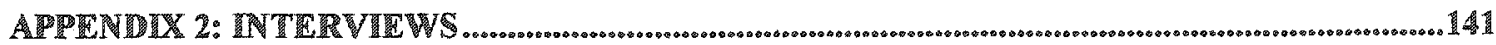

PIIILIOGRAPHW 


\section{List of Maps}

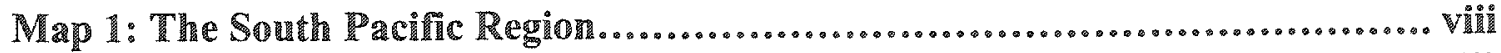

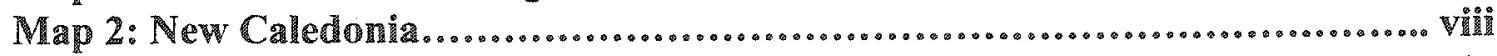

Map 3: Traditional Confederacies of Fiji.................................................

Map 4: Fiji Islands................................................................... 

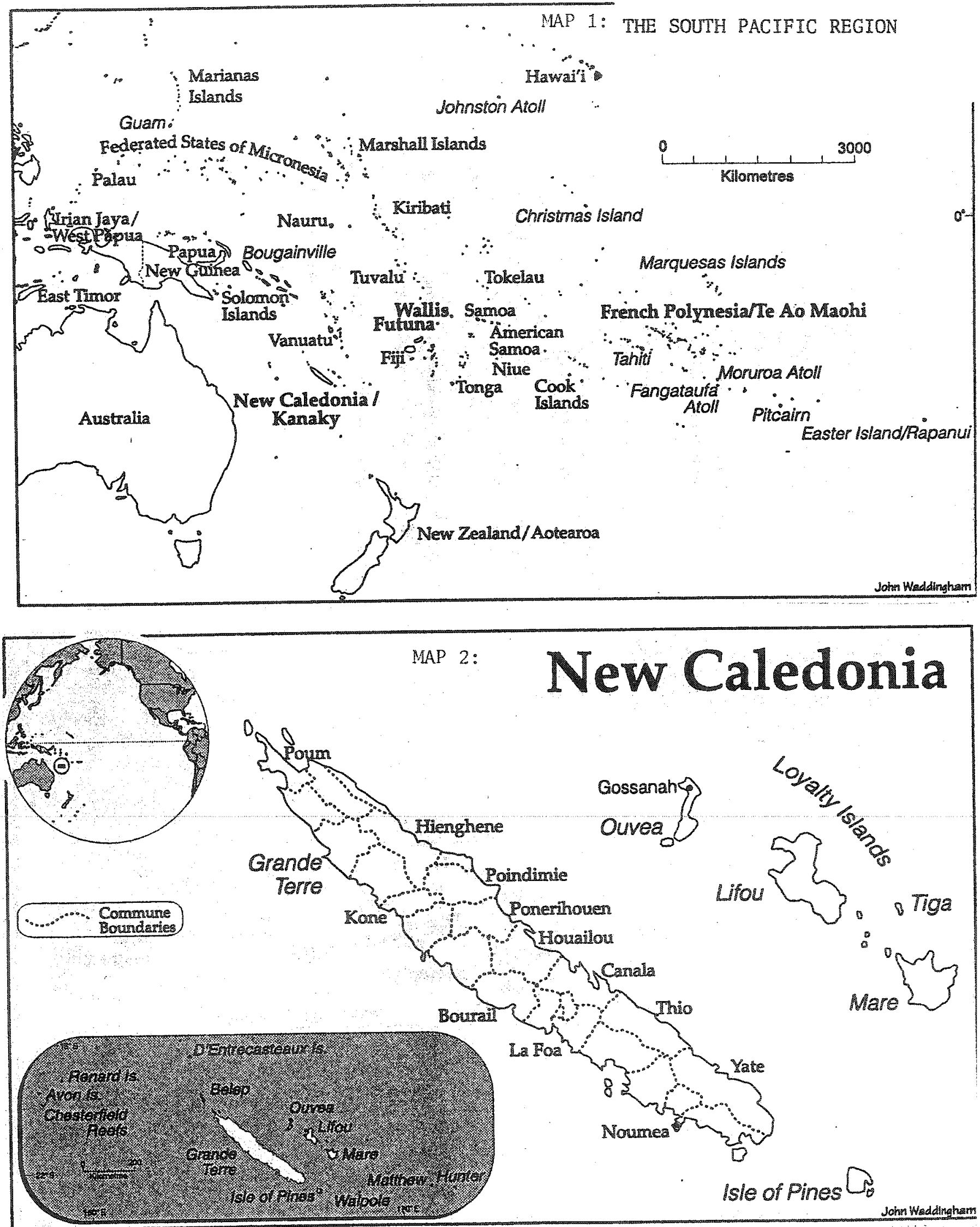

Maps from N. Maclellan and J. Chesneaux, After Moruroa: France in the South Pacific。 Melbourne: Ocean Press, 1998, pp 4 and 6. 
MAP 3: TRADITTONAL CONFEDERACIES OF FIJI

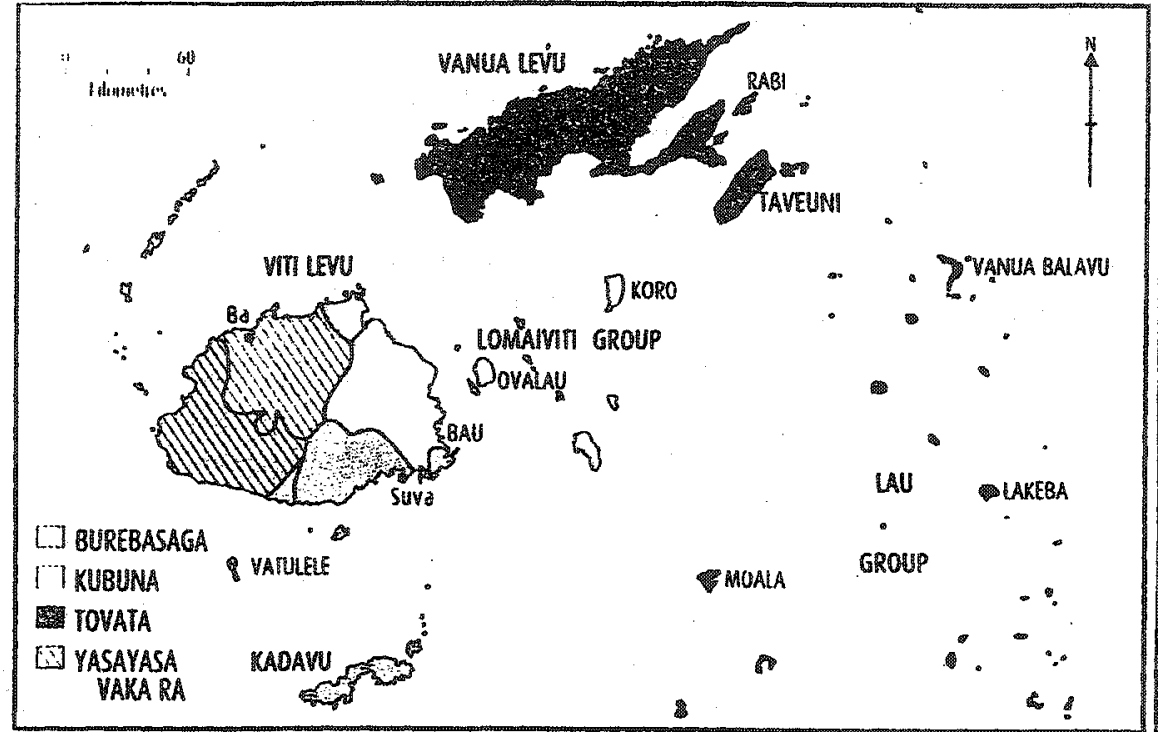

MAP 4: FIJI ISLANDS

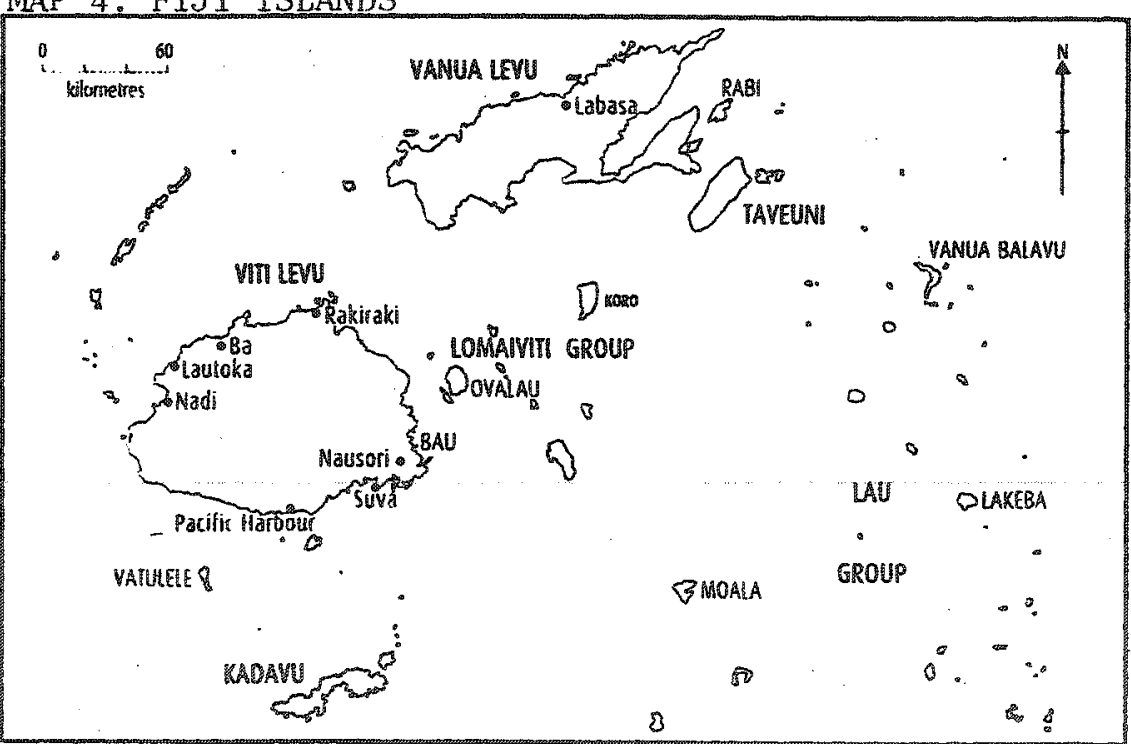

Maps from B.V.Lal and M. Pretes (eds.), Coup:

Reflections on the Political Crisis in Fiji. Canberra:

Pandanus Books, 2001, p. vi. 


\section{Identity Ignited: The Politicisation of Ethnicity in Fiji and New}

\section{Caledonia}

\section{Introduction}

\subsection{Introduction}

When ethnicity becomes a political force it is a potent thing. Most conflicts today are internal conflicts rooted in aspects of identity such as ethnicity and religion. Identitybased conflicts are often difficult to resolve and in their most extreme form they can result in gross human rights violations such as genocide and crimes against humanity. The question of how ethnicity is transformed from a social phenomenon to a political one is thus of seminal importance to an understanding of conflict.

There is a great amount of research on ethnic identification and politicisation. These theories ascribe the motives for ethnic identification to such factors as biological imperative, primordial ties, and strategic political gain. In their book The Myth of Ethnic Conflict Beverly Crawford and Ronnie D. Lipschutz attribute the politicisation of ethnicity to discrimination and disproportionate hardship (what I have labelled "defensive politicisation"). Crawford and other similar theorists fail in that they present only a partial explanation for the politicisation of ethnicity. They emphasise the role of adversity in the politicisation of ethnic identity but fail to account for cases where politicisation occurs without such factors being present. There is also an "assertive politicisation" of ethnicity 
where a group is not necessarily discriminated against but senses the cultural and political possibilities of the nation.

Both assertive and defensive politicisation are rooted in a group's perceived lack of control. This perception originates in certain conditions that make the mobilisation of ethnicity possible. These conditions include such things as the distribution of political and economic power, land rights, historical memory, and relative demographic strength. Elites also have a significant role by employing ethnic appeals both in order to acquire and maintain their power. This thesis will critique Crawford and Lipschutz, utilising the cases of the politicisation of Fijian (Fiji) and Kanak (New Caledonia) identity. ${ }^{2}$

This chapter will establish the theoretical basis for this thesis and introduce the cases. It will summarise and critique the major theoretical approaches to the study of ethnic identification. From this critique of existing theories, the theoretical basis of this thesis will be built. Chapter Two examines the politicisation of Fijian and Kanak identity over time. Chapters Three and Four focus on the conditions that drive the continuing politicisation of ethnicity and contemporary ethnic politics in Fiji and New Caledonia. Chapter Five investigates the role of governing elites in the politicisation of ethnicity. Finally, Chapter Six draws conclusions from the findings of this study. As the cases illustrate, although the politicisation of ethnicity may occur as a result of real or perceived marginalisation, it is not the only possible causation.

\footnotetext{
1 Benedict Anderson has argued that this is the primary way that ethnicity is politicised. He also argues that this process is driven by a bourgeoisie intelligentsia.

2 In this thesis the term "Fijian" is primarily used to designate the indigenous (Melanesian) people of Fiji while the term "Indian" is used for those Fiji Islanders of Indian ethnicity. These tems have been chosen because they are predominant in the academic literature both within Fiji and internationally. Moreover, the constitution and government have adopted this terminology and Fiji Indians usually self-identify as
} 


\subsection{Theories of Ethnicity}

\section{a.) Introduction}

There are myriad theories used to explain the phenomenon of ethnic identification and politicisation. This literature spans the academic disciplines of sociology, anthropology, history, and political science. These theories can be divided into a couple of very broad categories. There are those theoretical approaches that emphasise the rigidity and primordial nature of ethnic identity (such as primordialism and sociobiology), and those theories that contend that ethnicity is fluid (such as assimilationism, constructionism, instrumentalism, revisionism, and circumstantialism). This section will briefly discuss the most significant theoretical approaches to ethnic identification and assess their utility in the examination of the politicisation of ethnicity.

\section{b.) Assimilationism}

Assimilationism conceives of ethnicity as a cultural phenomenon, whereas race is biological. ${ }^{3}$ Ethnic identity is something variable and is, in fact, expected to weaken during the process of assimilation. This theory was predominant in the first half of the twentieth century and was primarily focused on the circumstances of immigrants in North America. Assimilation theory has been widely criticised in contemporary sociological literature for various reasons, including that it is too deterministic and that it does not explain why some groups may experience a faster rate or greater degree of assimilation

\footnotetext{
"Indians." The terms "Melanesian" and "indigenous Fijian" are also used interchangebly in this thesis for "Fijians" as is the term "Indo-Fijian" for "Indians."

${ }^{3}$ See Nathan Glazer and Daniel P. Moynihan (eds.), Beyond the Melting Pot, (Cambridge, USA: The MTT Press, 1963); Milton M. Gordon, Assimilation in American Life, New York: Oxford University Press, 1964); and Robert Ezra Park, Race and Culture, (Glencoe, Illinois, USA: The Free Press, 1950).
} 
than other groups. ${ }^{4}$ Moreover, assimilationism fails to account for the politicisation of minority groups that has occurred in many countries. Assimilationist assumptions would predict that such groups would simply be absorbed into stronger majority identities. If this was the case then the world would be steadily moving towards a situation where ethnic minorities simply did not exist. This is far from the truth. In fact, there are few, if any, ethnically homogenous states today. ${ }^{5}$

Furthermore, assimilationism might be more accurately labelled as being an analysis of process rather than a theory. This is where it can be useful. There are cases where cultural assimilation has occurred and the policy of assimilationism is alive and well in some states (though it generally bears a more innocuous label. ${ }^{6}$

The assimilationist theoretical approach has little to say about the politicisation of ethnicity. Assimilationist policies, which seek to absorb minorities into majority identities, can be said to be attempts to undermine ethnic politicisation. Paradoxically, such policies can actually have the effect of marginalising particular groups and therefore can contribute to their politicisation. In New Caledonia, the French colonial government has sought to assimilate Kanak identity into metropolitan French culture.

\section{c.) Revisionism}

4 Alan B. Anderson, "The Complexity of Ethnic Identities: A Postmodern Reevaluation," Identity, I (3), $2001: 210$.

5 . Even the most homogenous states are becoming increasingly diverse as the labour mobility that has accompanied globalisation extends its scope.

${ }^{6}$ One example of cultural assimilation might be the case of some early immigrants to Canada and the United States. There are many people in both countries (such as some Ukrainians, Norwegians, Germans, etc.) who have nearly completely assimilated into more predominant ethnic groups and civic nationalism. Nevertheless, there are varying degrees of assimilation. 
As A.B. Anderson points out, there are many "new" or "revisionist" theories of ethnicity that seek to challenge some of the assumptions of assimilationism. ${ }^{7}$ These revisionist theories often focus on the complexity of identity. In stark contrast with assimilationist theories, revisionism argues that not only does the saliency of minority ethnicity not necessary decrease over time, but that it may actually strengthen. The third or fourth generation of an immigrant population might seek to re-discover their identity as a means of empowerment. Sometime very old identities might even be re-invented and resurrected. In such cases of "identity resurrection" there is almost always a political element. ${ }^{8}$ Revisionism is not very relevant in Fiji and New Caledonia where more emphasis has been placed on the preservation and evolution of existing ethnic identities.

\section{d.) Primordialism and Sociobiology}

Cornell and Hartmann argue that the failure of assimilation theory to reflect ethnic reality produced two theoretical responses:

One, which came to be known as primordialism, suggested that the fundamental, intractable power of ethnicity had derailed the assimilation train. The other response, which came to be know as circumstantialism or instrumentalism, claimed the opposite: that ethnicity's malleability and flexiblity were to blame, the fact that it was so easily affected by changes in circumstances and could be used for so many purposes. ${ }^{9}$

\footnotetext{
7 A.B. Anderson, "The Complexity..." 209. See also S. Hall, "The New Ethnicities," in J. Donald and A. Rattansi (eds.), Race. Culture. and Difference, (London: Sage, 1992); M. Novak, Unmeltable Ethnics: Politics and Culture in American Life, (London: Transaction, 1996); S. Steinberg, The Ethnic Myth: Race, Ethnicity and Class in America, (Boston: Beacon, 1981); and S. Stern and J.A. Cicala (eds.), Creative Ethnicity: Symbols and Strategies of Contemporary Ethnic Life, (Logan, USA: Utah State University Press, 1991).

${ }^{8}$ Examples include the Africanisation and Zionist movements.

9 S. Comell and D. Hartmann, Ethnicity and Race: Making Identities in a Changing World (Thousand Oaks, CA: Pine Forge Press, 1998).
} 
Primordialism was first set out by Clifford Geert, who argued that there are certain "givens" of social existence such as "being born into a particular religious community, speaking a particular language...and following particular social practices."10 Moveover, these shared attributes have an "ineffable, and at times overpowering, coerciveness in and of themselves..." Primordial ties crystallize around "assumed blood ties, race, language, region, religion, and custom." Ethnic conflict is a result of long histories of antipathy between nations. Conflict is difficult to resolve, as to do so would entail a transformation of historical consciousness. ${ }^{13}$

Sociobiology is an extension of primordialism that analyses human behaviour within a biological framework. Parallels for human behaviour can be found in the animal kingdom. Sociobiology contends that ethnicity is biological and that it is natural for people to identify with each other on the basis of shared characteristics. Moreover, bonding with like individuals and rejecting the "other" is an ancient human impulse. Those who favour a sociobiological approach to ethnicity often argue that ethnic conflict is rooted in cultural dissensus and that situations of ethnic pluralism are ripe for conflict.

Like assimilationism, primordialism also has significant flaws as a theoretical approach. Labelling ethnic identity and affiliation as some kind of biological imperative

10 C. Geertz, Old Societies and New States (New York: Free Press, 1963) 109. See also H.R. Isaacs, Idols of the Tribe: Group ldentity and Political Change, (Cambridge, USA: Harvard University Press, 1975) and P.L. van der Berghe, Does Race Matter?, (New York: Elsevier, 1981).

11 Geerz 109.

12 Anderson, "The Complexity..." 211.

13 Michael E. Brown, "The Causes of Internal Conflict," in Nationalism and Ethnic Conflict, Michael E. Brown, Owen R. Coté, Sean M. Lymn Jones and Steven E. Miller (eds.), (Cambridge, Massachusetts: The MIT Press, 2001), 3. For example, American political commentator Richard Cohen once wrote that: "Bosnia is a formidable, scary place of high mountains, brutish people, and tribal grievances rooted in history and myth born of boozy nights by the fire. It's the place where World War I began and where the wars of Europe persist, an ember of hate still glowing for reasons that defy reason itself." 
is erroneous. Ethnicity and personal identity are complex and somewhat fuid. ${ }^{14}$ This is a fundamental flaw of primordialism: ethnic identity is a social phenomenon and is not primordial in character. Nevertheless, primordialism is useful in that people do coalesce into groups, and this impulse should not be underestimated. ${ }^{15}$

There is a certain normative aspect to primordial theories in that they assume that culture will always be a source of not only difference but also conflict. The increased presence and strength of multiple cultural identities within the same political space is deemed to be a destabilising force. But primordialism does not adequately account for the many cases of states that successfully manage multiple identities within the same political space. ${ }^{16}$ Moreover, primordialism does not explain why some ethnic conflicts become violent while others do not. ${ }^{17}$

Primordialism is of limited utility for the examination of the politicisation of ethnicity because it fails to make the distinction between politicised identities and nonpoliticised identities. This is crucial because, as Crawford argues, "cultural identities lead to conflict only when they have become politically charged." ${ }^{18}$ Thus, primordialist arguments about the 'danger' of ethnicity fail to actually explain how ethnicity may become politicised and act as a catalyst for conflict. From a primordialist perspective, the

${ }^{14}$ Alternative personal identifications abound. For instance, I once met a Caucasian American who had lived in Shanghai from the age of 15 until his present age of 45 . He was home visiting his American family for the first time in many years. He felt quite disoriented in the United States and spoke English with more difficulty than Chinese. He certainly considered himself to be more Chinese than American. Post modern theoretical approaches have emphasised the increasing complexity of identity in a globalised world.

${ }_{15}$ The saliency of ethnic ties has been partly illustrated by the glut of ethnic secessionist movements that have arisen in Eastern Europe since the end of the Cold War and the fall of communism. Despite decades of attempts at assimilationism and nation building (in the form of civic nationalism and federal constitutions), old nationalisms never died and with the removal of coercive pressures, they re-emerged as secessionism. Examples of this are the division of Czechoslovakia into the Czech Republic and Slovakia, the disintegration of the Soviet Union, and the disintegration of Yugoslavia.

${ }^{16}$ Countries such as Canada and Switzerland have managed to do this without the presence of violent conflict.

17 Brown 3. 
politicisation of ethnicity in Fiji and New Caledonia is somewhat inevitable as there are significant cultural and historical differences present between the ethnic groups in each case. Moreover, such differences are, more likely than not, to lead to conflict of some type.

\section{c.) Constructionism}

Constructionism focuses on the "construction" of ethnic identity. ${ }^{19}$

Constructionism, like circumstantialism, makes the assumption that ethnicity is a variable, social phenomenon. Where the two approaches differ somewhat however is that constructionism not only labels ethnic identity as being fluid but seeks the sources of identity mutation. Ethnic entrepreneurs and other insiders are often viewed as being agents for change. According to Cornell and Hartmann, "ethnic groups are actively involved in the construction and reconstruction of identities, negotiating boundaries, asserting meanings, interpreting their own pasts, resisting the impositions of the present, and claiming the future." 20 Another important characteristic of constructionism is a focus on the degree and scope of ethnic identity. ${ }^{21}$

One of the most influential constructionist theories is Benedict Anderson's "imagined community." The imagined community asserts that ethnicity is primarily driven by a bourgeois intelligentsia which is aware of the cultural and political

18 Crawtord 11.

19 See Comell and Hartmann.

20 Comell and Hartmann 101.

21 Cornell and Hartmann have sought to distinguish between "thick" and "thin" ethnicities. In thick ethnicities, much of social life, and individual and collective action are based on ethnic identity. In contrast, thin ethnicities exhibit a much reduced level of ethnic activity and affiliation. 
possibilities of the community. ${ }^{22}$ Ethnic identity construction and mobilisation is an elite-driven process.

Constructionism fails in that, like circumstantialism, it does not account for the ancestral basis of ethnic identity. Moreover, constructionism generally does not address the political and economic motivations that drive identity construction in certain cases. ${ }^{23}$ Therefore, constructionism does not adequately explain the politicisation of ethnicity.

This school is very prevalent in the literature on Fiji and the South Pacific.

Writers such as Stephanie Lawson have argued that "tradition" in the South Pacific is not really tradition at all, but is a relatively recent colonial construct that is now being used by ethnic entrepreneurs to mobilise power. ${ }^{24}$ Kaplan and Kelly have also written extensively about the construction of ethnic identities in Fiji. ${ }^{25}$

\section{f.) Circumstantialism and Instrumentalism}

Circumstantialism disputes the claims of the primordial approach that ethnicity is biological in its foundation and instead argues that ethnicity is socially constructed, ambiguous, and dynamic. ${ }^{26}$ People have multiple allegiances at the same time and emphasise different identities in relation to different contexts.

22 Benedict Anderson coined the phrase "imagined community."

23 Philip Q. Yang, Ethnic Studies: Issues and Approaches, (Albany: State University of New York, 2000) 46.

24 Stephanie Lawson, Tradition Versus Democracy in the South Pacific: Fij, Tonga, and Samoa, (Cambridge, United Kingdom: Cambridge University Press, 1996).

$\frac{5}{25}$ John D. Kelly and Martha Kaplan, Represented Communities: Fiji and World Decolonization, (Chicago: University of Chicago Press, 2001).

${ }_{26}$ See Abner Cohen, Customs and Politics in Urban Africa, (Berkeley: University of California Press, 1969); Stephen Steinberg, The Ethnic Myth: Race, Ethnicity, and Class in America, (Boston: Beacon, 1981); Engeen E. Roosens, Creating Ethnicity: The Process of Ethnogenesis, (Newbury Park, USA: Sage, 1989); and Orlando Patterson, "Context and Choice in Ethnic Allegiance: A Theoretical Framework and Caribbean Case Study," in Nathan Glazer and Daniel P. Moynihan (eds.), Ethnicity: Theory and Experience, (Cambridge, USA: Harvard University Press, 1975). 
Instrumentalism is similar to circumstantialism but differs in that it argues that the emphasising or choosing of a particular identity is driven by strategic political and economic considerations. Bell set out the primary arguments of instrumentalism in a 1975 article:

What I think is clear is that ethnicity, in this context, is best understood not as a primordial phenomenon in which deeply held identities have to reemerge, but as a strategic choice by individuals who, in other circumstances, would choose other group memberships as a means of gaining some power and privilege. ${ }^{27}$

Circumstantialism and instrumentalism are somewhat faulty in that they have the tendency to over-emphasise the fluidity of ethnicity. This takes ethnic identity out of the social realm and turns it into a calculated political phenomenon. Ethnicity may be used as a tool of political mobilisation, as is exhibited by ethnic entrepreneurs, but primordial ties can still be a basis for self-identification and group affiliation.

Instrumentalism focuses on the politicisation of ethnicity and the emergence of "ethnic entrepreneurs" who seek to use ethnicity to increase their power and influence. In contrast with primordialism, ethnicity is viewed as a means rather than an end. Thus, an ethnic group can be viewed as a sort of interest group, which exists to influence politics and seek power. Instrumentalism's focus on the relationship between ethnicity and politics makes it the most useful theory for the analysis of the politicisation of ethnicity. In both Fiji and New Caledonia political interests and ethnic mobilisation are closely intertwined. Moreover, ethnic entrepreneurs have been at the forefront of the politicisation of ethnicity in both cases. 


\subsection{The Instrumentaist Apuroach of Craw ford and Lipschutz}

\section{a.) Introdiduction}

This thesis will build on the instrumentalist approach of Beverly Crawford and Ronnie D. Lipschutz in the examination of its central question: how ethnicity becomes politicised. Their central argument is that the politicisation of ethnicity occurs as a result of hardship and/or discrimination. This proposition will be examined and critiqued.

\section{b.) The Myth of Ethnic Conflict}

The theoretical approach of Crawford and Lipschutz is fundamentally instrumentalist because it envisions the politicisation of identity as being a strategic response to economic adversity. According to Crawford:

Cultural identity is politicized only when it becomes a criterion for discrimination and privilege in struggles over the distribution of political and economic resources, rights, and protection. ${ }^{28}$

Therefore, the politicisation of ethnicity is largely a group's defensive reaction to external pressures.

Moreover, ethnic identity becomes politically relevant when it becomes a criterion for the distribution of resources. The state plays a central role in the distribution of resources, therefore it has the potential to increase or decrease the "political relevance of cultural identity." ${ }^{32}$ Craw ford makes the following propositions:

i. The political relevance of cultural cleavages will be sustained and in some cases even created if they are legitimized by the dominant institutions of state and economy.

27 D. Bell, "Ethnicity and Social Change," in N. Glazer and D.P. Mognihan (eds.), Ethnicity: Theory and Experience (Cambridge, MA: Harvard University Press, 1975) 17.

${ }^{28}$ Crawford 12 .

${ }^{29}$ Crawford 12. 
ii. Conversely, the political relevance of cultural identity can be weakened if it is not legitimated by those institutions.

iii. To the extent that those institutions are strong and legitimate, they can attenuate that political relevance or channel it in the direction of non-violent political competition.

iv. To the extent that the institutions are strong enough to coerce but illegitimate in the eyes of the groups excluded from preferential access to resources, resentments build but will be repressed and violence will be attenuated.

v. To the extent that institutions charged with maintaining order are weak, and to the extent that previous institutions encouraged identity politics and separatist solutions to redress grievances of particular cultural groups, the odds of violence increase. ${ }^{30}$

As Crawford argues in propositions one and two, if the state institutionalises identity cleavages, then the politicisation of identity is inevitable. ${ }^{31}$

Crawford also submits that in certain societies identity is managed through social contracts that determine the allocation of rights and resources. ${ }^{32}$ Sometimes these social contracts can only be maintained through coercive force. These social contracts are institutionalised and "cultural conflict escalates into violence when these institutions are weakened, disrupted, or transformed in ways that undermine the commitment to uphold these contracts or repress dissent. ${ }^{133}$ Crawford also argues that contrary to democratic theory, the very process of liberalisation and globalisation may help to undermine these contracts and foment conflict. ${ }^{34}$ This thesis will focus on examining Crawford and Lipschutz's basic arguments relating to the politicisation of cultural identity (identity is

${ }^{30}$ Crawford 24.

31 For example, the colonial state often undertook divide and rule policies that favoured particular identity groups over others and often constructed identity in such a way as to emphasise differences over similarities and foment ethnic consciousness and fears. The colonial state also frequently fostered elites through its indirect rule governance strategy.

32 Beverly Crawford, "The Causes of Cuitural Conflict: An Institutional Approach," in The Myth of Ethnic Conflict: Politics, Economics, and "Cultural" Violence, Beverly Crawford and Ronnie D. Lipschutz (eds.), (Berkeley, California: University of California, 1998) 5.

33 Crawford 6.

34 This is similar to the theoretical approach of Olzak and Nagel who argue that the politicisation of identity occurs when the ethnic division of labour is broken down. See Susan Olzak and Joane Nagel, "Introduction, Competitive Ethnic Relations: An Overview," in Competitive Ethnic Relations, (London: Academic Press, 1986) 4. 
politicised through adversity) rather than their broader argument about the role of global economic and political forces in fomenting this adversity.

\subsection{Theoretical Perspective of this Thesis}

\section{a.) The Nature of Identity}

Before proceeding to a discussion of the politicisation of ethnic identity, it is useful to discuss the nature of identity itself. This thesis adopts an instrumentalist view of identity as something that is socially constructed, ambiguous, contextual, and dynamic. Every individual has multiple facets to their identity and will emphasise different aspects in different contexts. ${ }^{35}$ Any of these group memberships can become politicised and a source of political mobilisation. Groups within the same identity field (category) are always relativistic. For example, there could be no notion of being "Croatian" without the relational knowledge of other ethnic groups. Therefore, by its very nature, identity can be somewhat exclusionary and the assertion of identity by one group can spur the politicisation of other groups within the same identity field.

\section{b.) Conditions that Encourage the Politicisation of Identity}

Crawford and Lipschutz's thesis is that discrimination and hardship, as well as the institutionalisation of difference, drive the politicisation of identity. ${ }^{36}$ This is only a partial explanation. ${ }^{37}$ The underlying condition that facilitates the politicisation of

\footnotetext{
${ }^{35}$ As instrumentalists such as Crawford argue, this may take a more strategic form at times.

${ }^{36}$ Similarly the historian Jonathan Sarna argues that ethnicity becomes politicised through "ascription" and "adversity."

37 In some cases the emergence of a particular identity itself represents the politicisation of that identity. Some identities do not exist until they become politically relevant. For example, in Bougainville (Papua New Guinea) there was no real sense of a "Bougainvillean" ethnicity until opposition coalesced around the construction of a mine at Panguna.
} 
identity is a group's perceived lack of control. In my view, this perceived lack of control could be manifested in two ways:

Defensive (negative entitlement): Survival and security are fundamental interests for every group and when the physical, economic, or cultural security of the group is threatened (through either discrimination or circumstance) this is a powerful force for politicisation. ${ }^{38}$ Similarly, Lake and Rothchild argue that ethnic conflict is rooted in a group's "fear of the future." This defensive politicisation is impelled by such perceptions of insecurity and hardship.

Assertive (positive entitlement): In contrast, assertive politicisation is grounded in the national imagining of a particular group. This differs from the defensive politicisation of ethnicity in that it can occur without any sense of hardship or discrimination. Moreover, groups may be indoctrinated by leaders with a sense of manifest destiny. They are given the message that there is something unique about their group and that they have certain entitlements. Mythohistories may be constructed which support this ideology. ${ }^{40}$ Indigenous nationalist movements (such as the Fijians and Kanaks) are a least partially rooted in notions of positive entitlement based on the idea of being the original inhabitants in their area.

It is important to note that defensive and assertive politicisation may both be present in any particular case. For example, the politicisation of the Kanaks in New Caledonia is defensive in that it is a response to marginalisation but also assertive because it is

\footnotetext{
38 Rothchild 127.

39 David A. Lake and Donald Rothchild, "Containing Fear: The Origins and Management of Ethnic Conflice," in Michael E. Brown, Owen R. Coté, Sean M. Lym Jones and Steven E. Miller (eds.), Nationalism and Ethic Conflict, (Cambridge, Massachusetts: The MIT Press, 2001) 126.

40 A good example of this is Sri Lanka where Sinhalese Buddhists have developed mythical accounts that support their claims to Sri Lanka.
} 
grounded in notions of indigenous positive entitlement. Moreover, the use of these two terms is intended to be a conceptual framework for the analysis of Crawford and Lipschutz rather than definitive. The utility of this framework will be discussed in the final concluding chapter. Crawford and Lipschutz's theory refers primarily to the defensive impulses at play in the politicisation of identity.

This perception of a group's lack of control (that is the fundamental cause of both assertive and defensive politicisation) may arise from one or more of the following factors: ${ }^{41}$

1. Politics and Political Institutions: this includes both the institutions of political power as well as, the competition between various actors and groups for control over these institutions. Politicised ethnicity may be institutionalised in the very structure, institutions, and character of the state. Nagel argues that the institutionalisation of ethnicity by the state will contribute to its politicisation:

Whether explicit or de facto, recognition of religious, cultural, or linguistic affiliations as bases of political participation tends to promote ethnic group organization and to transform ethnic groups into political interest groups and thus tends to increase interethnic competition. ${ }^{42}$

Furthermore according to Crawford, the stratification of identity through the institutions of the state greatly increases the likelihood of conflict. ${ }^{43}$ The state may also seek to construct a new homogenous national identity over time through exercises in identity consolidation. The more that notions of national identity seek to exclude or discriminate against groups the more likely that these groups will become

\footnotetext{
${ }^{41}$ This list is not intended to be exhaustive but rather represents some of the most important factors that drive the politicisation of identity. Land ownership is of special importance for the cases (Fiji and New Caledonia) examined in this thesis.

42 Nagel, "The political..." 101 .
} 
politicised. As Crawford and Lipschutz argue, in asymmetrical states where one group is particularly dominant over other groups, the state will construct repressive and coercive mechanisms in order to maintain its monopoly on state power.

Moreover, the relations between groups within the same identity field can drive politicisation. Ethnic security dilemmas may occur whereby groups continually seek to improve their own position in order to ensure their security vis à vis other groups. ${ }^{44}$ A cycle of escalating demands and competition between groups can develop in this way. A survival discourse may also develop whereby the fundamental survival of one group is deemed to be threatened by another. In violent conflicts these escalating demands can be transformed into a cycle of escalating fears and violence that recognises no line between past and present transgressions. It is in this way that political competition can contribute to the continuing politicisation of identity.

2. Economic Inequality and Poverty: how the government distributes economic resources and other forms of inequality and poverty in the economy that disadvantage a particular group. Crawford argues that sudden shifts in the economic status of a group may put pressure on social contracts and contribute to conflict. Moreover, in states where a particular group is dominant in the economy, other groups may feel disenfranchised and this can drive the defensive politicisation of identity. Economic hardship is the focus of Crawford and Lipschutz's argument.

3. Demographics - in certain conditions a group's demographic strength or stability might increase or decrease their perception of security. Demographic shifts can, in

${ }^{43}$ Crawford 12.

${ }^{44}$ For example, Serbian political aspirations for a Greater Serbia constituted an inherent threat to other ethnic groups within the same geographical area. See Barry Posen, "The Security Dilemma and Ethnic Conflict, Survival, 35 (1). 
particular, contribute to a group feeling as though they are becoming marginalised within a state. In cases where there are two ethnic groups that are roughly equal in size and that make up a high proportion of the general population, bipolarisation may occur. In bipolarisation political and economic life becomes increasingly ethnicised and centred on competition between two groups. In such states political competition is often an intense zero-sum game where gains by the opposing group are viewed as a loss for your group. Furthermore, minority groups are more likely to manifest the defensive politicisation of identity as they may feel that their political and economic aspirations are subsumed under those of the majority group.

4. Land Ownership - related to economic factors, land is often perceived not only as an economic resource, but also as a physical anchor for group identity and security.

5. Historical Memory - A group may have a distinctive history as an autonomous political entity that contributes to its sense that it should control its destiny. History can be a powerful factor in assertive politicisation, where a group feels that its national aspirations are unfulfilled. A history of violence and/or marginalisation targeting a particular group can also help create the conditions for defensive politicisation.

\section{c.) The Role of Governing Elites}

The exercise of state power by elites can also play a decisive role in the politicisation of ethnicity. Leaders use ethnicity as a means to gain a constituency and achieve control over the state. Once in control, these governing elites seek to perpetuate, and even reinforce, the politicisation of ethnicity in order to defend their power. 
Figure 1.1 The Politicisation of Entricity

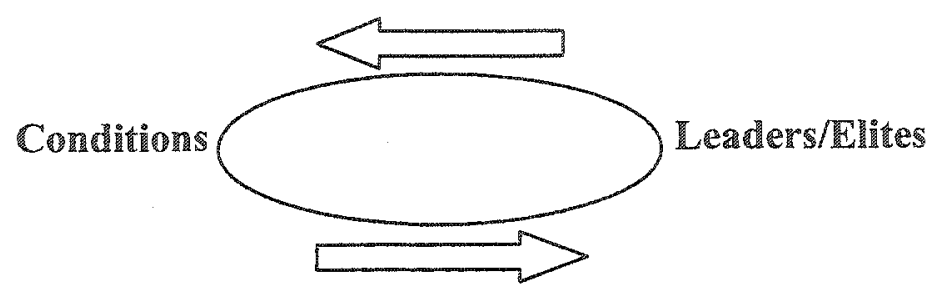

These elites can have ideological or entrepreneurial characteristics. ${ }^{45}$ Ideological elites are driven by ideology. In contrast, entrepreneurs are maximisers who use ethnicity as a means to gain a political constituency. They do this through presenting themselves as the best defenders of the security and interests of the group. In order to earn the support of their desired constituency, leaders may engage in outbidding where they attempt to show their dedication to the group through adopting a more extreme position. ${ }^{46}$ Sometimes they must also gain the support of individuals from outside of their group so they tailor their message for their audience. Ethnic entrepreneurs may establish clientelist networks to facilitate their political activities and distribute benefits to their supporters. Instrumentalist theories such as Crawford and Lipschutz recognise the importance of ethnic entrepreneurs (who serve as focal points for political activity) in the politicisation of ethnicity. Ethnic leaders may also play a role in the construction of identity and the reinterpretation of group boundaries. ${ }^{47}$

\footnotetext{
${ }_{45}$ Once again these categories are intended as a conceptual framework and are not mutually exclusive.

${ }^{46}$ Rothchild 139. See also Joseph Rothschild, Ethnopolitics: A Conceptual Framework, (New York: Colombia University Press, 1981) and Donald L. Horowitz, Ethnic Groups in Conflict, (Berkeley: University of California Press, 1985).

${ }^{47}$ The individuals that represent the constituencies for ideologues and entrepreneurs may also either act as ideologues that are driven by ideology in their political choices or they may support leaders for purely strategic reasons. Identity entrepreneurs will be appealing only to a specific aspect of an individual's identity matrix so the individual must prioritise their membership in various identity groups. Individual political choice is often a matter of such ranking.
} 


\section{d.) The Politicisation of Ethmicity and Nationalism}

Nationalist movements and nation-building are closely related to the politicisation of ethnicity. R.D. Grillo posits that nationalisms emerge in two possible ways: either through "ethnicization of the polity," where the state seeks to construct a new political community from numerous ethnic groups, or through the "politicization of ethnicity," where an emergent ethnic groups achieves statehood. ${ }^{48}$ Put another way, the ethnicisation of the polity could be thought of as attempts to construct a civic nationalism whereas the politicisation of ethnicity is ethnic nationalism. In civic nationalism "individuals give themselves a state, and the state is what binds together the nation." "In contrast, ethnic nationalism is rooted in such things as tradition, ancestry, language, and culture. ${ }^{50}$ Building a state around a particular ethnic group is often appealing not only because it offers a clear identity for the state but also because it may be the culmination of the ethno-national aspirations of your group.

Nevertheless, there are dangerous elements to ethnic nationalism. Given that the vast majority of states are heterogeneous (fewer than twenty states are ethnically homogenous in the sense that ethnic minorities account for less than five percent of the population), constructing national identity around a single ethnic group has the potential

\footnotetext{
48 Lipschutz 58. The differing ethnic configuration of post-colonial states has also helped to determine which strategy they pursue to manage identity. States where one group is very predominate are more likely to pursue an identity-based nationalism.

49 Jocelyne Couture, Kai Nielson, and Michel Seymour, Rethinking Nationalism, (Calgary: University of Calgary Press, 1998) 3 .

${ }^{50}$ Couture, Nielson, and Seymour 3 and 7 . There is some question as to whether such a thing as a true civic nationalism exists anywhere. Almost every state has a majority group that plays a large role in shaping the identity of the state. Moreover, the sort of impartial distribution of resources that is inherent in the concept of civic nationalism probably does not exist. Some commentators have argued that civic nationalism is merely ethnonationalism wearing the friendlier mask of civic nationalism. Despite these criticisms, this thesis will argue that there are different ideologies incorporated into nation-building and these ideologies produce different results.
} 
to isolate other groups. ${ }^{51}$ In the process of nation-building the state constructs a shared identity within a shared political space. In essence, the state seeks to construct a new nation and a new nationalism. ${ }^{52}$ This failure to acknowledge diversity in the nationbuilding process is what I have labelled the "nation-building trap," and can contribute to the defensive politicisation of ethnicity.

\section{e.) Ethnicity and Conflict}

There is also a strong relationship between the politicisation of ethnicity and violent conflict. Conflict is more likely in identity-based disputes than in interest-based disputes, because "while interests are malleable and multiple, making compromises and log-rolling possible, cultural identity is fixed and non-negotiable. Disputes over resources among 'identity groups' will thus prove to be particularly difficult to negotiate, raising the odds of violence." 53 As ethnic identity becomes an increasingly strong source of political affiliation and mobilisation, divisions within a state become more polarised. The stronger these divisions are, the more likely it is to lead to violent conflict. Factors that may mitigate the likelihood of violent conflicts include such things as the overarching political culture, civic norms, and the strength and representative nature of

${ }^{51}$ Brown 7. See also Dan Smith, The Penguin Atlas of War and Peace, (Hong Kong: Penguin, 2003) 17. It is also important to remember that even in states with a small percentage of minorities there are still significant minorities in many of these states. Moreover, within many of these states there are very significant regional variations and minorities may constitute the majority in some of these regions. For example, China is one state with a less than $10 \%$ minority population but Tibet Autonomous Region remains majority Tibetan.

52 According to Crawford, citizenship rights provide an example of how membership rules can increase or decrease the politicisation of identity. Citizenship can be either inclusive or exclusive. Inclusive citizenship is based on civic membership in a shared political community while exclusive citizenship restricts membership to those with specific shared attributes (i.e. an identity group). Canada is an example of a country with inclusive citizenship rules while Israel is a country with exclusive citizenship. Citizenship in the political community along with universal suffrage can weaken the political relevance of specific identity groups. Perhaps one could argue that in order to decrease the political relevance of identity the state must emphasise individual rights over communal rights. 
governance institutions. These mitigating factors may help to channel ethric conflicts away from violence and into the political realm. If there is an overarching sense of universal membership in the political community, this may also help to prevent violence. $^{54}$ Violent conflict occurs where politics end.

Both Rothchild and Crawford argue that state weakness may also be a factor that will increase the likelihood that a conflict will become violent. ${ }^{55}$ Failed states, where there is a lack of a legitimate central authority that can deliver basic needs and security, are becoming an increasing phenomenon. In such states there is no government that can effectively manage conflict and distribute resources equitably. Ethnic fears may become paramount. ${ }^{56}$ Moreover, in the absence of central authority the benefits of ethno-political alignment may increase. Violent conflict is most likely to result in those states with highly politicised ethnic identity and a lack of institutional constraints.

\subsection{Introduction to the Cases}

\section{g.) Case Selection Methodology}

This thesis will utilise the politicisation of Fijians and Kanaks as case studies to test the propositions of Crawford and Lipschutz. The central question that this thesis sets out to answer is: how does the politicisation of ethnicity occur? Crawford and Lipschutz's argument that discrimination and adversity drive the politicisation of identity is used as a basis for discussion. In order to test this proposition this thesis undertakes a structured,

${ }^{53}$ Crawford 5.

${ }^{54}$ Crawford 12.

${ }^{55}$ Rothchild 128 and Crawford 24.

${ }^{56}$ Rothchild 128. 
focussed, comparison between the politicisation of Kanaks in New Caledonia and the politicisation of Fijians in Fiji.

Both Fijians and Kanaks are politicised ethnic groups yet there are some major differences in the way that politicisation has occurred in the two cases. Foremost among these differences is the fact that although Kanak nationalism has largely been a response to marginalisation and hardship, Fijian nationalism has, for the most part, emerged not as a response to such conditions. This is largely a result of their differing colonial experiences. This is not to say that Fijians did not face any kind of disenfranchisement or adversity under British colonial rule. However, British colonial rule did not threaten the survival of the Fijians as a people, and it actually stratified ethnicity in favour of Fijians (see $1.5 \mathrm{c}$ for a further discussion of this). In contrast to the Kanaks, Fijians have also maintained their political control in the post-colonial period. Thus, the politicisation of Fijian identity was not a direct result of marginalisation either in the colonial or postcolonial periods. That Fijian nationalism could emerge without such marginalisation clearly challenges the assumptions of Crawford and Lipschutz and shows that the cultural conflict argument provides only a partial explanation for the politicisation of ethnicity.

\section{b.) Overview of the Cases}

\section{THISTORY}

Both Fiji and New Caledonia contained many small indigenous (Melanesian) nations before colonialism. Fiji became a British colony in 1874 while the French annexed New Caledonia in 1853. In New Caledonia the indigenous Kanaks faced institutional discrimination and the loss of their land. The Kanaks resisted French rule with armed 
uprisings in 1878 and 1917 and sporadic violence during Les Evénements in the 1980s. In Fiji the British colonial policy isolated and protected the indigenous Fijians. In both states indigenous identity and tradition were re-shaped by colonial rule.

Both territories also faced a massive influx of immigrants who reduced the indigenous population to a minority. In the latter decades of the twentieth century, politics in both states have revolved around bipolar competition between the indigenous people and the immigrant-origin population. Fiji achieved independence in 1970 while New Caledonia remains a French possession. ${ }^{57}$ In New Caledonia the economy is dominated by the mining and processing of nickel while in Fiji sugarcane and tourism are the foundations of the economy.

\section{- Demography}

Fiji and New Caledonia are both ethnically bipolar states in which two ethnic groups are demographically and politically dominant. The ethnic breakdown in Fiji is $52 \%$ Fijian, 43\% Indian, 2\% European and part-European, 1\% Rotuman, 1\% other Pacific Islander, and $1 \%$ Chinese and part-Chinese. ${ }^{58}$ For much of the latter half of the twentieth century Indians were actually in the majority but substantial Indian emigration (especially following the 1987 coup) has significantly reduced their population. In New Caledonia the population breakdown is $44 \%$ Kanak, 34\% European, $12 \%$ Polynesian (Wallisian, and Tahitian), 3\% Indonesian (mostly Javanese), 1\% Ni-Vanuatu, $1 \%$ Victnamese, and $5 \%$ other. ${ }^{59}$ In Fiji the indigenous people are now in the majority while in New Caledonia they remain a plurality.

\footnotetext{
57 Under the Noumea Accord New Caledonia is being granted increasing autonomy in advance of a referendum on independence in fifteen to twenty years.

58 Ron Crocrombe, The South Pacific, (Suva, Fij: Institute of Pacific Studies, 2001 ) 691.

${ }^{59}$ Crocombe 696. Wallisians hail from the French colony of Wallis and Futuna.
} 


\section{c.) Points of Comparison}

As argued previously, there are several factors (such as economic inequality and historical memory) that can contribute to a group's perceived lack of control and the politicisation of ethnicity. Some of these factors may be common to many cases while others are unique.

There are a couple of major similarities between the two cases:

- Indigenous/Non-Indigemous Conflict: In both countries ethnic conflict is occurring between an indigenous and an immigrant-origin population. ${ }^{60}$ This has profound effects on political discourse as indigenous rights and paramountcy compete with multiculturalism as national ideologies. Moreover, the importance of land in the indigenous cultures of both the Fijians and the Kanaks ensures that land rights are a contentious political issue.

- Demographics and Political Competition: In both states intense bipolarisation has ensured that political demands have evolved with demographic strength. Both states have a long history of immigration which has transformed the political landscape and reduced indigenous peoples to minorities (although Fijians are no longer in the minority).

There are also some major differences between Fiji and New Caledonia:

- The Colonim Expenience: While it is true that there is a kind of disenfranchisement inherent in all forms of colonialism, the colonial experiences of the Fijians and Kanaks did differ greatly. From the start of colonialism the Kanaks have faced great

\footnotetext{
${ }^{60}$ Both Kanak nationalism and Fijian nationalism also have strong connections with other indigenous nationalist movements elsewhere in the world.
} 
discrimination at the hands of the French. The French stole Kanak lands, attempted to destroy Kanak culture, and made the Kanaks entirely marginal in economic and political institutions. Kanak politicisation was largely born from this marginalisation. In contrast, in Fiji the British pursued a policy of indirect rule (as they did in other parts of the British Empire). This policy, while still ensuring ultimate British control, incorporated Fijian governance structures into the colonial state. Moreover, the British enshrined Fijian land rights and paternalistically protected Fijian culture. The British also favoured the Fijians over the Indians (a population that they imported) and defended Fijian rights to political paramountcy after the transition to independence.

- The Role of Political Institutions in Conflict Management: The two cases also show the role of political institutions in attenuating violence. In contrast to the Fijians in Fiji, the Kanaks in New Caledonia lacked a political channel to express their grievances, therefore they pursued extra-political means to assert their demands. ${ }^{61}$ An escalating cycle of violence developed in New Caledonia in the 1980 s that came close to full-blown civil war.

\subsection{Research Methodology}

As noted above, this thesis undertook a structured, focussed, comparison between the politicisation of Fijian and Kanak ethnicity as a means of examining the arguments of Crawford and Lipschutz. In order to gather evidence for this study field research was conducted in both Fiji and New Caledonia. This field research included time as a visiting

\footnotetext{
${ }^{61}$ The only significant insurrection against British colonial rule in Fiji was the Colo Uprising (1876), but it was more regionally-based than pan-ethnic.
} 
graduate researcher based at the Department of Sociology within the School of Social and Economic Development at the University of the South Pacific (Suva, Fiji campus) from May to December 2002. Moreover, during this period several weeks were also spent in New Caledonia conducting research.

The primary research method for this thesis was the collection of data through interviews with Fijian and Kanak nationalist leaders, as well as Fijians and Kanaks not in leadership positions. ${ }^{62}$ These interviews focussed on gathering information on the role of ethnicity in politics and on Fijian and Kanak perspectives as to why ethnic affiliation is a political necessity. ${ }^{63}$ The information from these interviews, combined with other primary materials such as census data was fully integrated into the analysis of the paper.

This information was augmented by secondary sources reviewed from the Pacific Collection, Institute for Pacific Studies, and Centre for Development Studies at the University of the South Pacific, as well as the Centre culturel Tjibaou in New Caledonia, and other locations such as the Pacific Concerns Resource Centre (Suva, Fiji) and the FLNKS Offices (New Caledonia).

\subsection{Conclusion}

Allow me to concisely review the main theoretical points relating to my argument in this thesis. The politicisation of ethnicity is a question that has been examined by many theorists in many disciplines. One of the most interesting of these theories is the

62 Interviews included all of the leaders of the nationalist parties of the FLNKS coalition in New Caledonia, as well as, such prominent Fijian nationalists as Samisoni Speight, Col. Metuisela Mua, and Berenado Vunibobo.

63 For example, questions in Fiji included Fijian perceptions of Indians and vice versa, as well as leaders" statements on the causes of the 1987 and 2000 coups and the appropriate role for Fijian tradition in the state. In New Caledonia questions focussed on Kanak perceptions of grievance. 
'cultural conflict' theory of Crawford and Lipschutz. This theory is instrumentalist in that it emphasises the fluidity of ethnicity and the role that strategic choices play in politicisation. The core argument of the theory is that the politicisation of ethnicity occurs in cases of discrimination and disproportionate hardship. In other words, politicisation occurs when ethnicity becomes a criterion for the distribution of resources. This is a powerful argument but it fails in that it only accounts for some cases of politicisation. The politicisation of ethnicity occurs not only because of adversity and discrimination (defensive politicisation) but also when a group realises its political and economic possibilities (assertive politicisation). This is a more assertive form of politicisation that can occur without any perception of discrimination. What binds these two types of politicisation together is that they are propelled by a group's perceived lack of control. This perceived lack of control is rooted in such conditions as the distribution of political and economic resources, historical memory, demographics, and land rights. Furthermore, leaders and elites utilise ethnicity to acquire and maintain political power.

This thesis utilises the cases of Fiji and New Caledonia to examine the politicisation of ethnicity. These cases were chosen because, although the politicisation of the Kanaks in New Caledonia was driven by their marginalisation, the politicisation of the Fijians in Fiji occurred largely without such hardship. Therefore, contrary to the cultural conflict thesis of Crawford and Lipschutz, the politicisation of ethnicity is not only a result of discrimination but can also take the form of an assertive politicisation rooted in the political and economic possibilities of the nation.

The next chapter of this thesis will examine the politicisation of ethnicity over time in Fiji and New Caledonia (Chapter Two), whiles subsequent chapters deal with the 
continuing politicisation of ethnicity and contemporary ethnic politics (Chapters Three and Four), and the role of leaders and elites in the politicisation of ethnicity (Chapter Five). 


\section{Historical Analysis: The Politicisation of Ethnicity over Time in Fiji and New Caledonia}

\subsection{Introduction}

Politicised ethnicities cannot be separated from their historical context. The conditions necessary for the politicisation of ethnicity are created over time. ${ }^{1}$ Moreover, politicised groups generally possess some sort of historical memory or consciousness that contributes to their sense that they are distinct or that they have been discriminated against and marginalised from the state. This historical consciousness is one of the conditions that may contribute to a group's perceived lack of control and subsequently the politicisation of identity.

The state can have a profound impact on the politicisation of the groups within its borders. By its very nature the state has centralising tendencies and this imperative to centralise its control and power extends also to the management of identity. The form that politicisation will take is also influenced by the power of the state and the institutionalisation of identity through the state.

This chapter will compare and contrast the historical experience of the Fijians and Kanaks and how this relates to the politicisation of ethnicity. It will utilise the contributing factors for the politicisation of identity outlined in Chapter One (distribution of political resources, economic inequality, demographics, and land rights) as an

\footnotetext{
${ }^{1}$ As argued in Chapter I the politicisation of identity is fundamentally driven by a group's perceived lack of control. There are several conditions that help to create this perception including the distribution of political resources, the distribution of economic resources, demographics, land, historical consciousness, and inter-group competition.
} 
analytical framework to examine the emergence of politicised identities in Fiji and New Caledonia.

Both Fiji and New Caledonia had relatively fragmented identities in the precolonial period. The colonial state extensively reshaped ethnicity and created many of the conditions that have induced politicisation. The colonial interventions in Fiji and New Caledonia not only transformed the countries into multiethnic states but also stratified these ethnic groups. As this chapter will illustrate, the colonial experience of Fijians and Kanaks differed yet both groups became politicised. The politics of the postcolonial period have been largely shaped by the institutions and conditions inherited from the colonial state. Attempts to construct national identity have often been exclusionary and have further intensified ethnic polarisation. The politicisation of the Kanaks is defensive in nature and rooted in their historical marginalisation while Fijian politicisation is largely assertive as it developed mostly as a result of positive entitlements rather than historical (or contemporary) discrimination.

\subsection{Pre-Colonial New Caledonia}

An examination of conditions present in pre-colonial Fiji and New Caledonia is necessary to understand the impact of colonialism on the politicisation of ethnicity. In the era prior to colonialism there was no Fiji or New Caledonia, no political consciousness on that level. The Pacific was populated by successive waves of migration. The first peoples to land in Fiji and New Caledonia were the Austronesians who arrived around 2000bc. The rugged landscape of Grande Terre helped to define political institutions in pre-colonial New Caledonia where geography separated the population into 
many smaller tribal units, each speaking a different language. ${ }^{65}$ These tribal societies were further divided into clans and families. The tribes were loosely structured but each had their own political system, a close association with a particular land area, and often its own language. ${ }^{66}$ Identity in New Caledonia was fragmented with a lack of an overarching political space with an accompanying national identity.

Both clans and tribes were headed by a chief who had both a political and religious role and derived his legitimacy from the support of the people who, in turn, granted the chief respect and obedience. ${ }^{67}$ In theory the clan chief was the oldest male directly descended from the clan's founding couple. ${ }^{68}$ Pre-colonial societies in New Caledonia had a strong spiritual and economic connection to their land. The traditional economy was dominated by the cultivation of root crops, especially taro and yams. ${ }^{69}$ Clan members shared a sacred ancestral and territorial bond. ${ }^{70} \mathrm{Clans}$ were rooted in the notion of a particular area being the dwelling place of a common ancestor. All pieces of land were associated with particular gods; the mountains and forests were considered the

65 John Connell, New Caledonia or Kanaky, (Canberra: National Development Studies Centre, 1987) 8. New Caledonia's multilingualism has endured today with twenty-eight indigenous languages being spoken. In the pre-colonial era fission and fusion among the tribes was common.

${ }^{66}$ Connell 10 . It is imporsant to note that these tribes differ from the modern, colonially defined tribes. ${ }^{67}$ A council of advisors also supported each chief.

${ }^{68}$ Connell 11. Chiefs were given a certain amount of authority and the chicfly class often even spoke their own dialect. The tribes practised progeny where the eldest male son succeeded to chiefly title. The most powerful clan chief was the tribal chief (Great Chief).

${ }^{59}$ Connell 11. The distribution of these economic resources within tribal groups was fairly egalitarian. Inter-tribal trade was common as groups exchanged in order to obtain goods that were not available to them otherwise (ie. mountain peoples might trade taro for fish from coastal peoples. In Fiji, a similar type of trade occurred.

70 This idea of having a blood tie to the land is characteristic of many indigenous peoples in Melanesia and Oceania in general. 
abode of the ancestor. ${ }^{71}$ Moreover, each clan also had a "master of the land' who was the representative of the earliest inhabitants and had considerable power. ${ }^{72}$

In pre-colonial Melanesia "social territory coincided with natural territory."73 With this conception comes the belief that those who arrived on the land first (who can most closely trace themselves to the ancestor from that area) have greater rights that later arrivals, and society is arranged this way. ${ }^{74}$ This primordial attachment and claim to the land can have great implications for notions of inclusion, exclusion, and indigenousness. Throughout Melanesia's history there has been a constant tension between indigenous perceptions of 'belonging' to the land and attempts to construct national identities.

\subsection{Pre-Colonial Fii}

Pre-colonial Fiji had many similarities to pre-colonial New Caledonia. Two of these important similarities are the ancestral-land connection and importance of this connection for society as a whole, and the lack of an overarching national identity with accompanying political and economic institutions. However, power in Fiji was more

\footnotetext{
"Connell 10. This was true in both a mythical sense as well as a literal sense as the skulls of ancestors were often stored in caves on the mountainside.

${ }^{72}$ On Grande Terre the chief usually did not hold this position while in the Loyalty Islands he did. The societies of the Loyaliy Islands tended to be more influenced by Polynesian cultures and were therefore more hierarchical in nature with a greater scope for the exercise of chiefly power. On Grande Terre the division of power between the chief, the master of lands, and the council of advisors acted as limiting factors on the power of chiefs. Ultimately the authority of the chief was a function of individual leadership characteristics rather than their position.

${ }_{73}$ Connell 10. Anthropologist and Missionary Maurice Leenhardt said of the system "each group and clan has its own place. Each village and habitat has its place and each of the various parts reflects a particular function. The plan of society is written on the ground."

74. Conversation with anthropologist Michael Monsell-Davies, Samoa, July 2002. The absorption of individuals from other tribes was common in pre-colonial times but these individuals may not have the same rights as the native inhabitants.
} 
concentrated than in New Caledonia and the process of the consolidation of diverse groups into a new (national) identity had already begun in the pre-colonial era. ${ }^{75}$

The Fijian archipelago was a divided land with three major tribal confederacies (matanitu) struggling for power in the East: Rewa (Southeast of Viti Levu), Bau (Northeast Viti Levu), and Tongan-influenced Lau (the Lau Islands). ${ }^{76}$ Political rivalries were ruthless and cannibalism and warfare were widespread. Power was also fairly localised until the rise of Ratu Seru Cakobau, an aggressive Bauan chief who managed to conquer much of Eastern Fiji in the mid $19^{\text {th }}$ century. ${ }^{77}$ With Cakobau came greater centralisation and the Bauan dialect became the standardised version of the Fijian language. $^{78}$

The most basic unit of social organisation in Fiji was the mataqali. ${ }^{79}$ Much as in New Caledonia, each kinship group (mataqali) is descended from a common ancestor who lived in a particular place. There are also gods that are specific to each place. Thus, there is a territorial, kinship, and spiritual aspect to the mataqali and to Fijian social organisation. Mataqali were divided into sub-clans (castes) based on social functions. There were clans for fishermen, for farmers, for warriors, for priests, etc. ${ }^{80}$ Polynesian influences were stronger in Fiji than in the rest of Melanesia and authority was more often hereditary rather than the "big man" system of merit-based authority. The authority

\footnotetext{
${ }^{75}$ Fijians all spoke the same language (other than the Rotumans living on the Polynesian island of Rotuma in the north), but there were many locally-based dialects.

${ }^{76}$ Not long before the first arrival of the Wesleyan (Methodist) missionaries in 1835 there was a large Tongan migration and invasion. The Polynesians from the Vava'u Islands in Northern Tonga came in their great sailing canoes to the Lau Islands in Eastern Fiji. The Tongan presence in the Lau Islands left an indelible impact on that area and still has political ramifications today.

${ }^{77}$ Bau is a very small island off of the coast of Southeastern Viti Levu.

78 Nevertheless, even after the rise of Cakobau the westem part of Fiji (western Viti Levu) remained outside of the matanitu system and was instead divided into autonomous vanua

${ }^{79}$ Several mataqali together made up a yavusa (clan) and yavusa combined became vanua (states). Vanua aggregated into matanitu (confederations).
} 
of chiefs was also limited by their responsibility for good government and consensusbased decision making. ${ }^{81}$ As in New Caledonia, social and political organisation were fundamentally tied to land rights.

\subsection{Colonial New Caledonia: The Margimalisation of the Kanaks}

They [the Europeans] arrived in huge barques and they cut down our trees to fasten their sails to their boats. That was all right. They ate the yam. That was all right. But then they took the land, and the women and the young people... They must have been very unhappy in their own land to have come so far. ${ }^{82}$

The intervention of European colonialism in Fiji and New Caledonia had far-

reaching effects for ethnic identity in both places. ${ }^{83}$ Both experienced a massive influx of immigrants, which rapidly transformed them from being ethnically homogenous to heterogeneous. With this transformation the political landscape was forever altered. Existing groups were fused into new identities and political institutions were reshaped to meet the needs of the new central government. Moreover, ethnic competition became a political reality.

\footnotetext{
80 The top caste was the chiefly one, followed by the priests, then the warriors (bati), and so on. Social stratification was strongest in the more-Polynesian influenced Lau Islands.

${ }_{81}$ Nayacakolou, Leadership in Fiji, 42. Although Fijian social order is mostly ascribed, authority is dependent on being able to perform functions expected of your role. A line may die out or have its position 'usurped' if it loses its dominant position. Historically, individuals were sometimes adopted from other tribes and made chiefs. Chiefly title may also be displaced by internal uprising. An example of this was in the mid-eighteenth century when Ratu Seru (of Bau) became angry as he saw his father Ratu Tanoa marginalised and humiliated by the other chiefly families in Bau. He gathered support and launched a surprise attack burning Bau to the ground and killing his enemies. As a result, Ratu Seru became clan chief and Matanitu Chief (because his clan was dominant), earning the soon to be dreaded name Cakobau ("Bau bespoiled") in the process.

82 Connell 21. This is what Chief Daoumi of the Isle of Pines said to Louise Michel (a French communard imprisoned in New Caledonia) in 1885.

83 In 1774 British captain James Cook was the first European to sight the mountainous islands which he named New Caledonia due to their resemblance to Scotland (Caledonia in Latin).
} 
The colonial experiences of the Kanaks and Fijians also differed in significant ways. French colonial policy in New Caledonia marginalised the Kanaks from the economy and political system and sought to assimilate them into the French Empire through an influx of settlers. Kanak resistance to these policies has been strong and in fact, the anti-colonial struggle in New Caledonia has been more violent than anywhere else in the Pacific. In contrast, Fijians were relatively favoured and protected within the colonial system developed by the British. Despite these differences, both the Fijians and Kanaks became politicised.

As Europeans first began to trade with New Caledonia in the 1840 s, it had immediate impacts on Kanak society. Certain chiefs, such as the Naisilines on Maré, came to monopolise this trade and this led to a concentration of power. ${ }^{84}$ As the demand for foreign goods increased, access to these goods became a means to exercise power and the pre-colonial pattern of local self-sufficiency was destroyed..$^{85}$ During this period the first Christian missions were also established. The effects of the missionaries were enormous as Kanak culture was subordinated under French culture. ${ }^{86}$

The island territories comprising the political state of New Caledonia were acquired by France in $1853-65 .^{87}$ With the imposition of French colonial rule came the desire for the colonial state to consolidate its control through a system of indirect rule that

${ }^{84}$ Connell 21. Contact with the Europeans also brought extensive population movements as tribes moved out of the mountains and into coastal areas so as to be closer to the missions and trading posts. Trade also brought the introduction of tobacco, alcohol, and foreign diseases to the indigenous population. 85 Connell 25.

${ }_{36}$ Susan Ounei "For Kanak independence: The fight against French rule in New Caledonia," (Auckland: Labour Publishing Cooperative Society, 1985) 3. As the outspoken indépendentiste Ounei has tersely put it, "The struggle in New Caledonia has not just begun now. [It] began in 1853 when the French arrived and colonized our people. When they arrived they came with the Bible. The Bible was the beginning of our colonization. In their Bible it said never steal and never kill because God will be unhappy. While we believed in God, they massacred our people and stole our land. Now we end up with nothing but the Bible, and they have our land. That is the story of colonization in our country." 
emphasized the use of proxies and of traditional institutions. With this system of indirect rule also came the colonial imperative to unite diverse groups under a single administrative entity and to re-shape traditional institutions to meet the needs of colonial govemance. The governor selected a "Great Chief" for each district and a "Small Chief" for each tribe. ${ }^{88}$ Kanak identity was being re-imagined by the French.

A penal colony was established in 1864 . Thus the indigenous Kanaks found their new neighbours to be criminals deported from France. The use of New Caledonia as penal colony was the primary imperial interest in the early decades of French colonialism. Between the 1860 s and 1897 approximately twenty-two thousand convicts arrived in New Caledonia. ${ }^{89}$ Hostilities increased between Kanaks and French settlers, culminating in the revolt of 1878 .

The primary cause of the rebellion was European pressure on Kanak land. The rebellion was led by Chief Atai who petitioned the governor by bringing him two sacks and declaring, "this is what we had" (soil) and this is what you have left us with" (stones). ${ }^{90}$ Atai's rebellion was a guerrilla insurgency concentrated largely in the La Foa area. ${ }^{91}$ The French allied themselves with the foes of Atai and eventually subdued the

${ }^{87}$ Grande Terre was formally annexed by Napoleon II in 1853 and the lles Loyaute (Loyalty Islands) in 1864-5 (together with smaller outlying island dependencies).

${ }^{88}$ All of these chiefs were subject to the Service des Affairs Indigenènes and the local Gendarmes.

39 Robert Aldrich and John Connell, France's Overseas Frontier: Départements et Territoires D'Outre-Mer, (Hong Kong: Cambridge University Press, 1992) 101.

${ }_{90}$ Connell 58 . The immediate triggers for the revolt were both the roaming cattle of Europeans trampling Kanak crops and the murder of a European woman by tribesmen allied with Chief Atai. The French Governor responded to Chief Atai's concerns about European cattle trampling Kanak crops by telling him that the Kanaks should build fences around their land. Chief Atai responded "when my taro plants go eating his cattle, then I'll build fences!" By this point Kanaks were building fake huts in order to demonstrate their occupation of the land to meet European conceptions of land ownership.

${ }_{91}$ On the night of June 24 the revolt began. In the initial days of the conflict the rebels staged attacks on La Foa (including a police station) and Teremba. News of the attacks was rapidly telegraphed to Noumea and a force consisting of two hundred troops and a warship was dispatched. 
revolt. ${ }^{92}$ In total, one thousand Kanaks and two hundred Europeans died in the fighting. ${ }^{93}$ Although the 1878 revolt was regionally-based it did succeed in uniting many Kanaks in opposition to the French.

The French response to the revolt was the imposition of the "Indigènat" system which considered Kanaks to be beyond French common law, thus subject to repression and legal subordination. The Indigènat Code (1887) required Kanaks to provide free labour and prohibited them from living outside of their reservations (Kanaks were considered too primitive to become private landowners) without special permission. ${ }^{94}$ The code also barred Kanaks from carrying arms in European towns and forbid "sorcery", drunkenness, and nudity. ${ }^{95}$ The colonial state's systemic discrimination against Kanaks was increasing. Under Governor Feillet (1894) the number of French colonists greatly increased and 200000 hectares were stolen from Kanak landowners (between 1895 and 1901). ${ }^{96}$ Colonists also gave away free alcohol and sought to increase tribal divisions. At the end of the nineteenth century New Caledonia was characterized by frequent violent confrontations between settlers and the indigenous peoples.

After the 1878 rebellion the plantation economy collapsed and the nickel mining era began. With the collapse of the agricultural economy a stark economic inequality was emerging between the rural poor white farmers, and the large ranch owners and rich

\footnotetext{
92 Eventually other tribes joined the Dogny in their revolt including the tribes of Moindou, Ouatom, Poya, and Bourail. Most of the counter-insurgency fighting of the French was done by Kanaks.

${ }_{93}$ Aldrich and Connell 101. Of the survivors of Atai's tribe, six hundred were forced to settle elsewhere in Northern Grande Terre, six hundred were exiled to the penal colony on Isle des Pins, and three hundred were exiled to the Belep Islands. The French also destroyed villages and gardens and seized land. 94 Merle, I, "De l'idée de cantonnement à la constitution des réserves: la définition de la propriétée indigène," in Bensa, A. and I. Leblic (eds.), En Pays Kanak, Mission du Patrimoine ethnologique, Cahier 14, (Paris: Editions de la Maison des sciences de l'homme, 2000). A head tax was levied on Kanak landowners; the only way that the tax could be paid was through the provision of labour.

${ }_{95}$ Connell 71.

${ }^{96}$ Connell 71.
} 
colonist businessmen in Nouméa. Capital in New Caledonia was concentrated in the hands of a few powerful families such as Lafleur and Ballande. These families soon extended their dominance of economic life to political life.

French colonial policy in New Caledonia marginalized the Kanaks from the economy and political system and sought to assimilate them into the French Empire. Kanak marginalisation and resistance was increasing as the Kanak population declined while they were being overwhelmed by waves of French settlers. By the 1920s the Kanaks were a minority in New Caledonia as a whole, although certain regions - the northeast coast of Grand Terre, the Loyalty Islands, lle des Pins, and the Belep Islands still retained large Kanak majorities. ${ }^{97}$ The marginalisation of the Kanaks in their own land was nearing completion.

The colonial administration once again confronted Kanak resentment and resistance in the 1917 revolt. This uprising was concentrated in the Koné-Hienghène area and was essentially low-intensity guerrilla warfare. The revolt was put down by the colonial regime in a matter of months but was indicative of Kanak resentment of French rule. ${ }^{98}$ After the revolt, more land was confiscated and more villages were burned. ${ }^{99}$ All of this brutal suppression of the Kanaks came from a European world-view that sought to ascribe certain characteristics to the Kanaks. These characteristics were centred on the idea that the Kanaks were not of equal value to Europeans. ${ }^{100}$ This arose from the racialist and patemalistic ideology that the French imperial state held for subject

\footnotetext{
97 Connell 103

98 High estimates place the number of European dead at sixteen; there is no estimate of Kanak deaths.

99 Moreover, forty-five Kanaks were sentenced to hard labour, five were executed, five were imprisoned, and twenty were acquitted.

${ }_{100}$ Also among the assumptions of the French colonial state was that the Kanaks represented a somewhat monolithic and unified population.
} 
populations This "sense of racial and moral superiority was not confined only to missionaries; settlers from the lowest strata of European society "saw themselves as the heirs of a superior civilisation." 101

During the first hundred years of French colonial intervention in New Caledonia the Kanaks made a transition from being many separate groups living in relative isolation from the outside world to being consolidated into a single ethnicity (albeit one with many local variations). Moreover, nascent Kanak nationalism was emerging in response to French pressures. The cultural space of the Kanaks was becoming severely constricted and the Kanaks responded by politicising and uniting in opposition to French policies. ${ }^{102}$ This can be seen in both the 1878 and 1917 revolts against French rule. For the first time, the Kanaks were beginning to conceive of themselves as a unified group and the effects on New Caledonia would be far-reaching.

During World War II Kanaks were recruited into the French Pacific Battalion to fight in North Africa, Italy, and southern France. ${ }^{103}$ The war was also to have profound consequences for Kanak identity, as returning Kanak soldiers demanded increased political, economic, and social rights. In post-war New Caledonia Kanak politicisation increased as Kanaks began to articulate their national aspirations through political

101 Connell 77-78 and 104. The dark-skinned Kanaks (Melanesians) were also compared unfavourably with the light-skinned Polynesians. Also part of this doctrine of racial superiority was a characterisation of the Kanaks as "lazy" and "unreliable" as workers. One visitor wrote: "The tribes were all very dirty and lazy, and contented themselves with cultivating a patch of garden sufficient for the most meagre existence, and then spend the rest of their days lolling around in happy sloth. [The French Doctor] Ferron's explanation of this was that, when they were forbidden to go on their camnibalistic missions by the horrified missionaries they lost their zest for life, and became apathetic and lazy. He explained that had they been taught football, as the Maoris were, they would have retained their former strength and vitality, whereas now, with no interest in life, they were sliding fast downill."

102 Connell 85 and 113 . By 1903 nearly all Kanaks on Grande Terre were confined to reservations, When anthropologist Maurice Leenhardt met the chief of Canala (on the east coast) the chief said "just let me drink and die."

${ }_{103}$ New Caledonia itself was the location of a major US base and 150000 American troops were stationed there (giving name to the modern-day Noumea neighbourhoods of Receiving, and Motor Pool). . 
activism. During this same period French policy in New Caledonia has undergone many fluctuations, often corresponding with changes in government in France.

In 1946 the colonial status of New Caledonia was changed to overseas territory, and Kanaks were for the first time given French citizenship (although enfranchisement was still limited). The Union Calédonienne (UC) political party was formed in 1953 , inclusive of Kanaks, small landholders, union supporters, and some Catholic missionaries, under the slogan "deux couleurs, un peuple" ("two colours, one people"). The adoption of a pro-independence stance by the UC was a watershed in the politicisation of Kanaks. The party had originally been supported by broussards - poor white farmers, but after its declaration of this new platform many Europeans transferred their allegiance to parties opposing independence. ${ }^{104}$ The era of intense ethnic polarisation and competition had begun in New Caledonia. This competition was asymmetrical as the French commanded the instruments of political and economic power. Kanak gains within the political system were often met by changes to the rules instituted by the French colonial regime and its Caldoche allies. ${ }^{105}$ This only had the effect of further alienating and politicising the Kanaks as well as giving them incentives to seek extra-political remedies for their grievances.

Kanaks became further marginalised from the political institutions of New Caledonia when the provisions granted in 1958 for the decentralisation of power to regions (some of which were dominated by Kanaks) were scaled back during the

\footnotetext{
104 Moreover, almost all of the leaders of the independence movement (such as Jean-Marie Tjiabaou, Eloi Machoro, and Yeiwene Yeiwene) were Kanak with few exceptions.

${ }^{105}$ For instance, in the 1977 municipal elections pro-independence party Palika made gains on the east coast (Tjibaou also became mayor of Hienghène at this point). The French responded by taking municipal powers away from New Caledonia and centralising control in France.
} 
1960s. ${ }^{106}$ This had the effect of reinforcing the perceptions of many Kanaks that their political aspirations could not be realised in any form under French colonialism; as the Statute of Internal Autonomy deteriorated, younger Kanak protesters became increasingly radicalised, while older political organisations transformed to reflect the evolution in Kanak politicisation. ${ }^{107}$ In June 1975 the Union Multiraciale declared its support for independence; and two years later the UC followed suit.

Meanwhile, the fifties and sixties saw the development of nickel mining with the concomitant industrialisation of Nouméa. This would result in increasing prosperity as well as increasing Caldoches and Kanak resentment of "outside" French administration and business control. With the nickel boom of the 1970 s another major migration wave began with many economic migrants arriving in New Caledonia from other French possessions (such as Wallis and Futuna) as well as Europe. Aside from economic factors, there was a powerful political motivation for the French migration policy. This policy has deliberately sought to assimilate the Kanaks and destroy the nationalist movement through sheer force of numbers. The Kanak response to this perceived loss of control over their territory has been politicisation. Indigenous nationalist movements elsewhere in Melanesia would have a profound effect on Kanaks, who now became the only large Melanesian population still subject to colonialism. ${ }^{108}$

\footnotetext{
106 Nic Maclellan and Jean Chesneaux, France in the South Pacinc, (Melbourne: Ocean Press, 1998) 150. The constitution of the Fifth Republic offered the prospect of wide-ranging autonomy and was accepted by the Kanaks in a 1958 referendum. However, this autonomy was withdrawn when the powers of the Territorial Assembly were severely reduced in 1963 and again in 1969.

107 Maclellan and Chesneaux 155. Protests were led by the Foulards Rouges (Red Scarves) and Group 1878 (an organisation that favoured independence). 1878 was the year of Chief Atai's rebellion against the French. That an independence group would use this as its name is indicative of the historical consciousness that accompanies the Kanak nationalist movement.

${ }^{108}$ During the seventies independence movements in Melanesia resulted in independence for Fiji in 1970, Papua-New Guinea in 1975, the Solomon Islands in 1978, and Vanuatu in 1980.
} 


\subsection{Colonia Tini}

The presence of the British in Fiji had major effects on traditional society and its power structures. Many of the institutions now regarded as being the core of Fijian tradition (by the indigenous nationalists) were in fact, either created or heavily influenced by the British. Fijians often speak of the core of society as being the lotu (church), vanua (traditional society and the land), and matanitu (the state). The lotu was introduced (at times forcibly) by the British, and the vanua and matinitu were completely reshaped. These new conceptions of identity such as particular land title, the provincial system, the church, and the Great Council of Chiefs have all become an integral part of Fijian notions of self-identity and nationalist aspirations.

At the time of the first arrival of Europeans (mid $19^{\text {th }}$ century) Cakobau had begun to unite parts of Fiji under his rule. The British legitimated his position by naming him Tui Viti (King of Fiji), a position that did not exist in pre-colonial times. After many requests from Fijian chiefs, the British finally agreed to annex Fiji in $1874 .^{109}$ Cakobau had made a strategic political calculation that by converting to Christianity he could gain British support to entrench his own rule. Cakobau signed the Deed of Cession on 10 October 1874 (along with ten other chiefs). In annexing Fiji the British also utilised indirect rule by legitimating the power of chiefs. Moreover, they recognised that although they were assuming control, they were governing with the consent of the chiefs and holding the land in trusteeship for indigenous Fijians. ${ }^{110}$ Kaplan and Kelly argue:

The theme of priority for state paternalistic protection of indigenous Fijians, a commitment allegedly springing from the 1874 Deed of

${ }^{109}$ Kaplan and Kelly 160.

110 Although the British and Fijian chiefs established a kind of partnership, there can be no doubt that the Fijians were the junior partners. 
Cession...runs very deeply in Fiji's colonial history. It was often used to maintain colonial state power against the political aspirations of white settlers and, increasingly in the twentieth century, those of Indo-Fijians. ${ }^{11}$

The British colonial state had a major impact on the politicisation of both Fijian and Indian identity. There was a significant variance, however, in the perceptions and policies which the British extended to these groups. The Fijians were viewed as being the rightful rulers of Fiji and a backward group that was in need of paternalistic protection. On the other hand, the Indians were viewed as a group that was a threat not only to the colonial government but also Fijian sovereignty. The distinct treatment that the British extended to each group reinforced ethnic divisions.

The British not only imposed colonial political constructs on Fiji but also reinvented Fijian traditional institutions to meet the governance needs of the colonial state. The British sought to co-opt the chiefs and use them for indirect rule by creating a Native Council to advise them on matters of importance to the indigenous people. This council brought together all of the major chiefs of Fiji in a manner that had not been done in the pre-colonial era. The British also created an administrative system that reinforced and utilised the power of chiefs (see Appendix). The British institutionalised and established traditional order and land rights through the Native Lands Commission (NLC) under Wikinson in the 1890s and Maxwell after 1910. There were significant problems with the NLC's approach to examining land claims. ${ }^{112}$

\footnotetext{
11! Kaplan and Kelly $207-208$.

R.R. Nayacakalou, Leadership in Fiji, (Suva, Fiji: Institute of Pacific Studies, 1975) 9 and 13. Professor Cyril Belshaw argues, "I do not know what criteria the Maxwell Commission used to establish whether such and such a social unit was a mataqali or i tokatoka or yavusa. The decision is not clear-cut at all...the system was one of bifurcation and amalgamation in response to the pressures of population and the ambitions of powerful or weakening men. Only those who have need to watch the legalities of the administration give the correct answers assuredly; they have been reading the records." Today two parallel sets of classification exist: 1) classification according to the commission, and 2) socio-political organisation
} 
The most significant political development during the colonial period was the mass immigration of the Indians to Fiji, which forever altered the nature of identity in the archipelago. Within a generation Fiji moved from being a relatively homogenous territory to being ethnically heterogeneous. Between 1879 and 1916, 60595 Indians were brought to Fiji by the British to serve as indentured labour for the emerging sugar industry. ${ }^{113}$ Ethnicity, religion, place of origin, and language divided these migrants, but the colonial experience united them. ${ }^{114}$

The British spoke of Fiji as being a "three-legged stool" with the British providing capital and administrative expertise, the Fijians land, and the Indians labour. ${ }^{115}$ Thus, the British colonial policy sought to stratify ethnicity. This economic relevance of ethnicity is precisely the condition that Crawford described as being conducive to politicisation.

The ethnic division of labour was soon to be disturbed by the arrival of free economic migrants (mainly from Gujarat and Punjab). These migrants moved rapidly into the retail sector, disturbing British dominance there. Another perceived Indian challenge to British hegemony in Fiji was the emergence of Indians as plantation owners. ${ }^{116}$ The European settlers, threatened by the loss of their monopoly over commerce, began to project Indians as being a threat to Fijians and stirred up racist

as it exists on the ground. There are still many who allege that records were falsified for the land commissions in order to increase the position of certain individuals and groups.

113 Robertson and Sutherland 61 . The British had followed the same policy in such other colonies as Trinidad, Malaysia, and Guyana. Indian indentured labourers were given the choice of returning after five years (though they would have to work five more to earn free passage) but most chose to remain in Fiji.

114 These migrants came from all over India but especially Uttar Pradesh and Tamil Nadu.

115 The first Indian migrants were very poor and quietly assumed their assigned position as a sort of permanent underclass that existed only to provide cheap labour for the economy.

${ }_{116}$ The Colonial Sugar Refinery (CSR) company wanted to concentrate its milling but was not getting enough of a supply of harvested cane from the Europeans, so it began to set up its own plantations. In 1894 
sentiment. In 1922, European hotel owner J.J. Ragg wrote a letter to a chief advising that he should "endeavour to permeate the whole of the Fijian race with the fixed idea that the granting of the franchise and equal status to the Indians in Fiji would mean the ullimate loss of all their land and rights, and later their final extinction from the face of the earth." 117 The British not only institutionalised economic power but also sought to encourage ethnic divisions in order to reinforce their position.

During the early period of Indian migration Fijians were repeatedly assured that the numbers of migrants would be relatively small. Despite these assurances the presence of the Indian population in Fiji continued to increase and by 1946 the Indian population was in the majority and growing at a rate faster than that of the Fijians. ${ }^{118}$ Indians remained the majority of the population until the mass emigration that followed the 1987 coup. The demographic dominance of the Indians contributed to Fijian fears of a loss of control over their country and therefore to the defensive aspects of Fijian politicisation.

As Indian economic migrants arrived in Fiji and improved their economic position vis à vis other groups, they called for greater political equality. ${ }^{119}$ The British settlers in Fiji were alarmed that the rising nationalist demands among the Indo-Fijians were starting to disturb the economic, social, and political hierarchy instituted by the colonial government. During one Legislative Council debate on 16 July 1946 European businessman A.A. Ragg tabled a motion that stated:

it began leasing small plots of land to Indians who had completed their indenture. A strong anti-Indian sentiment emerged among European planters who saw the Indians as competitors.

${ }_{117}$ Robertson and Sutherland 65.

${ }_{118}$ Robertson and Sutherland 65 . In 1911 Fijians were $62 \%$ of the population and Indians were $29 \%$; in 1936 Fijians had dropped to being only $50 \%$ of the population and Indians had risen to be $43 \%$.

119 The independence movement in India led by Gandhi also began to influence Indo-Fijians to call for greater political independence. Gandhi even dispatched lawyers to Fiji to act as advocates for Indo-Fijians. 
That in the opinion of this Council the time has arrived - in view of the great increase in the non-Fijian inhabitants and its consequential political development - to emphasise the terms of the Deed of Cession guarantee given that Fiji is to be preserved and kept as a Fijian country for all time... The duty of trusteeship devolves upon Europeans and in this duty the Indians have no part. ${ }^{120}$

A Fijian chief who was a council member responded to Ragg's call by speaking of the "colossus of Indian domination" in Fiji. ${ }^{121}$ Indian commitment to the political community was being questioned at the same time that Indians were being told that they could never be anything but secondary citizens. ${ }^{122}$ Fiji was building its national identity around the notion of 'Fijianness.' 123

During the $1960^{\circ}$ s, Europeans and Fijians formed an ethnic alliance to resist repeated Indian demands for a common electoral roll in Fiji. ${ }^{124}$ As second and third generation Indians emerged as a political force in Fiji, Fijian nationalism also emerged. Clearly the presence of the Indians in Fiji played a role in Fijian perceptions of marginalisation and Fijian politicisation. Yet the colonial system actually favoured the Fijians over the Indians; so it is very difficult to argue that Fijian politicisation emerged as a result of adversity or discrimination. Much of the impetus for independence came from Indian leaders and many Fijians were not in favour of independence in 1970 as they felt that it would also entail a loss of Fijian paramountcy (which was protected by the

\footnotetext{
120 Robertson and Sutherland 66.

${ }^{121}$ Roberston and Sutheriand 66.

122 Asesela Ravuvu, The Facade of Democracy, (Suva, Fiji: Reader Publishing House, 1995). See also Kaplan and Kelly. During the Second World War, Indians were often accused of nor shouldering their share of the war burden, especially relative to the contribution of Fijian soldiers.

${ }^{123}$ One example of this institutionalisation of Fijian identity in the state was the Fijian administration which was supposed to be temporary but came to be seen as a guarantor of the rights of the Fijian people (and a recourse to correct Fijian's perceived power imbalance).

${ }_{124}$ The Federation Party (later National Federation Party or NFP) emerged as the voice of the Indo-Fijian cane farmers. The Fijian Association Party also was formed and quickly allied itself with anti-NFP forces in the Indian community at the August 1965 Constitutional Conference. This was significant because it was the beginning of a long history in Fiji of multi-racial alliances based on mutual class interests. This political alignment led to the formation of the Alliance Party in March of 1966.
} 
British). ${ }^{125}$ As leading Fijian nationalist Asesela Ravuvu described it: "they [Fijians] denounced Common Roll and political independence which the NFP had been advocating, and strongly reaffirmed their link with the British Crown." 126 In fact, Fijians have always resented the Indian presence in Fiji as being antithetical to their national aspirations. This is the fundamental motive for Fijian politicisation, not hardship or discrimination. The following chart compares the politicisation of the Kanaks and Fijians through the pre-colonial and colonial periods and how specific factors contributed to that politicisation:

Figure 2.1 Ethnicity and Ethnic Politics in Pre-Colonial and Colonial Fiji and New Caledonia

\begin{tabular}{|l|l|l|l|l|}
\hline & $\begin{array}{l}\text { Distribution of } \\
\text { Political Power }\end{array}$ & $\begin{array}{l}\text { Economic } \\
\text { Inequality and } \\
\text { Poverty }\end{array}$ & Land Rights & Demographics \\
\hline $\begin{array}{l}\text { Fre-Colonial } \\
\text { Fiji and New }\end{array}$ & $\begin{array}{l}\text { Mono-ethnic } \\
\text { territory with } \\
\text { localised identity } \\
\text { and power } \rightarrow \text { Iack } \\
\text { of inter-ethnic } \\
\text { competition }\end{array}$ & $\begin{array}{l}\text { Ethnic } \\
\text { homogeneity } \rightarrow \\
\text { lack of inter-ethnic } \\
\text { competition }\end{array}$ & $\begin{array}{l}\text { Ethnic } \\
\text { homogeneity } \rightarrow \\
\text { lack of inter-ethnic } \\
\text { competition }\end{array}$ & $\begin{array}{l}\text { Ethnically } \\
\text { homogenous }\end{array}$ \\
\hline $\begin{array}{l}\text { Colonial New } \\
\text { Caledonia }\end{array}$ & $\begin{array}{l}\text { Kanak } \\
\text { marginalisation } \\
\text { through } \\
\text { discriminatory } \\
\text { policies such as the } \\
\text { Indigènat Code }\end{array}$ & $\begin{array}{l}\text { French control } \\
\text { extraction and } \\
\text { distribution of } \\
\text { resources } \rightarrow \\
\text { Kanaks } \\
\text { impoverished }\end{array}$ & $\begin{array}{l}\text { French colonists } \\
\text { seize Kanak land }\end{array}$ & $\begin{array}{l}\text { Waves of French } \\
\text { settlers reduced } \\
\text { Kanaks to plurality }\end{array}$ \\
\hline $\begin{array}{l}\text { British reinforce } \\
\text { institional Fijian } \\
\text { form ethnic } \\
\text { alliance with } \\
\text { Fijians }\end{array}$ & $\begin{array}{l}\text { Fijians provide } \\
\text { land, Indians } \\
\text { labour, and } \\
\text { Europeans capital. } \\
\text { Europeans receive } \\
\text { most of the } \\
\text { benefits }\end{array}$ & $\begin{array}{l}\text { Fijians retain } \\
\text { control over vast } \\
\text { majority of land }\end{array}$ & $\begin{array}{l}\text { British } \\
\text { introduction of } \\
\text { Indians eventually } \\
\text { reduces Fijians to } \\
\text { minority }\end{array}$ \\
\hline
\end{tabular}

125 Kaplan and Kelly 174.

126 Ravuru, The Facade..., 54. 


\subsection{Les Twénements: the Kamak challenge to the Colonial State in New Caledonia}

We want to proclaim our cultural existence... we are not escapees from prehistory; still less are we archaeological artefacts...Today, Kanaké comes to you, laden with years and with history, rich with a unique cultural experience. It is claiming its place in the sun. ${ }^{127}$ - Jean-Marie Tjibaou

Les Evénements ("the events" 1984-1988) was the most violent period in New Caledonia's colonial history. It represented the moment when Kanak nationalism reached its zenith and met the immovable French State, with explosive results.

The movement for total independence began in 1975, led by UMNC (Union Multiraciale Nouvelle Calédonienne). The UC avocation of just limited autonomy now seemed inadequate. In France the socialist party of Mitterrand had been supportive of auto-détermination (autonomy and self-determination), but when elected as the national government in 1981 the party proceeded with more cautious policies. By the beginning of the 1980s Kanak frustration was growing and Kanaks began to aggressively assert their land claims by illegally occupying vacant land.

Pro-independence parties in New Caledonia, including FULK (Front Uni de Libération Kanak), PALIKA (Parti de Libération Kanak), and UC, collaborated in 1984 in forming the Front de Libération Nationale Kanak et Socialiste/Kanak Socialist National Liberation Front (FLNKS), with the former UC president, Jean-Marie Tjibaou, a Kanak, as its first leader. The FLNKS included five political parties, a trade union, a feminist group, and activists from the churches, land rights movements, and others in the NGO community. The UC remained the largest and dominant political force in the

\footnotetext{
127 Maclellan and Chesneaux 154.
} 
FLNKS. ${ }^{128}$ The FLNKS opposed the Lemoine Statute because it meant that there would

be no referendum on independence for at least five years, there were no definite electoral

reforms, and it was thought by the FLNKS to reinforce the position of the Kanaks as a

minority within New Caledonia. ${ }^{129}$

With both the FLNKS and French pursuing militant confrontational tactics, Les

Evénements were characterised by intense racial provocation between pro-independence

Kanaks and Europeans. ${ }^{130}$ The Tiendanite Massacre (December $5^{\text {th }} 1984$ ) was both an

${ }_{128}$ Connell 265; Maclellan and Chesneaux 160.

129 Nic Maclellan and Jacques Sarimin Boengkih, "France's Decolonization Process in New

Caledonia: Conflict on the Path to Self-Determination," Australia-Pacific Community Nework, Centre for

Asia-Pacific Studies, Victoria University, Pacific Series, Working Paper no. 1 (1998) 6. See also Ounei 89. The FLNKS Charter declared that French government declarations on the innate and active Kanak right to independence have effectively not been put into practice; that government is directly threatening Kanak people with the prospect of disappearing by decisively making them a minority in their own land; and that government prevents Kanak control over and full participation in the economy. Therefore, in keeping with United Nations declarations, Kanaks claim the right "to be considered as the only legitimate people in the Kanak land and to have there their own homeland", the right "to obtain restoration of all the lands so as to set up the Kanak country as an integral whole", the right to "their own sovereignty which will allow then to freely choose their political system - Kanak and socialist independence", and - interestingly - the right "to welcome the non-Kanaks."

${ }^{130}$ Before Les Evénements competition between the Europeans and Kanaks had been relatively free of violence. Kanaks were increasingly feeling alienated from the French state. Kanak nationalist hopes, raised with the 1981 election of François Mitterrand were dashed when on September 19, 1981 UC Secretary Pierre Declerq was assassinated. Kanak militants responded by blockading roads, taking an Australian tourist family hostage, and setting off a bomb in Nouméa. The escalating cycle of violence was accompanied by escalating thetoric on both sides and the hardening of positions. Moreover, an abundance of small arms exacerbated the overall security situation. In November 1984, FLNKS organised an "active boycott" of the New Caledonian elections. This was really the beginning of Les Evénements as violence was transformed from sporadic to sustained. The active boycott took on violent dimensions as roads were barricaded, houses burnt down, and land occupied. In one of the famous images of the boycott, UC Secretary Eloi Machoro was photographed smashing a ballot box with an axe. Insurrection was almost reaching a point of guerrilla war and Europeans began to flee the towns of the east coast. In December 1984 , a Provisional Govemment of Kanaky was declared and a flag was adopted. The next four years were characterised by occupations of economic and government institutions, isolated attacks, roadblocks, arson, and clashes between settlers, FLNKS, and the French State. The French Army was brought in to "solve" the problem and New Caledonia became a heavily militarised area; eight thousand police and troops were deployed in rural areas around the territory in small mobile units. This policy was known as nomadisation and was intended to help quell resistance to French rule, but it only succeeded in fuelling the escalating cycle of violence and feelings of insecurity on both sides. There were also many attempts at conflict resolution in this period including the Pasani and Fabius Plans, the Pons Statute, and the Matignon and Oudinot Accords. Later in 1984 Kanak militant Eloi Machoro seized control of the Gendarmerie in Thio. The events in Thio were eventually resolved relatively peacefully but Machoro was to pay for his attack on the French State with his life less than a year later. After the Tiendanite massacre (1984) violence continued to escalate. Between November 13 and December 31, 1984, one hundred seven road blocks were erected, ninety-six buildings and cars were destroyed by arson, fifteen bomb explosions occurred, and 
example of such provocation and violence and a landmark event in the development of Kanak nationalism. The massacre transpired when settlers ambushed and massacred ten Kanaks (including two of Tjibaou's brothers) in the Hienghène Valley near Tiendanite. ${ }^{131}$

The FLNKS began to gamer some international support for its cause in the United Nations, the Non-aligned Movement, and neighbouring states. The French were not moved by all of this condemnation and non-violent Kanak demonstrations were often met with a brutal response from the police. In 1985 a planned referendum on self-government in association with France was rejected by the independence movement as being inadequate; however a very short-lived program of land reform and limited autonomy was initiated by the territorial government anyway. In May 1986 the new conservative minister for New Caledonia announced a plan which decreased autonomy for the four regional councils and abolished the lands office which had been charged with obtaining land for Kanaks. At this point the South Pacific Forum (the international organization based in Fiji representing the independent states of the South Pacific together with Australia and New Zealand) officially decided to back Kanak self-determination.

An independence referendum was finally held in Sept. 1987; however it was boycotted by a large proportion (some $84 \%$ ) of eligible Kanaks, so of the $59 \%$ of total New Caledonian voters who did vote, $98 \%$ were opposed to independence. The lines of ethnic voting were clearly drawn, with virtually all French, Polynesians, and other ethnic groups opposed, while a high proportion of Kanaks were supporters. The FLNKS held

sixteen people were killed. Many of the communities in la brousse became ghost towns as over two thousand people fled rural areas for the relative safety of Nouméa.

131 Tjibaou's brothers had earned the hostility of local settlers by aggressively pressing land claims. 
that the only eligible voters should be Kanaks and New Caledonian-born with at least one parent also bom in New Caledonia; this position was backed by a UN resolution.

In 1988, frustrated by repeated rejection of their proposals, the FLNKS announced a "muscular mobilisation" campaign. In April 1988 on Ouvéa, one of the Loyalty Islands, militants attacked the police station, four gendarmes were killed and others held hostage in a cave near Gossanah village. French commandos were dispatched and when they reached Gossanah they tortured the villagers to gain information as to the location of the hostages. ${ }^{132}$ Djubelli Wea, a Protestant theology student and independence activist was dragged from his sick bed, questioned, and tied to a tree. ${ }^{133}$ His father was severely beaten by French troops and later died. ${ }^{134}$ When the French commandos stormed the caves nineteen Kanaks were killed. The Island of Ouvéa had been devastated. Men from over half of its twenty-seven communities were either dead or in jail.

In June 1988 the Accords de Matignon were signed by Tjibaou and Jacques Lafleur, leader of the ruling Rassemblement pour la Calédonie dans la République/Rally for a New Caledonia within the French Republic (RPCR). The Matingon Accord included provisions for a 1998 referendum on independence, increasing autonomy, the 'rebalancing' of development, and amnesties for prisoners. New Caledonia was divided into three provinces (North, South, and the Loyalty Islands) which had responsibility for primary education and health services. A referendum was held in New Caledonia $-55 \%$

\footnotetext{
132 Maclellan and Chesneaux 166. I received the same accounts in my discussions with local villagers in August 2002.

1.33 Maclellan and Chesneaux 166.

134 Maclellan and Chesneaux 166.
} 
voted in favour with most of the "no" votes coming from majority European areas." But with feelings still running high, in May 1989 Tjibaou was assassinated by Djubelli Wea on Ouvéa while attending a Kanak gathering intended to mark the end of the mourning period - local Kanaks felt he had compromised too much with the government.

In 1998 the Matingon Accord was succeeded by the Nouméa Accords. A referendum on independence was to be delayed for fifteen to twenty years, with the French granting New Caledonia progressively greater autonomy. The accords also changed New Caledonia's constitutional status from being an Overseas Territory to being a "Special Territorial Entity." With the Nouméa Accords New Caledonia seems to gradually be making the transition to full independence. In the interests of reconciliation the accord also re-examined the historical legacy of colonialism and contained provisions for the teaching of Kanak languages in schools, as well as the choice of common symbols such as a name for the country and flag.

Over the past sixty years Kanak identity has transformed from being a somewhat sporadic and loose resistance to French rule (with an accompanying sense of being Kanak) to an organised nationalist movement, supported by most Kanaks, with the goal an independent 'Kanaky.' Maclellan and Chesneaux write:

The development of a truly Kanak political consciousness took place gradually. The desire to preserve customary values (attachment to the land, the rules of collective life, the strength of ancestral cultural experience), were carried through borrowings from Christianity (the dignity of the human person) and French Republican values (liberty and equality, human rights and social rights). ${ }^{136}$

135 A referendum was also held in France and the Overseas Territories and Départments with $80 \%$ voting in favour of the Accord.

136 Maclellan and Chesneaux 153 . The influence of French radicals (some Kanaks in later years were to attend university in France) and third world anti-colonial movements were also important in the 
The resurgence of Kanak identity was a cultural phenomenon before it was political. ${ }^{137}$

Kanak nationalism also had social and economic dimensions as Kanak nationalists

created independent institutions such as media outlets, Kanak popular schools (Ecoles

Populaire Kanak, or EPK's), and local co-operatives. ${ }^{138}$

The future status of New Caledonia is not only a question of political structure but of the very identity that the citizens of New Caledonia will assume. Will an independent New Caledonia be Kanaky, a Kanak homeland? Will it remain a part of France? Or will it become an independent state founded on the principles of multiculturalism and citizenship? With the Matignon and Nouméa Accords reconciliation has become the political order of the day. Consequently there is a movement within New Caledonia to establish a new "Caledonian" identity that includes all of the peoples of New Caledonia, an identity which emphasises shared citizenship over cultural differences. ${ }^{139}$

\subsection{Fivian Politicisation and Nationalism in the Post-Colonial Period}

Since independence in 1970 much of the political struggle in Fiji has revolved around the identity of the post-colonial state. Fijian nationalists have sought to build a

development of a Kanak nationalism. As all of the surrounding Melanesian countries were gaining their independence the Kanaks remained a minority in their own land, living as French colonial subjects.

137 One crucial even in the evolution of Kanak nationalism was the Melanesia 2000 Festival in Noumea in 1975. The festival was organised by a young Kanak cultural leader (and mayor of Hienghène) named Jean Marie Tjbaou. Melanesia 2000 was a cultural landmark and signal to the world that Kanals were a nation with a proud cultural tradition. Another example of the relationship between Kanak culture and nationalism is Kaneka music: a blend of Kanak mythms, rock, and reggae with lyrics about Kanak pride and resistance. Many of the best known of these bands such as Gurujele and Mexem have strong political messages 138 The EPK's taught children the history and the languages of Kanaky (Kanak New Caledonia). Parents who chose to send their children to the EPK's were ineligible for government subsidies. All of the EPK's (except one in Ouvéa) have now closed as the number of students fell and some were destroyed in the 1988. New media institutions included the magazine Bwenado and Radio Djiido in Nouméa. The other stations Kenu and Mara were established in La Brousse and the Islands. Bwenado and other radio stations no longer exist today but Radio Djiido continues to operate. 
state based on their conception of tradition and the principle of Fijian paramountcy while Indians have generally sought a state based on shared citizenship. Fijian politicisation is partially defensive in the sense that it is driven by a feared loss of Fijian political control to Indians. However, rather than any form of real or perceived marginalisation, Fijian nationalism is grounded in Fijians' fundamental sense of what the state of Fiji ought to be (positive entitlements).

In the post-colonial period the distribution of economic resources by the government continued to be ethnically determined. ${ }^{140}$ In a 1982 recession the Fijian economy shrunk by $1.1 \%$. With economic recession resources become more scarce and Indian visibility in the retail sector likely increased Fijian resentment and fuelled the nationalist movement. ${ }^{141}$

Over time communalism has increased in Fiji and this has been reflected in both electoral results and political thetoric. Fijians have increasingly sought to assert their ownership of their political space at the same time that Indians were seeking to secure their status. Since independence, every time that Fijian paramountcy has been challenged through electoral results, Fijian nationalists have intervened to restore their control.

139 Pascale Bernut-Deplanque, Lidentité Culturelle Calédonienne: Construire Possible Ou Utopie? (Nouméa: lle de Lumière, 2002) 175.

${ }^{140}$ For example, in response to nationalist demands the Fijian government established a program making it easier for Fijians to gain entrance to the University of the South Pacific.

${ }_{14 !}$ Robertson and Sutherland 80 . The Indian-dominated Fiji Labour Party was also created as a result of cuts to the public sector. The FLP was unique in that rather than being an ethnic party in coalition with parties from other ethnic groups, its support base was more class-oriented. The first party President Dr. Timoci Bavadra (a Fijian from Viseisei Village in the west, who was not a high chief) argued: "we recognised that it was time for the working people of Fiji to form their own political party rather than continue to rely on the goodwill of existing political parties that increasingly had demonstrated that they represent only the narrowest interests." 
The first example of this occurred during the April 1977 elections when the Indian-dominated NFP won 26 seats - a majority government by only two seats. ${ }^{142}$ It was the first time that a predominately Indian government had been elected. However, divisions within the NFP prevented it from quickly forming the government. Ratu Sir George Cakobau, Governor General and Vunivalu (paramount chief) of Bau, appointed Ratu Mara to an interim government until new elections could be held. It was essentially a bloodless coup by the Fijian establishment, which rejected what they perceived as an Indian challenge to their hegemony. In the elections held later that year ethnic polarisation increased as Fijians, fearing another Indian victory, rallied around the Alliance Party, which won a massive majority of twenty-one seats. ${ }^{143}$

The second time that Fijian nationalists intervened to prevent what they perceived as a loss of Fijian control was in 1987 when Labour won the elections under the leadership of Timoci Bavadra (a Fijian). The FLP was thought by many Fijians to be an Indian-dominated party and Bavadra had a predominately Indian cabinet. ${ }^{144}$ As one Fijian recounted to me, "when we found out that Labour won we [Fijians] got a sick feeling in our hearts. I know that it sounds bad but it's true." ${ }^{\text {145 }}$ Bavadra was portrayed as being a figurehead for Indian domination. On April 51987100000 Fijians marched in

\footnotetext{
${ }^{142}$ The Alliance Party won 22, and Butadroka and the western united front leader Ratu Osea Gavidi won the other two. Overall support for the Alliance among Fijians had decreased by $19 \%$.

${ }_{143}$ The Alliance attacked the Fijian nationalist parties during the campaign and exploited divisions in the NFP. In the next elections in 1982 the Alliance majority decreased to four seats due to Fijian disaffection with its policies.

144 While it is accurate that much of the support that the FLP received was from Indians, it also had the support of many urban Fijians. However, the FLP won in a coalition with the NFP, an almost entirely Indian party (led by Jai Ram Reddy).

${ }^{145}$ Conversation with Taliai Rasolo, Suva Fiji, September 2002.
} 
the streets of Suva demanding a return to Fijian rule. ${ }^{146}$ Bavadra's victory represented the loss of political control for many Fijians.

One Fijian who was concerned with the election results was a young Fiji Army Colonel named Sitiveni Rabuka. In May 1987 Rabuka staged a military coup in the name of the Taukei (Fijians). Rabuka had the support of the chiefs, the church, and the military - pillars of Fijian society - in the coup. In December, Prime Minister Ratu Mara and Governor General Ratu Penaia Ganilau (an eastern high chief) determined that Fiji needed a government of national unity. At this point, Rabuka staged a second coup, and declared Fiji a republic. The SVT party was created after the coup in order to be the "party of the chiefs" and to reinforce chiefly power.

In 1990 Rabuka completed his 'Taukei revolution' by promulgating a highly racist constitution. The 1990 constitution declared that no Indian could ever hold the posts of president or prime minister and gave Fijians a disproportionate share of electoral power. ${ }^{147}$ The committee that drafted the 1990 constitution was essentially made up of supporters of the coup and enjoyed little legitimacy amongst Indo-Fijians. ${ }^{148}$ The coup also received nearly universal international condemnation. ${ }^{149}$ The 1987 coup was a strong victory for the Fijian nationalists. Fijian control over government institutions was reestablished (if it had ever been lost in the first place).

\footnotetext{
${ }^{146}$ Asesela Ravuvu, The Facade of Democracy 80 . One placard at the march expressed the feelings of many Fijians, "Reddy gun, Bavadra bullet."

147 The constitution also allocated thirty-two of the thirty-seven Fijian communal seats on a provincial basis. This reinforced the electoral inequalities between rural and urban Fiji and illustrated that the nationalist's conceptions of Fijian identity and tradition was rooted in the village.

148 Martin Doombos and A. Haroon Akram-Lodhi, "Introduction: Confronting the future, confronting the past," in Confronting Fiji Futures, Haroon Akram-Lodhi (ed.), (Canberra: Asia Pacific Press, 2000) 25. 149 Some countries in Oceania indicated their sympathies lay with the coup as an instrument of indigenous empowerment. The coup was damaging to Fiji's international reputation and resulted in Fiji being expelled from the Commonwealth.
} 
Before the 1987 coups many Fijians felt threatened by their weakening demographic position in the country. After the coup a fundamental demographic shift took place as many thousands of Indians left the country and Fijians were once again in the majority. This emigration was one of the most important legacies of the coup. The ethnic balance of power in Fiji was forever altered and Fijian control was incontestable.

A few years after the coup Rabuka became a proponent of multi-racialism, and worked for the creation of a new, more moderate constitution. ${ }^{150}$ The 1997 Constitution reduced the number of communal seats and allowed Indians to take an important political position in the country while protecting Fijian paramountcy through land ownership and the ability to control the Senate (and by extension, the Presidency).

Rabuka was not rewarded for his efforts at constitutional reform and the SVT suffered a stunning electoral defeat in the 1999 elections. The Fijian vote had been divided and labour won a thirty-seven seat majority and two-thirds of the seats in the House through its People's Coalition. Mahendra Chaudhry became the first Indian prime minister of Fiji. Under the 1997 Constitution any party with $10 \%$ of the vote is entitled to three cabinet seats; the SVT wanted four specific posts, Chaudhry refused and excluded the SVT from government. This was a failure of leadership. There were many Fijians who were uneasy about what they interpreted as the loss of political control over their country again and Chaudhry needed to make significant concessions to calm these fears.

Rabuka did not challenge Chaudhry's rejection of the SVT power-sharing proposal but resigned from politics and became the chair of the Great Council of Chiefs.

\footnotetext{
150 The Reeves Commission was created to take submissions and draft the new constitution.
} 
His replacement Ratu Inoke Kubuabola was more militant. ${ }^{151}$ Kubuabola planned to exploit divisions and link up with disenchanted members of the People's Coalition government such as the Party of National Unity (PANU), Veitokani ni Leweni Vanua Vakaristo Party (VLV), and the Fijian Association Party (FAP). ${ }^{152}$

Chaudhry undertook an aggressive legislative agenda that "tackled too many wellentrenched interests too quickly., ${ }^{, 153}$ He also disbanded the Fiji Intelligence Service and refused to renew Police Commissioner Isikia Savua's contract beyond two years. The Chaudhry government failed in the manner in which they presented these policies to the public. ${ }^{154}$ Their economic policies further alienated some Fijian leaders. An example of this is the mahogany portfolio. Fiji has 52000 hectares of plantation mahogany (these are the largest reserves in the world and are valued at between FJ\$136-500 million). ${ }^{155}$ The FLP alienated and angered the chiefs by failing to consult with them over plans for milling the mahogany. Moreover, there were certain elements of the Fijian elite (including George Speight) who stood to "profit from their links to one particular processing tenderer." 156

${ }^{151}$ Kubuabola was one of the founders of the Tuakei movement. Jone Dakavula, an SVT campaign coordinator was present at the first SVT meeting after the election. According to Dakavula, "some of the defeated members of parliament addressed the question of having another coup" and Kubuabola argued that "people must be prepared to shed blood and die to get rid of the Chaudhry Government."

${ }_{152}$ Robertson and Sutherland 6. The VLV was strongly influenced by Methodist fundamentalists and sought the declaration of Fiji as a Christian country and the reinstatement of the Sunday Observance Decree. The grand Fijian alliance never really materialised due to the Christian demands of the VLV. 153 Interview with Mahendra Chaudhry (Suva, Fiji: 9 December, 2002). Chaudhry denied this charge and argued that he was simply fulfilling his duties as prime minister. Labour focused its legislative agenda on social issues such as the minimum wage, social safety net, and rural infrastructure.

154 For example, Chaudhry denied a work visa to the Editor in Chief of the Fiji Times (Fiji's largest newspaper) and reacted bitterly to critical stories by threatening to develop a licensing scheme for the media. Chaudhry also appointed an inexperienced politician as his information minister.

${ }_{155}$ Mahogany (unlike the pine plantations) is concentrated in the central and eastern provinces of Tailevu, Namosi, and Naitasiri.

${ }_{156}$ Robertson and Sutherland 9 and Interview with Samisoni Speight Tikoinasau (Suva, Fiji: December 6, 2002). Moreover, George Speight as the Chairman of the Fiji Hardwood Corporation (FHCL) was alleged to have chosen a particular tender in order to receive kickbacks from the same company and was dismissed 
Land was also a very divisive issue for the Chaudhry government. In November of 1976 the Agricultural Landlords and Tenants Act (ALTA) was enacted with a minimum lease period of thirty years with possible extensions of twenty years. Some Fijian nationalists were vocally opposed to the ALTA but relative peace over land issues was maintained until the leases began to expire in $1998 .^{157}$ When Mahendra Chaudhry became prime minister in 1999 he began the process of land reforms. ${ }^{158}$ Ultimately the Fijian nationalists seized on the land issue and portrayed the Chaudhry government as acting contrary to Fijian interests. Moreover, the NLTB, fearful of losing its monopoly, began to actively oppose the government in rural areas. Chaudhry simply did not have the grassroots infrastructure that the nationalists possessed (such as the Fijian administration and traditional system).

Opposition to Mahendra Chaudhry (as manifested in nationalist rallies) was growing rapidly. ${ }^{159}$ The Nationalist Vanua Tako Lovo Party (NVTLP), a previously insignificant political force, announced a rally would be held on the 19 th of May. In the meanwhile elements of the First Meridian Squadron plotted to overthrow the

by Chaudhry. This was a charge which he later denounced to his brother (MP Sam Speight) as "propaganda."

${ }_{157}$ The indigenous Fijian land-owners wanted leases to be based on market value (rather than unimproved value) and also sought a reduction in the lease period. They felt that indigenous Fijians' development was being held back by the government's lease policy.

158 Robertson and Sutherland 12. Chaudhry argued that his intention was to return some crown land to the indigenous Fijians. It must be remembered that the 1997 Constitution guarantees that changes to the Fijian Affairs Act, Fijian Development Fund Act, Native Lands Act, Native Land Trust Act, Rotuma Act, Banaban Lands Act, and Banaban Settlement Act can only be made with the approval of nine of the fourteen Fijian senators. Nevertheless these reforms were met with great suspicion by many Fijians who feared the loss of their land. Mara had warned Chaudhry of the divisiveness of this issue and counselled him to wait for at least two years to gain the trust of Fijians before addressing the land file. Chaudhry ignored this advice and sought to extend the length of the leases and establish a Land Use Commission. 159 Robertson and Sutherland 10. Apasai Tora held a rally in Lautoka on the 20th of April and only three hundred people attended. However, a rally in Suva eight days later attracted eight thousand people. 
government. ${ }^{160}$ During the protest on the morning of the 19 th George Speight and his conspirators raced into the parliamentary compound in two vehicles and quickly gained control of the lightly protected parliament. ${ }^{161}$

The coup plotters sought to gain the support of the military in the absence of their leader (Commodore Josaia Voreqe Bainimarama was at a UN conference in Oslo) and were even given a chance to present their case but Colonel Viliame Seruvakula (the commander of the Third Fiji Infantry Regiment) ordered his soldiers not to take part. ${ }^{162}$ Other prominent backers of the coup also chose to either withdraw their support or remain in the shadows. ${ }^{163}$

Following the coup, there was a period of institutional inertia where neither the government, nor the chiefs, nor the rebels made any significant moves and the rule of law rapidly deteriorated. ${ }^{164}$ Fierce intra-ethnic disputes over what form the government should take and how the crisis should be resolved caused this inertia. The weakness of government institutions such as the police, military, and executive also contributed to this 'leadership lag' and created a vacuum that was filled by the rebels. The willingness of the Fijian leadership to legitimate the overthrow of the elected government demonstrates

\footnotetext{
160 Robertson and Sutherland 12. They spent Good Friday (21 April) with him and during the following two weeks probably trained at Rabuka's eight hundred hectare Valavala Estate (near Savusavu on Vanua Levu). Only six soldiers were involved at first but this number increased to nine on the morning of the coup. At the last minute Captain Shane Stevens (a late recruit to the cause) deserted the coup.

${ }_{161}$ Once inside they handcuffed most coalition MP's and ministers and segregated them on the basis of ethnicity (in the hopes that this would make it easier to gain the support of the Fijians).

162 Robertson and Sutherland 15. In spite of this rejection, there is evidence that the rebels were allowed to smuggle some arms out at this point.

${ }_{163}$ Robertson and Sutherland 16. Poseci Bune (the leader of the VLV) later gave this account: "We had to wait about forty minutes as he [George Speight] was answering calls, and at the same time making calls, telling us that we would be surprised that he is not the leader, as the real leader would arrive for us to see him. But then he got another call. He turned to us and said, "I think he is going to be late. Well, I'll have to take over from here." The press has since alleged that the conspirator was Savua and that he pulled out when he learned that the military hadn't supported the coup.
} 
that they placed the value of indigenous paramountcy above democracy.

The rebels failed to receive the elite support that they needed to institutionalise

their revolution. They attempted to hamess grassroots support, inviting 'ordinary' Fijians to occupy the grounds of parliament. This ploy was also designed to use these Fijians as human shields in order to deter military and police forces from attempting to free the hostages. ${ }^{165}$ It is questionable whether the coup was really a grassroots movement or whether the coup plotters were merely using Fijians to achieve their political goals.

The strength of state institutions and the rule of law continued to crumble with the coup stalemate. ${ }^{166}$ Bainimarama greatly resented Speight and rightly saw that Speight was capitalising on the weakness of the Fijian government to press increasing demands. Consequently, George Speight, his bodyguard, lawyer Tevita Bukarac and journalist Jo Nata were arrested near Kalabu and imprisoned on Nukulau. ${ }^{167}$ At six o' clock the next morning the military launched a surprise attack on the rebel camp and arrested 369 rebels

164 Robertson and Sutherland 17. On the $23 \mathrm{~d}$ of May an "orgy of violence and looting" had erupted in the downtown Suva. This resulted in thirty million dollars in damages and the declaration of a state of emergency by Ratu Mara

165 Graeme Dobell, "The Strange Saga of Speight's Siege in Suva," in Brij Lal and Michael Pretes (eds.), Coup, (Canberra, Australia: Pandanus Books, 2001) 135 and Robertson and Sutherland 19. Speight also used the media to his full advantage encouraging them to approach even after President Ratu Mara had ordered them away from the radius of the complex. Even villagers at roadblocks began to demand to speak to the $\mathrm{BBC}$.

166 As Fiji descended into mob rule Indians in isolated communities were harassed and driven from their homes. Moreover, on the 26th of May, 18 members of an army engineering unit led by Major Joseva Savaa (the younger brother of the police commissioner Isikia Savua) joined the rebels in parliament. Later that week, three soldiers, a rebel, and a joumalist were wounded in a confrontation at the parliamentary perimeter. On June $27^{\text {th }}$ eighty soldiers under the command of Lt. Rupeni Vosayalo (Ligairi's grandson) assisted by five hundred supporters seized Sukanaivalu Barracks in Labasa and the amoury at Vaturekuka. Hours later, wo hundred rebels and soldiers clashed outside parliament with five rebels being wounded. At the Monasavu dam (in the central highlands of Viti Levu) a young medical assistant presented drugged Kava to soldiers and rebel sympathisers took over the power station. In July rebels seized Korovou (Tailevu) and held thirty policemen prisoner. Also, in Vanua Levu the Savusavu and Seagaqa police stations were captured. In Ovalau, Lovoni villagers attacked Levuka's police station, occupied PAFCO (a tuna cannery), and bumed down the local Masonic lodge. All over Fiji police posts were being seized and landowners seized the Turtle Island Resort and Laucala Island Resort (both in the Yasawa Islands) as well as, Fiji Water's plant in Rakiraki. Moreover, the inmates of Naboro Prison (Suva) rioted, took twenty-six wardens hostage, and staged a mass breakout. 
(including twelve from the FMS). ${ }^{168}$ The military had regained control of the country by

the end of July. Eventually more rebels were arrested and fifteen people (including

Speight and Ligaini) were charged with treason or related charges. ${ }^{169}$ Several First

Meridian Squadron soldiers were detained temporarily and the unit was disbanded. ${ }^{170}$

There were many attempts at conflict resolution during the months after the coup.

Fiji went through several prime ministers and the military and the chiefs both played

primary roles in the restructuring of Fiji that occurred in this period. The chiefs sought to

review the relatively progressive 1997 constitution. This was somewhat self-serving as

any changes to the constitution would likely strengthen the power of the military

traditional complex (see chapter V). The military itself deposed Ratu Mara and seized

control of the country (ostensibly to restore security). ${ }^{171}$ They took a soft line with the

rebels publicly stating that they agreed with the rebel cause but not its methods. ${ }^{172}$ When

negotiations with the rebels broke down on the 27 th of June the military appointed an

interim government headed by Laiseni Qarase. The chiefs wanted the power to be the

body responsible for choosing the president. On the 9th of July the Muanikau Accord

\footnotetext{
${ }^{157}$ Nukulau is a small island in Laucala Bay off the shore of Suva. Ironically, it was formerly used to quarantine Indian girmits.

${ }^{168}$ In the attack one rebel was killed and thirty-three were wounded. An officer that I spoke with who was present at the raid claimed that the FMF had used "more than the normal force." The rebel response was limited, Ratu Mara's cane farm (near Seaqaqa) was razed and Labasa police station was seized.

169 The High Court declared the Muanikau amnesty for the rebels invalid. Police Commissioner Savua was forced to step aside while the chief justice began his investigation.

${ }^{170}$ Misplaced attempts at "reconciliation" saw many of those involved in the coup being let of without any punishment whatsoever. Several of the rebel conspirators imprisoned on Nukulau were freed and, on the recommendation of the Chief Justice, Savua was reinstated as the Police Commissioner (without many allegations of his involvement in the coup being fully investigated).

171 Interview with member of Lau Provincial government (Lakeba, Fiji: 14 October 2002). There was enormous pressure on Ratu Mara to leave (from both the rebels and Fiji Military Forces). On May 28 his guards left their posts and the following night the military evacuated Mara on a naval vessel. FMF Commander Bainimarama visited Mara and asked him to step aside for twenty-one days so that martial law could be declared. Mara agreed but said that he was never returning to the presidency and was evacuated to his home on Lakeba in the Lau Islands. Many Lau Islanders viewed this as a coup against Ratu Mara perpetrated by Kubuna confederacy, arguing "it was terrible what they did to him."
} 
was signed whereby the rebels lay down their arms and released the hostages. ${ }^{173}$ The rebels surrendered and released the hostages but continued to exert political power.

On the 2nd of November (three days after the detained FMS soldiers were released) forty soldiers led by Shane Stevens unsuccessfully attempted to capture Bainimarama, take hostages, and seize FMF headquarters. ${ }^{174}$ In the ferocious firefight that ensued eight soldiers died, twenty were injured, and six civilians were also injured. Five rebels were allegedly beaten to death after they had surrendered. ${ }^{175}$ Complicating the political implications of the mutiny was the fact that Rabuka was present at the mutiny in full uniform and left with a rebel soldier in his car. ${ }^{176}$ Rabuka has claimed that he didn't know Captain Stevens and that he came to the barracks to act as a mediator but according to army officer Taliai Rasolo, Rabuka's car had been seen several times in the days leading up to the mutiny outside of Stevens' house. ${ }^{177}$

In two senses the coup was revolutionary: both as a Fijian revolution against the prospect of "Indian rule" and as a declaration by indigenous commoners of the increasing irrelevancy of chiefly power. The coup undermined the chiefs because commoners not only took political actions that were contrary to the wishes of the chiefs but also sought leadership positions that may have traditionally been reserved for the chiefly elite. Under

\footnotetext{
${ }^{172}$ Some western chiefs were unhappy that the military was co-operating with the rebels and began to speak of forming a separate government.

${ }^{173}$ Robertson and Sutherland 33. The rebel's cache of weapons included Uzis, handguns, several rocket propelled grenade launchers, Claymore mines, and ammunition.

${ }_{74}$ They executed three loyalist soldiers in their sleep, seized weapons and took control of Bainimarama's office, the armoury, and an operations centre. However, the mutineers failed to capture Bainimarama and executed their operation just as elements of the $3 \mathrm{~d}$ Fiji Infantry Regiment were returning from field exercises in the interior.

${ }_{175}$ In September 2002 I spoke with a Fijian woman who lived in the same settlement as several of the rebel soldiers. She recounted to me the day when the body of one of these rebel soldiers was brought back to the village and said that the soldier had been beaten so badly that his own family could not recognise him. It was also alleged to me by a former government official that at least one of the rebel soldiers killed by the army had been kidnapped from the Suva City Market and brought to the scene of the battle to be executed. 176 Robertson and Sutherland 41.
} 
Bainimarama there was also an attempt to de-politicise the military and separate it from its past role as a defender of traditionalism. However, the military-traditional-complex was not prepared to so easily ease its grip on power and there was a kind of counterrevolution following the coup. Increasing chiefly power was deemed a way to satisfy the demands of indigenous Fijians to "indigenise" the political system. The Great Council of chiefs was made more autonomous and powerful. ${ }^{178}$ The coup also had the effect of further fragmenting and polarising party politics in Fiji. ${ }^{179}$

Commentators have attributed the coup variously to such things as ethnic antagonism between Fijians and Indians or intra-ethnic conflict amongst the Fijians ${ }^{180}$ This second view holds that ethnicity was largely irrelevant and that the coup was "fundamentally an attempt to restructure the indigenous Fijian social and political structure." Ratuva argues that "there was a very complex interrelationship between inter and intra-ethnic tension" in Fiji. ${ }^{182}$ For example, although the coup was motivated at least partly by a desire for Fijian paramountcy, the coup leaders also resented the regional (Lauan/Tovata) dominance that Ratu Mara represented. The 2000 coup in Fiji was a result of the actions of George Speight and his co-conspirators but was rooted in the politicisation of identity. Beyond ethnic considerations the 2000 coup was also driven

177 Taliai Rasolo often visited his relative who lived in the same village as Stevens.

178 It was granted a twenty million dollar budget and placed under presidential rather than parliamentary oversight. This power was especially significant considering that the President himself is selected by the Great Council of Chiefs. The BLV also constructed its own administrative complex near parliament. 179 SVT supporters from Macuata and Cakaudrove provinces split from the party and formed the Conservative Alliance Matanitu Vanua (CAMV). The chiefs also abandoned the weakening SVT as their official party. Furthermore, Poseci Bune left the VLV and joined PANU. PANU itself split with Apisai Tora and Momedonu (who left the FLP) forming the rival Bai Kei Viti (BKV) party. Deputy Prime Minister Tupeni Baba also left the FLP and formed the New Labour Party (NLP).

${ }^{180}$ Steven Ratuva, "Conflicting Perspectives and Potential for Accommodation in a Plural Post-Coup Society: Rebuilding a Fractured Fiji, in Coup. Brij Lal and Michael Pretes (eds.) (Canberra: Pandanus Press, 2001) 41.

181 Ratuva, "Conflicting..." 42.

182 Ratuva, "Conflicting..." 42. 
by non-ethnic rivalries amongst the Fijian elite. Elements of this elite (predominately members of the Kubuna Confederacy) seized the Fijian State and sought to remake it in their image. They failed and the military-traditional complex was resurgent.

Figure 2.2: The Rise of ethno-mationalism in Fiji and New Callodonia

\begin{tabular}{|l|l|l|l|l|}
\hline & $\begin{array}{l}\text { Distribution of } \\
\text { Political Power }\end{array}$ & $\begin{array}{l}\text { Economic } \\
\text { Inequality and } \\
\text { Poverty }\end{array}$ & Land Rights & Demographics \\
\hline $\begin{array}{l}\text { New Caledonia: } \\
\text { Pa04 }\end{array}$ & $\begin{array}{l}\text { Kanaks utilise } \\
\text { extra-political } \\
\text { means to achieve } \\
\text { their political ends }\end{array}$ & $\begin{array}{l}\text { The Kanak } \\
\text { insurrection (Les } \\
\text { Evenements) } \\
\text { results in increased } \\
\text { efforts to achieve } \\
\text { economic equality }\end{array}$ & $\begin{array}{l}\text { Land redistribution } \\
\text { to Kanaks } \\
\text { continues }\end{array}$ & $\begin{array}{l}\text { Kanak pressure } \\
\text { results in new } \\
\text { limits on } \\
\text { immigration to } \\
\text { New Caledonia }\end{array}$ \\
\hline $\begin{array}{l}\text { Post-Colonial } \\
\text { Fiji }\end{array}$ & $\begin{array}{l}\text { Fijian forces } \\
\text { intervene to restore } \\
\text { Fijian control three } \\
\text { times after Indians } \\
\text { gain power }\end{array}$ & $\begin{array}{l}\text { Fijian resentment } \\
\text { of perceived Indian } \\
\text { affluence grows } \\
\text { and affirmative } \\
\text { action programs } \\
\text { are strengthened to } \\
\text { further benefit } \\
\text { Fijians }\end{array}$ & $\begin{array}{l}\text { Fijians retain } \\
\text { control over land } \\
\text { and further } \\
\text { increase the } \\
\text { proportion of land } \\
\text { that they own }\end{array}$ & $\begin{array}{l}\text { Major Indian } \\
\text { emigration occurs } \\
\text { after 1987 and } \\
\text { 2000 coups and } \\
\text { Fijians obtain } \\
\text { majority }\end{array}$ \\
\hline
\end{tabular}

\subsection{Conclusion}

Throughout the histories of Fiji and New Caledonia attempts have been made to reconfigure the state around the identity of a particular group (the nation-building trap). The colonial government in Fiji preserved Fijian power. In latter years the Fijians sought to build a nation-state as many of their neighbours were doing but failed to account for Indian demands for full membership in the political community. Fijian nationalism is primarily assertive in that it is not a product of marginalisation but is derived from a sense of indigenousness and of indigenous rights over the vanua. In this conception, Indo-Fijians are viewed as an obstacle to the creation of a Fijian nation-state - they 
represent a 'fly in the soup of nation-building.' The nationalists have reacted to every Fijian "loss of control" by seizing state power through extra-political means.

In New Caledonia, the French sought to completely deny and even eliminate Kanak identity. This marginalisation was transformed into Kanak resistance and political consciousness. As the much-respected indépendendiste leader Jean-Marie Tjibaou has explained, "[La notion du peuple kanak] est née de la lutte contre la colonisation, née a l'adversite (the notion of a Kanak people is born in the struggle against colonialism, born in adversity)."183

Therefore, we can see that Fijian and Kanak nationalism have emerged as a result of differing conditions. Kanak nationalism is rooted in marginalisation while Fijian nationalism is based on positive entitlements and a desire (on the part of indigenous Fijians) to retain control over the state. It is in this sense, that Fijian nationalism does not conform to Crawford and Lipschutz's arguments that the politicisation of ethnicity is a result of marginalisation and hardship.

183 Tjibaou 121, translation mine. 


\section{Contemporary Ethnic Politics and Politicisation in New Caledonia}

\section{Introduction}

In both Fiji and New Caledonia politics are primarily ethnic. Globally, ethnicity also has great saliency and ethnic politics predominate in many states. Perhaps this is because although there is a degree of fluidity to ethnicity, ethnic identity is generally not as malleable as other forms of identity such as religion and regionalism. To some extent ethnic ties can be ascriptive as ethnic difference can coincide with racial difference. This sense of difference (whether it is internally constructed or externally imposed) often makes ethnicity an easy target for the political appeals of entrepreneurs.

As argued in the introduction, marginalisation can contribute to an ethnic group's politicisation (in this case defensive politicisation). Moreover, when one ethnic group becomes politicised this is more than likely to impel the politicisation of other groups. With this type of politicisation the very survival of a particular ethnic group can be perceived to be at threat and political mobilisation is deemed to be essential. Similarly, Crawford and Lipschutz argue that the politicisation of cultural identities (such as ethnicity) is a product of the institutionalisation of difference and marginalisation. However, ethnicity has spawned ethnic nationalist movements that seek not only survival but also positive entitlements (such as indigenous rights). This assertive politicisation of ethnicity may occur, despite a lack of discrimination or hardship, where ethnic identity becomes the source of national imagining for a particular group.

Previous chapters have laid out the theoretical arguments of this thesis and examined the politicisation of identity over time. This chapter will utilise the case of the 
Kanaks of New Caledonia to examine how certain factors (such as economic inequality and poverty, the distribution of political power, social segregation, historical memory, relative demographic strength, and land rights) facilitate and sustain both types of politicisation (assertive and defensive). In addition to investigating contemporary ethnic politics and politicisation this chapter will also briefly examine the political aspirations of each major ethnic group in New Caledonia in order to gain a deeper understanding of how the dynamics of ethnic relations drive the politicisation of a particular group. The politicisation of ethnicity can be grounded in discrimination and adversity (defensive) or positive entitlements (assertive). The politicisation of the Kanaks is largely a response to their marginalisation within New Caledonia but also contains elements of assertive politicisation anchored in Kanak claims to indigenous paramountcy. Nevertheless, consistent with Crawford and Lipschutz's "cultural conflict" thesis, the primary motive for Kanak politicisation is marginalisation.

\subsection{Ethnic Identity in New Caledonia}

\section{a.) Introduction}

Ethnicity is a very significant factor in the political life of New Caledonia. Support for the primary political question, independence, is almost entirely ethnically determined. New Caledonia is also a truly a multi-ethnic state (more so than Fiji). In addition to the various Kanak and European groups there is a large Wallisian minority, as well as Tahitian, Ni-Vanuatu, Vietnamese, Chinese, and Arab minorities. Much of this 
ethnic diversity is found in urban areas, namely Nouméa. In fact, about $90 \%$ of those born outside New Caledonia call greater Nouméa home. ${ }^{184}$

Ethnicity in New Caledonia has significant spatial characteristics as Europeans are concentrated heavily in the Southern Province (Nouméa, Southern Grande Terre, and a few West Coast towns) and Kanaks are found in concentration everywhere else. Nearly $90 \%$ of the ten thousand French who migrated to Nouméa between 1971 and 1976 lived in Nouméa. ${ }^{185}$ This has led to the "Europeanisation" of the city. Walking the streets of Nouméa you could be forgiven for feeling that you are in a city on the French Riviera. The area outside Nouméa is referred to as La Brousse (the Bush) while Kanaks sometimes refer to Nouméa as La Ville Blanche (the white city). According to one Kanak woman in Nouméa: "They exterminated us here...the Kanaks don't exist in Nouméa. They fled to the bush."186 This development/ethnic dichotomy between the wealthy urban areas (Nouméa) and the poor Brousse reinforces the economic and political marginalisation of the Kanaks.

There is a strong ethnic consciousness within New Caledonia and the party system is not only ideologically aligned (between pro and anti-independence forces) but also ethnically aligned (with most Kanaks supporting one coalition and most Europeans and others supporting another). This section will examine the nature and political viewpoints of the various ethnic groups in New Caledonia so as to provide a foundation for subsequent further discussions of ethnic politics and the politicisation of the Kanaks.

\section{b.) Europeans}

184 Connell 219.

185 Connell 219. 
In the bipolar ethnic politics of New Caledonia, the Europeans are highly politicised. Europeans generally support the RPCR coalition (Rassemblement pour la Calédonie dans la République) and are opposed to the notion of independence. Within the general category of "European" there are several sub-categories. The two primary sub-categories of Europeans are Les Caldoches and Les Métros. The Caldoches are the descendants of the original European settlers while the Métros are French who have taken term contracts in New Caledonia with the government. The Caldoches have developed a unique cultural identity, which can be suspicious at times of the metropolitan government and is very much tied to New Caledonia. They have complicated feelings towards France; they are loyal but assert their unique identity and express their feelings of alienation from French bureaucrats who do not understand the needs of New Caledonia. ${ }^{187}$ They are often said to be bound together by a collective myth of the hardiness of their pioneer ancestors in their struggles against a hostile natural world. ${ }^{188}$ Another of the sub-groups within the "European" category is the "Pieds Noir." The Pieds Noir ("black feet") are former French settlers from Algeria and number around three thousand. They have a reputation for militancy and ultra-conservatism.

There are also class dimensions within the European group. Several of the original Caldoches mining and ranching families have maintained their economic and political dominance of New Caledonia over time. ${ }^{189}$ This has resulted in class divisions between these powerful families and the poor, rural Caldoches. Guiart called these rural

\footnotetext{
186 Interview with Kanak woman (Nouméa, New Caledonia: 19 July 2003).

87 Maclellan 149.

188 Many of the Caldoche are rural people involved in such activities as cattle ranching, horseback riding, and hunting. Cycling is also a big part of the Caldoche identity and the annual Tour Calćlonie was blockaded for years by Kanak nationalists. This was a way for the Kanaks to re-assert their identity, by denying the Caldoche an aspect of theirs.

${ }^{189}$ This will be discussed further in Chapter $V$.
} 
Caldoches "the most insular, without secondary education, the least capable of adaptation if forced into exile, the most violent in language and the Europeans who have the most to lose."190 This is a pretty negative assessment of rural Caldoches but there is some truth to it. The rural Caldoches are among those with the most to lose if Kanak socialist independence becomes a reality. Many rural Caldoches are conservative in their political values and are gun-owners. There is a kind of siege mentality among these Caldoches that is not unlike that of European minority settlers in other areas such as Boers of South Africa, the Pieds Noirs of Algeria, or the "Rhodies" of Zimbabwe. The threat of losing their land may have made the Caldoches more conservative. ${ }^{191}$ As one Caldoches Front Nationale supporter said:

My house, my fields, my shop, my work, its my life. No one will try to steal it from me. We have always lived in harmony with the Melanesians. My grandfather came to New Caledonia to seek gold in the mountains... we are Caldoches. We are the people of this land. ${ }^{192}$ [italics mine]

It is these more conservative Caldoches forces that resist the evolution of $\mathrm{New}$ Caledonia's national identity to reflect the Kanaks. Nevertheless, there has been an increasing recognition in recent years that in order for New Caledonia to prosper, there has to be some accession to Kanak demands.

There is sentiment among many Caldoches that the Métros are not loyal to New Caledonia and that they are simply an encumbrance who take employment from New Caledonians. The Caldoches sometimes refer to Métros as "Zoreilles," or "big ears" because of they supposedly are always listening and reporting what they hear to France.

\footnotetext{
Connell 141.

191 Connell 141.

192 Connell 142.
} 
In return many Métros view the Caldoches as being rough and unsophisticated. As one Métro told me near Hienghène,

The Caldoches have a connection with the land and they want to keep it. They are a bit hard-headed... a bit vulgar. They have a sense of superiority in relation to the Métros... ${ }^{193}$

European identity in New Caledonia is both complex and highly politicised. Europeans have been in New Caledonia for generations and although they represent a distinct community, they still have strong ties to metropolitan France. These ties may stem partially from a fear over the nature of the independence movement, that is grounded in an ethnic (Kanak) nationalism which may be perceived to threaten Caldoches' identity. ${ }^{194}$ In this sense, the politicisation of the Caldoches is defensive in nature (although it is not grounded in discrimination and there are certainly assertive aspects to the French imperialism that protects the Caldoches). The Europeans (and their ethnic allies) have constituted a majority in New Caledonia for at least two decades and therefore they have been more likely to support democratic mechanisms for conflict resolution such as referendums. The Caldoches of New Caledonia are in a similar position to the Indians of Fiji in that they lack the ability to assert "indigenous" claims as an anchor for their status in New Caledonia, yet their historical roots in the country are multi-generational. They are both the force that denies the Kanak national dream and "victims of history."

\section{c.) Kamaks (Melanesiams)}

193 Conversation with a Metro near Hienghène, July 2002.

194 This is changing as the FLNKS and other groups realise that the support of Europeans is essential for the achievement of independence. 
The Kanaks are the indigenous Melanesian peoples of New Caledonia. With the Europeans the Kanaks represent one of the two competing groups in the ethnic bipolarism of New Caledonia. Like the Caldoches, Kanak identity is tied to the land. However the Kanaks are native to New Caledonia and have occupied that territory for thousands of years. This notion of "indigenousness" suffuses Kanak political consciousness.

It is important to recognise the diversity of Kanak identity (there are still twentyeight Kanak languages spoken today). Kanak identity exists on several levels with more localised cultural identities (the remnants of pre-colonial Kanak nations), and a national political identity which has arisen in response to external pressures. The term "Kanak" (Canaque in French) was a pejorative term used to distinguish indigenous inhabitants from civilised people. But like the word "nigger" in the United States, rising political consciousness has led the Kanaks to assert their ownership of the word. ${ }^{195}$ Most Kanaks support the FLNKS (Front de Libération Nationale Kanak et Socialiste) coalition of parties which favour independence.

The politicisation of Kanaks has both assertive and defensive aspects. The Kanaks have endured the harsh assimilationist repression of French colonialism (Kanak cultural survival was deemed to be at stake) and Kanak political mobilisation has largely been a reaction to these pressures. Thus Kanak nationalism is primarily defensive in nature.

The other aspect of Kanak nationalism is an avowal that Kanaks have a special claim to paramountcy over the land by virtue of their status as the indigenous inhabitants.

\footnotetext{
195 As one conservative Caldoche contended, "Melanesians have become Kanaks, with a 'K' like Karl." This also reflects the socialist ideology embraced by the nationalist movement. See Connell xiv.
} 
This second assertive form of politicised Kanak identity is somewhat more exclusionary. As Kanaks have become a demographic minority they utilised their indigenous status as the basis for their demands for political control rather than the principal of democratic majority. Moreover, the failure of the French state to attempt to accommodate Kanak nationalist demands within the political system has led some nationalists to seek extrapolitical means to achieve their national goals. Like the Europeans, Kanak nationalists are becoming increasingly accepting of the multicultural fact of New Caledonia and that this must be reflected and incorporated into any national identity. They have themselves recognised that the Caldoches are "victims of history."

\section{d.) Wallisians and Tahitians (Polynesians)}

The presence of a large Polynesian minority in New Caledonia further complicates ethnic politics. Although there are Wallisian-based political parties, the Wallisian community and parties tend to ally themselves with the Europeans and be opposed to independence. This is not surprising considering that they came to New Caledonia to work in a part of France and the prospect of Kanak independence might threaten their place in the country. There is not really a Wallisian nationalist movement and Wallisian political demands are subsumed under the bipolar politics of New Caledonia. The Wallisian ethnic alliance with the Europeans is a form of defensive politicisation, as the Wallisians perceive Kanak nationalist aspirations as being a threat to their position in the territory. 
The Wallisian population tends to be fairly young and economically depressed. ${ }^{196}$ This puts them in direct competition with Kanaks in the job market. The Kanaks regard the Wallisians as being "culturally inferior, clamnish, and quarrelsome." 197 Most Wallisians are opposed to independence and therefore many Kanaks view the Wallisians as foreigners (like the Europeans) who are interfering with Kanak national aspirations. ${ }^{198}$ An important recent political development in the Wallisian community is the formation of a Wallisian pro-independence political party in the FLNKS named the Rallée Democratique Océanienne (RDO). The party has yet to gamer much support but it does show that the Wallisian community itself has divided loyalties. In an independent New Caledonia, the Wallisian community may begin to assert more political and economic demands as ethnic bipolarisation gradually declines.

\section{e.) Other Minorities}

The multicultural character of New Caledonia has been forged by waves of economic migrants. ${ }^{199}$ These groups are less politicised than the Kanaks, Europeans, and Wallisians and generally ally themselves with the Europeans. The prevailing Kanak

\footnotetext{
${ }^{196}$ In $198346 \%$ of Wallisians were less than fifteen years old. Also, the majority of New Caledonia's estimated six thousand squatters are Wallisian. Many Wallisians live in poverty in New Caledonia but are unable to return to Wallis. See Connell 221 and Bernut-Deplanque 19.

397 Connell 223.

198 In August of 2002 I witnessed a violent confrontation on the streets of Nouméa between a Wallisian and a Kanak gang, complete with racial slurs. There are some indications that racial tensions between Kanaks and Wallisians in New Caledonia are actually increasing. In 2002, there violent land disputes between Wallisians and Kanaks in Saint Louis. After the Saint Louis clashes there have been increasing attempts for the two communities to reach out to each other. The Kanaks are also aware that they cannot win independence without the support of at least some of the other Pacific Islanders residing in New Caledonia.

199 As stated previously these included Chinese, Japanese, Arabs, Vietnamese, Ni-Vanuatu, and Javanese. After the Second World War the number of Asian migrants fell and came to consist almost entirely of Vietnamese and Javanese.
} 
perspective towards these immigrant groups is not favourable. ${ }^{200}$ Their ethnic alliance with the Europeans (like that of most Wallisians) arises from their reluctance to embrace the goals of the Kanak nationalist movement. By definition the independence movement in New Caledonia has been centred on Kanak nationalism but Kanak nationalists are increasingly striving to make their national dream more inclusive by reaching out to other groups.

\subsection{Ethnic Competition and the Politicisation of Ethnicity in New Caledonia}

\section{a.) Introduction}

The politicisation of ethnicity is rooted not only in marginalisation and the competition between ethnic groups but also in positive entitlements. Both of these scenarios are driven by a perceived lack of control, a perception which can arise from several factors such as relative political power, economic inequality and poverty, relative demographic strength, social segregation, historical memory and land rights. This section will outline how each of these factors has facilitated the creation of the conditions that allowed the politicisation of ethnicity in New Caledonia.

\section{b.) Social Segregation}

The economic division between the races is also reflected in the social reaim. In both Fiji and New Caledonia the intense political competition and bipolarisation has

200 Connell 225. For instance, in the aftermath of the Santo Rebellion in Vanuatu (1980) there was an influx of about $1200 \mathrm{Ni}$-Vanuatu 'refugees' to New Caledonia. According to Kanak nationalist Susana Ounei, Union Caledonienne party militants reacted by arguing at their 1982 Congress: "That the refugees from Santo be repatriated to France because they constitute a danger for Kanak independence. The Kanak state is not the waste-bin of the Pacific...the new migrants (since 1972) were all traitors (that is supporters of French imperialism) from Algeria, Vanuatu, Vietnam. We get that sort of refugee! We haven't any 
created a situation in which there is a kind of informal segregation in the social sphere. In New Caledonia this segregation seems to be decreasing somewhat after the recent two accords, but there remains a strong social division between the various ethnic groups. For example, Pascal Vittoria (of the Alliance Party) observed that in Nouméa, Europeans frequent one beach and Kanaks another. ${ }^{201}$ As identity becomes more inclusive in New Caledonia in the coming years and economic inequality decreases, one might expect that old social divisions may also be challenged. A lack of social interaction between ethnic groups (or other identity groups) may contribute to perceptions of difference.

\section{c.) The Distribution of Political Power}

Kanaks have largely been excluded from the political life of New Caledonia throughout its history. This is a primary grievance of the Kanak nationalist movement and a motive for the continuing politicisation of the Kanaks. In both Fiji and New Caledonia the central axes of political competition is centred on two dominant ethnic groups. In this sense, both cases can be characterised as being ethnically bipolar. ${ }^{202}$ Almost all political parties are essentially ethnically-based and there is a strong ethnic basis for voting behaviour as well. As political competition becomes more extreme a survival discourse develops whereby entrepreneurs in each group portray the very survival of their group as being threatened by the increasing power of the other group. Increasing levels of polarisation driven by competition between ethnic groups leads to an increasing politicisation of ethnicity.

refugees from oppression in South America or South Africa - for example - the true refugees. No, we get the traitors of the world - the rubbish of the world."

201 Interview with Pascal Vittori (Nouméa, New Caledonia: 8 August 2002). 
In New Caledonia the ethnic bipolarisation of politics has become almost absolute with most pro-independence parties, under the FLNKS coalition banner, gaining the majority of Kanak support. Most anti-independence parties are now under the RPCR coalition and draw their support from Europeans and ethnic groups other than Kanaks. Politics may be more conciliatory between elections but during election campaigns ethnic appeals and bipolarisation come to the fore.

\section{d.) Distribution of Economic Resources}

In New Caledonia economic inequality and perceptions of economic inequality have played a significant role in ethnic antagonisms. There is a class dimension to ethnicity in New Caledonia. Kanaks have played a relatively minor role in the economy. Much of the profit reaped from the mineral wealth of Kanak land has never touched a Kanak hand. Furthermore, there can be no doubt that the sum of repatriated capital is greater than the sum of French investment in New Caledonia. ${ }^{203}$

Melanesians had, and continue to have, lower-paid and lower-status jobs than Europeans and other ethnic groups (with the possible exception of Wallisians). ${ }^{204}$ Even when Kanaks have been employed they have earned ten to fifty times less than the average urban European and five to twenty times less than rural Europeans residing in the

202 See R.S. Mine, Politics in Ethnically Bipolar States, (Vancouver: University of British Columbia Press, 1981).

203 Connell 52.

${ }^{204}$ Connell 157. Some statistical background is useful here. In $197365 \%$ of employed Kanaks were servants or labourers and there were only two Kanak executives out of a total of 860 executives in New Caledonia. At the end of the 1970's there were no Kanak doctors, lawyers, economists, or engineers and only seven Kanak university graduates and one secondary school teacher! Moreover, of eight hundred sixty high-level and six hundred fifty middle level positions in the formal sector of New Caledonia only two high-level and seven middle-level were occupied by Kanaks. In 1981 there was still only one Kanak doctor, one architect, and one journalist. By 1984 twelve out of five hundred four secondary school teachers and lecturers were Kanak. 
same area. ${ }^{205}$ The very low income tax in New Caledonia is another factor favouring the higher-income Europeans over the low-income Kanaks as it has lessened the scope for redistributive mechanisms. The reasons for this gross disparity are myriad and include such things as institutional discrimination, geographical distance, and a lack of training and education. ${ }^{206}$ Perceptions of economic inequality and discrimination can contribute greatly to feelings of marginalisation in an ethnic group and act as a rallying point for political mobilisation.

\section{e.) Relative Demographic Strength}

In states with a high degree of ethnic politicisation demographic dominance and stability become primary aspects of political discourse. In New Caledonia it was the policy of the French government to try to overwhelm the Kanak population and nationalist movement with a flood of immigrants. It was demographic warfare at its crudest and most effective. This has also created a situation where the Kanaks have been reduced to a plurality and face great difficulty in achieving their nationalistic goals through democratic processes. To some extent this has spurred the Kanaks into challenging the French State's monopoly of economic and political power through extrapolitical means, including violence. The Kanak nationalist movement has demanded (and achieved) stricter immigration controls to New Caledonia. This is essentially a means to guarantee that Kanaks will not become further demographically and politically marginalised in New Caledonia.

\footnotetext{
205 Connell 162.

206 Connell 157.
} 


\section{1.) Land Rights}

Land is of fundamental importance in the ethnic politics of both Fiji and New Caledonia. In situations of ethnic conflict land is more than a mere economic resource, it is a symbol of the status and survival of the group. John Connell writes of New Caledonia:

In terms of its economic value to New Caledonia agriculture is of trivial importance; its social significance, especially when Melanesian subsistence food production (excluded from GNP calculations) is considered, is great and wide-ranging, from the conservatism and recurrent dreams of Caldoches to the optimism of Melanesians recolonizing their own land. ${ }^{207}$

Furthermore, much of the land redistributed to Kanaks has been from poor grazing lands on the West Coast of Grande Terre. Land rights have also recently become an issue in relations between Kanaks and Wallisians; there have been ferocious land disputes and violent clashes between Kanaks and Wallisian settlers in the Saint Louis suburb of Nouméa. $^{208}$

\section{g.) Historical Memory}

New Caledonia provides an interesting example of the importance of historical consciousness in nationalist movements and the politicisation of ethnicity. The current marginalisation of Kanaks that fuels the nationalist movement is but a hollow shell without the perceived continum of historical grievance (which also serves as a source for both heroes and villains). For example, Chief Atai (of the 1878 revolt) is a

${ }^{207}$ Connell 142.

208 Pasifik Nius, "Kanaks Mourn First Victim of Ethnic Tension," Noumea: Oceania Flash, South Pacific Commission, 12 February 2002. The Saint Louis conflict was essentially a land dispute and resulted in several deaths before it was resolved through negotiations. 
contemporary icon of the Kanak independence movement (in Nouméa there are t-shirts sold bearing his image). Moreover, the charred remains of the car ambushed in the Tiendanite Massacre remains by the side of the Hienghène Valley road where it now sits garlanded with flowers as a nationalist monument. Also, in the village of Tiendanite the graves of the victims are marked by wooden crosses painted with the FLNKS flag. The French marginalisation of the Kanaks has sought to destroy Kanak history (and therefore identity) and in doing so has actually made it a powerful symbol. ${ }^{209}$ History also provides a group with a sense of shared experience. It is in these ways that historical memory is a factor that contributes to the continued politicisation of the Kanaks.

\subsection{Non-Ethnic Factors and Ethnic Politics}

Even in states such as New Caledonia, where much of political life revolves around ethnicity, there are other non-ethnic factors that may either reinforce the politicisation of ethnicity or even challenge ethnic pre-eminence in political competition. In New Caledonia the underdevelopment of the primarily Kanak rural areas reinforces Kanak marginalisation and politicisation. There are also elements of intra-ethnic conflict among both the Kanaks (Grande Terre Kanaks versus Loyalty Islands Kanaks) and the Europeans (Caldoches versus Métros) but the intensity of ethnic conflict reduces the effects of these intra-ethnic cleavages.

A rural-urban split exists in New Caledonia that has economic, social, and political implications. Urban Kanaks are more likely to be closely tied to the

\footnotetext{
209 At a 1987 rally elements of the right burnt thousands of books and documents on Kanak history and culture at the Noumea dump in a stunning display of the racism of negation
} 
administrative system and opposed to independence. ${ }^{210}$ Furthermore, there is a huge disparity in New Caledonia between rich Nouméa and the poor Brousse. The South Province (where Nouméa is located) has $68 \%$ of the total population and $84 \%$ of tertiary sector employees. ${ }^{211}$ Even more indicative of the rural-urban disparity in New Caledonia is the fact that no less than $38.75 \%$ of the total population lives in Nouméa alone. ${ }^{212}$

There is a great degree of urbanisation in New Caledonia as people seek better opportunities in urban centres. ${ }^{213}$

Pascale Bernut-Deplanque identifies three circles of development in New Caledonia: the first is Nouméa, the second are the weakly urbanised areas (such as Koné in the North Province and Bourail in the South), and the third are the tribal areas spread throughout the rest of New Caledonia and isolated from the principal axis of development. ${ }^{214}$ This is consistent with the core-periphery theory of development: the core (Nouméa) has developed by drawing resources from the periphery (La Brousse). ${ }^{215}$ Because Nouméa is dominated by Europeans and La Brousse by Kanks, one could extend the core-periphery argument to say that in New Caledonia Europeans are the core and

\footnotetext{
${ }^{210}$ Maclellan 156. Examples of such urban Kanak leaders include Dick Ukeiwe, Auguste Reybus Parawi, and Maurice Nenou.

211 Bernut-Deplanque 19.

212 Bernut-Deplanque 19. The majorities of counties (twenty-two of thirty-three) in New Caledonia have less than three thousand people. Outside of the Noumea (which is a special case), only two counties possess a population of ten to twenty thousand (Dumbéa and Lifou) and one of more than twenty thousand (Mont Doré).

213 Jean-Pierre Doumenge, "New Caledonia from the Human Angle," in Christine Jost (ed.), The French-Speaking Pacific, (Mount Nebo, Australia: Boombana Publications, 1998). This migration, as well as, the large number of unused and abandoned properties and buildings, has led to the development of large squatter settlements in Nouméa. The built-up space within the city limits of Nouméa has expanded from 760 hectares in 1960 to 2240 in 1993 and suburban sprawl has resulted in the formation of satellite communities such as Dumbéa and Mont Doré

214 Bernut-Deplanque 21.

215 Geography Dictionary, http//www.geoexplorer.co.uk/sections/dictionarv/c.htm, accessed on July $20,2003$.
} 
Kanaks are the periphery. ${ }^{216}$ Much of the development efforts today are focussed on correcting this imbalance. The Nouméa Accord lists the "rebalancing" of New Caledonia as one of its goals and efforts have been made in this direction. ${ }^{217}$ The rural-urban divide in New Caledonia reinforces ethnic divisions and the politicisation of ethnicity.

As noted above, there is a degree of intra-ethnic conflict among both the Kanaks (Loyalty Islanders versus Grande Terre Kanaks) and Europeans (Métros versus Caldoches). The divisions among the Europeans have already been discussed in the section on the Europeans (3.2b) so we will focus on the Kanaks here. The Loyalty Islands differ somewhat culturally from Grande Terre in that there is more of a Polynesian influence. Many Loyalty Islanders now live in Nouméa where they have gained a foothold in the administration. ${ }^{218}$ Despite this the Loyalty Islanders have maintained a sense of being distinct from the rest of the Kanaks and have been among the most strident supporters of independence. Moreover, as discussed in Chapter Two Kanak identity was very localised in the pre-colonial period. These divisions within the Kanak community have largely been subsumed under the ethnically bipolar political competition of New Caledonia but after the independence question is settled and ethnic competition becomes less of a factor many of these local identities may become politically resurgent. $^{219}$

\footnotetext{
${ }^{216}$ Kanaks are the majority in the two least developed provinces: North Province, and Loyalty Islands Province.

217 The state has constructed three technical schools and colleges in the Northem province and plans to try to build a major urban centre in the Nepoui-Kone axis (contingent on plans for the opening of new mines in the area) and another smaller one at We on Lifou Island.

218 Connell 234 . In 1982 Loyalty Islanders from Lifou occupied fully $49 \%$ of the Melanesian, Nouméabased positions in the public service and Maré and Ouvéa occupied another $26 \%$.
} 


\subsection{Coricusion}

The Kanak nationalist movement in contemporary New Caledonia is grounded largely in Kanak perceptions of marginalisation. This marginalisation has political, economic, and demographic dimensions. The historical marginalisation of Kanaks has also contributed to their sense of alienation and ultimately their politicisation. Politics in New Caledonia are ethnically bipolar as political competition revolves around the Kanaks and Europeans. This ethnically bipolar competition also contributes to the Kanaks' perception of threat and therefore to their continuing defensive politicisation. To borrow Crawford's terminology, the social contract in New Caledonia dictates that Kanaks have a lesser political and economic role than Europeans. This social contract is maintained through the coercive force of the French imperial state. The defensive politicisation of Kanak ethnicity, grounded in marginalisation, corroborates Crawford's argument that politicisation is derived from hardship and discrimination.

219 The past fifteen years have seen several attempts at the accommodation of the demands of the various ethnic groups of New Caledonia. If these exercises in accommodation are successful one would expect a 


\section{Contemporary Ethnic Politics and Politicisation in Fiji}

\section{Introduction}

There are many similarities between the ethno-political dynamic in Fiji and that of New Caledonia. In both states competition revolves around two dominant ethnic groups. This bipolar competition has the effect not only of suppressing the interests of other ethnic groups but also of suppressing intra-ethnic conflict. As I have argued throughout this thesis, the politicisation of identity is caused by a perceived lack of control. This perceived lack of control could arise from such factors as political and economic inequality, the distribution of land, demographics, and historical memory. Moreover, this perceived lack of control can be defensive (rooted in discrimination and hardship) or assertive (grounded in notions of positive entitlement and national imagining). This chapter will utilise these factors as an analytical framework to examine the continuing politicisation of ethnicity (particularly Fijian ethnicity) in Fiji. Contrary to Crawford and Lipschutz's argument that the politicisation of ethnicity is grounded in discrimination and hardship, the continued politicisation of Fijians results more from Fijians' desire to shape the identity of the state.'

\subsection{Ethmic Identity in Fini}

2.)

\footnotetext{
1 Indians are viewed by Fijians as somewhat of an obstacle to realising the vision of a Fijian state.
} 
Like New Caledonia, the politicisation of the ethnic groups in Fiji has taken different forms. ${ }^{221}$ Both in terms of demography and political discourse, Fiji is an ethnically bipolar state. There are also other ethnic groups present however, which may sometimes play an important political role. ${ }^{222}$

In Fiji, race permeates every aspect of political, social, and economic life. Many seats in parliament are allocated on the basis of ethnicity (communal seats) and ethnicity is a determining factor for the state's distribution of resources (such as access to loans and university scholarships). The construction of systems of ethnic privilege (such as exists in Fiji) is argued by Crawford to be one of the primary causes of the politicisation of ethnicity. From the moment of your birth you are given an ethnic label. ${ }^{223}$ It is also illustrative of the ethnic divisions of Fiji that there is no widely accepted name for the Fijian people. ${ }^{224}$ This is indicative of the exclusionary nature of the Fijian State, which has often sought to construct identity on the basis of Fijian ethnicity rather than on shared citizenship.

\section{b.) Fijians (Indigenous Melanesians, Kai Viti)}

The Fijians are the indigenous people of Fiji, own most of the land, and are

\footnotetext{
221 The conflict in Fiji is generally described as an ethnic conflict, but given the diverse ethnic origins of the Indian population this may be somewhat of a misnomer. However, perhaps one can argue that the diverse ethnic groups have been somewhat consolidated into a new Fiji Indian ethnicity.

${ }_{222}$ Fiji Islands Bureau of Statistics, Fiii Facts and Figures, 2002 Edition. As of 1996 (the last census results tabulated) the ethnic break-down was $50.8 \%$ Fijian, $43.7 \%$ Indian, $1.5 \%$ part-European, $1.3 \%$ Rotuman, and 2.7\% "other" (including Europeans, Chinese, and others).

${ }^{223}$ For instance, on entering the country you are asked to check a box beside one of the following categories: Fijian, part-Fijian, Chinese, European, or Indian. The same happens when you go to the doctor. Even all of the student associations at the University of the South Pacific are organised on the basis not only of nationality (Tongan Students' Association, Cook Islands Student Association) but ethnicity (Indian Students' Association, Fijian Students' Association).

${ }^{224}$ As stated in the first footnote of this paper, in common usage, Fijian only refers to indigenous Fijians and not to Indians or anyone else. The 1997 Constitution introduced the term "Fiji lslanders" to represent all citizens of Fiji but the term has yet to gain wide acceptance.
} 
politically-dominant. Because of the practical importance of race (in terms of land rights, voting power, social services, import quota allocations, government employment, etc.) there has been a very open institutionalisation of ethnicity (consistent with Crawford and Lipschutz's argument that the institutionalisation of ethnicity politicises it). To be considered a Fijian you must be registered on the Vola ni Kawa Bula (VKB, or Fijian Register). ${ }^{225}$ Being a Fijian brings with it not only entitlements but traditional obligations (such as village duties and levies).

As with the Kanaks in New Caledonia, the diversity of pre-colonial indigenous identity in Fiji is still reflected in the many present-day local dialects of the Fijian language and enduring traditional rivalries. Some commentators, such as Brij Lal, have gone so far as to say "there is no one single, cohesive Fijian identity and tradition to speak of except in opposition to other groups.",226 There is some truth to this but these pre-colonial identities have been consolidated somewhat into a cohesive Fijian identity. There are local variations of this identity to be sure, but there is still a sense of Fijianness that all Fijians possess.

Like the Kanaks of New Caledonia, the politicisation of Fijians is both assertive and defensive. However, unlike the Kanaks, Fijian politicisation is primarily assertive in that Fijians have not faced significant discrimination. Fijians have been the main political protagonists and have effectively controlled the state in the post-colonial period. ${ }^{227}$ The defensive aspect of Fijian politicisation is that the Fijians have felt themselves to be economically disadvantaged vis à vis the Indians. Moreover, for much

\footnotetext{
${ }^{225}$ People are generally registered on the VKB soon after birth by their parents. If they are the offspring of two Fijian parents, then they qualify automatically but they must identify a Matagali (kinship unit). ${ }_{226}$ Brij Lal, "The Sun Set at Noon Today" in Brij Lal and Michael Pretes (eds.), Coup (Canberra, Australia: Pandanus Books, 2001) 16
} 
of the $20^{\text {th }}$ century the Fijians have been a minority in Fiji. The assertive aspect of Fijian politicisation stems from the notion of indigenous entitlement that Fijians feel over their land. The presence of the Indians (a colonial import) has denied the Fijians the "right" to have a state that is uniquely theirs. Furthermore, the primary motivation for Fijian politicisation has been this quest to indigenise the state.

\section{c.) Indians (Indo-Fijians, Kai Hindi)}

This little village is my second womb This little island will be my only tomb; That formed-deformed my father's breath This is the country of my life and death! - Vijay Mishrah ${ }^{228}$

The Indians of Fiji are highly politicised. They have somewhat of a dual identity; they are part of the great Indian global diaspora and yet their identity is also rooted in their long history in Fiji. ${ }^{229}$ In one sense, the Indians of Fiji are no longer Indians but Fiji Indians. Even though Indo-Fijians retain many aspects of Indian culture such as food, language, dress, etc. they have developed their own vemacular versions of them. ${ }^{230}$ Many Indo-Fijians have little direct contact with their country of origin. This is especially true for young Indo-Fijians who often do not even know what part of India

227 As noted in Chapter II the Fijians also enjoyed a privileged status in the colonial period.

Vijay Mishrah, "Indo-Fijian Fiction and the Girmit Ideology," in South Pacific Images, Christ Tiffin (ed.), (Australia: South Pacific Association for Commonwealth Literature and Language Studies, 1978) 64 .

${ }^{229}$ The British Empire also brought Indians to Guyana, Trinidad, and Malaysia as indentured labour.

230 One example of this is Fiji Hindi which although a form of Hindi it is much simplified and contains words from English and Indian languages other than Hindi (such as Punjabi). 
their family is from. Imrana Jalal writes, "we are not Indians. The die was cast some time ago. We are Fijians first and then we are Indo-Fijians."231

Unlike some of the other countries of the diaspora, Indians have never been fully accepted in Fiji. This has left many Indo-Fijians unsure of their place in the country. As Indian poet Sudesh Mishra wrote, "the system...has never actually allowed us to say that this particular grain of soil is yours, that you belong to it, that you can actually plant roots. So there is a kind of airiness between the earth and the feet for the Indo-Fijian.",232 The coups have reinforced this sense of not belonging for many Indo-Fijians, "the coups have forced many fourth and fifth-generation Indo-Fijians like myself to look at our roots in an effort to understand why the Indian presence is so resented in Fiji." ${ }^{, 233}$ Indians have reacted in different ways to the pressure placed on them by the coups, some repressing their Fiji identity completely, and some asserting their belonging to Fiji. ${ }^{234}$ Those who repress their Fiji identity often 'vote with their feet' by leaving Fiji for other countries. This has only decreased the Indians political power and reinforced their secondary political position in the country.

Indian-based political movements have sought equality in democratic institutions as a means of political enfranchisement and legitimacy. In this sense the politicisation of Indians has largely been defensive, seeking to secure Indians' status and rights within Fiji. Despite these efforts, the status of Fiji's Indians remains ambivalent: the most

\footnotetext{
231 Imrana Jalal "Fiji's 2001 Elections: Rebuilding a Fractured Nation" in Kim Gravelle (ed.) Good Govemance in the South Pacific, (Suva, Fiji: University of the South Pacific, 2002) 30.

232 Usha Sundar Harris "Outcasts of the Pacific" in Brij Lal and Michael Pretes (eds.) Coup. (Canberra, Australia: Pandanus Books, 2001) 57.

233 Harris 55.

234 One example of the former approach is a friend of mine who refused to be called Indo-Fijian because she said that after the 2000 coup she just considered herself Indian
} 
progressive Fijian nationalists only acknowledge that the Indians have a right to a subordinate political role within Fiji.

\section{d.) Rotumad (Kai Rotuma)}

Fiji's Rotumans are indigenous people who reside on the northern Fiji island group of Rotuma and are ethnically distinct from Fijians. ${ }^{235}$ The Rotumans are granted special status under the constitution (including the right to appoint a senator) and have traditionally been sympathetic to the Fijian nationalist movement. Not unlike the Wallisians in New Caledonia, the Rotumans consistently align themselves with another of the main political protagonists (in this case the Fijians).

\section{c.) Part-Fijians (Kai Loma)}

The Kai Loma of Fiji have a unique and somewhat ambiguous status in Fijian society. They are rarely considered wholly Fijian but this is not always the case. ${ }^{236}$ For example, George Speight (a prominent leader of the 2000 coup in Fiji) is a Kai Loma who has come to be accepted by Fijians as a nationalist. He changed his image drastically between his previous incarnation as a businessman and his new image as a

\footnotetext{
235 The Rotumans are a Polynesian people and therefore speak a different language and practise a different culture than the Fijians. The Roturnans have also shown that politically they consider themselves to be distinct from other identity groups in the Fiji Islands and immediately after the 1987 coup Ronuma declared independence. This movement was quickly quelied by a bloodless military intervention. It is also important to note that many Rotumans live and work in Suva.

${ }_{236}$ Part-Fijians can qualify for the VKB but a Mataqali must accept them. It is a tradition in Fijian culture that people may be adopted by a particular Mataqqali but will have some sort of secondary status. In the colonial era Kai Loma would sometimes suppress the Fijian aspect of their identity and in return they could be considered as Europeans and obtain employment as middle-level bureaucrats or small plantation owners. In modern times there have been Kai-Loma who have emphasised the Fijian aspects of their identity and have risen to be Fijian nationalist political leaders. Two prominent examples of this are Jim Ah Koy, the former minister of Finance and Rabuka loyalist and George Speight, the leader of the 2000 coup. Both Ah Koy and Speight's father (Sam Speight) adopted Fijian names and were registered on the VKB. Sam
} 
Fijian nationalist. One joumalist wrote, "anyone who crossed Speight's path before he shot to international fame... will recall a foul-mouthed viavialevu [upstart], trousers [not sulu] freshly pressed, mobile phone constantly in hand, and boasting of the next big deal." 237

There are some commentators who have gone so far as to attribute the 2000 coup to social-psychological reasons such as that George Speight had to prove his Fijianness by taking extreme actions. As Vijay Mishra argues, "for the Kailoma to ingratiate themselves into the Taukei there has to be excess...there has to be a return to the symbolic sulu [to exchange] urban gait [for] village swagger."238 It is interesting to note that neither the leader of the 2000 coup (George Speight) nor the leader of the November 2000 mutiny (Captain Shane Stevens) were full Fijians. ${ }^{239}$ The Kai Loma have often supported Fijian-based political movements.

\section{1.) Other Fiji Islanders: Europeans, Pacific Islanders, Chinese, etc.}

The other Fiji Islanders play a relatively minor political role. ${ }^{240}$ They have their own communal electoral category (general voters) and have tended to side with Fiji's moderately nationalistic parties such as the SDL and SVT. Chinese are currently the largest proportion of immigrants to Fiji and these new immigrants combined with the establishment of a satellite campus of Central Queensland University, serving mosty Chinese nationals in Suva, has resulted in a more prominent Chinese presence in the

Speight was registered at birth into his mother's clan under the name Savenaca Tokainavo and only started to use his father's name to get a desk job at the Vatukoula gold mine. See Nayacakalou 18 and Mishra 62.

${ }^{237}$ Roberson and Sutherland 146.

${ }^{238}$ Mishra 63.

239 Speight was half-European, half-Fijian and Stevens was half-Rotuman, half-European.

240 This political role is somewhat magnified by the 1997 Constitutioin 
capital. There also seems to be a growing resentment against this Chinese community among both Indians and Fijians with repeated allegations that the Chinese are engaged in organised crime and other illicit activities. The minor political strength of these groups corresponds to their relatively small numbers.

\subsection{Ethnic Competition and the Politicisation of Ethnicity in Contemporary Fipi}

\section{a.) Introduction}

Many of the same factors (including social segregation, the distribution of political power, land rights, relative demographic strength, and historical memory) that drive the continuing politicisation of Kanak identity in New Caledonia also impel the politicisation of Fijian identity. Moreover, like New Caledonia, Fiji is an ethnically bipolar state and the competition between Fijians and Indians supersedes all other forms of political discourse. In one sense the politicisation of Fijians is defensive because Fijians perceive Indians as being a threat to their economic well-being and political hegemony in their country. Yet Fijians have largely maintained control over their political destiny and their land and they are now in the majority. The emergence of Fijian nationalism was more a Fijian reaction to the perceived Indian threat to their hegemony over their own land (historically Fijians were the only inhabitants in the Fiji Islands) than to any real discrimination.

\section{b.) Social Segregation}

The political and economic divisions between ethnic groups in Fiji are also reflected in the social sphere where a type of informal segregation between ethnic groups often 
occurs. Supporting this argument, Williams and Saksena found that when polled with the question, "Do you mind if one of your close relatives were to marry someone not of your own race?," $20 \%$ said they would mind a lot, $20 \%$ said that they would mind a little, and only $33 \%$ said that they would not mind at all. ${ }^{241}$ Imrana Jalal emphasises the need for social integration between ethnic groups in Fiji:

We must...start by forming sincere and more meaningful friendships with indigenous Fijians...There is very little...mixing and socialising at a level that is not superficial or formal... we work with them and our children play together. But do we really? Are they truly friends? Don't most of us look down on them? Don't we call them 'jati' behind closed doors? (as they call us carawa pani!) Don't we laugh at them because they place more emphasis on customs, traditions and non-material things than on working for money or on material things, like we do? Are these not things that are actually truly admirable?... Do we learn about their culture, learn their language or their dances or understand their rituals? Do we try to understand how desperate they feel about losing to the cash economy and western development the things most precious to them...do we welcome them as sons or daughters-in-law ${ }^{242}$

This lack of social interaction surely only increases the misperceptions that ethnic conflict is rooted in. Bipolarisation seems to be increasing as a result of Fiji's repeated coups. $^{243}$

One of the major sources of this lack of social interaction is the virtually segregated education system that exists in Fiji today. Religious groups run most̂ schools in Fiji and since religious affiliation is almost synonymous with ethnicity, education is effectively segregated. There are some Fijian students who go to Indian-run schools and vice versa but they are few in number and may not receive government support. Real

\footnotetext{
241 Esther Batiri Williams and Kaushek K. Saksena, Labours Victory: Electoral Behaviour and Opinion in Fiji, (Fij: University of the South Pacific, 1999) 98. 242 Jalal 31.

243 For example, a Fijian employee at a major public institution told the that she used to have lunch with her Indian co-workers but that tradition ended with the 2000 coup.
} 
conciliation between the races is probably not possible with the institutional reinforcement of these social divisions.

\section{c.) The Distribution of Political Power}

Political competition in Fiji is ethnically bipolar. ${ }^{244}$ Almost all political parties are essentially ethnically-based and there is a strong ethnic basis for voting behaviour as well. Fijians tend to vote for nationalist parties such as the SDL and CAMV while Indians vote for the Labour Party or the NFP (though this vote evaporated in the last election). Bipolarisation is actually increasing as parties that traditionally had some multiethnic support (such as the FLP) are becoming increasingly ethnicised. Politics may be more conciliatory between elections but during election campaigns ethnic appeals and bipolarisation come to the fore. ${ }^{245}$ With the decrease in the Indian population (which has been reduced to a minority through emigration) the incentives for ethnic voting may decrease somewhat as the likelihood of the election of an "Indian" government decreases.

\section{d.) Distribution of Ecomomic Resources}

In Fiji perceptions of economic inequality have played a significant role in ethnic politics. The Indians are often portrayed as being wealthy and exploitative of poor Fijians. The veracity of this portrayal is questionable, but in ethnic politics perceptions can assume more importance than reality. Robertson and Sutherland contend that in the

\footnotetext{
244 See R.S. Milne, Politics in Ethnically Bipolar States, (Vancouver: University of British Columbia Press, 1981).

${ }^{245}$ Politicians in Fiji often tailor their words carefully to reflect the audience that they are speaking to. For instance, an Indian politician may attack Fijians and call for the need for Indian political unity to protect Indian rights against this "threat" when speaking to an Indian audience but may call for reconciliation and national unity when speaking to a Fijian or national audience.
} 
early 1990 s $79 \%$ of Fijians and $89 \%$ of Indians belonged to "disadvantaged classes."246 Indians did dominate the public service for many years but this is no longer the case. ${ }^{247}$ Moreover, most land in Fiji is owned by Fijians and this fact has helped to push many Indians to pursue education. ${ }^{248}$ Indians have continued to be more educated than Fijians but there are affirmative action programs in place to correct this. ${ }^{249}$

The visibility of Indians in the retail sector may have contributed to Fijian perceptions of Indian economic dominance. In June of 1987 only $15 \%$ of Fiji's seven hundred companies were Fijian-owned. ${ }^{250}$ Fijian participation in the economy has increased since then and today some of Fiji's largest companies such as the Hot Bread Kitchen and Fiji Holdings Limited are owned by Fijians.

There are various possible reasons for the failure of Fijians to thrive in the economy but probably the most important reason is the legacy of the colonial system which "limited their roles to that of workers, small-time buyers and sellers, and landlords."251 The Native Lands Trust Board (NLTB) and other government institutions have also undercut the economic leverage that could be gained by Fijian land-owners. Other factors may be the Fijian cultural system and communal values, which emphasise values such as giving ("kerekere") and the lack of capital available to Fijian

\footnotetext{
${ }^{246}$ Robertson and Sutherland 87 . Moreover, a recent study by the United Nations Development Program (UNDP) actually concluded that there is a slightly greater percentage of Indians than Fijians living in poverty.

${ }^{247}$ Robertson and Sutherland 88. Between 1987 and 1989 one thousand Indian public servants left and new appointments were at a Fijian-Indian ratio of three to one.

${ }_{248}$ Vijay Naidu, "An Indo-Fijian Perspective on Approaching Nation Building," The Goodwill Conference for Fiji (Suva, Fiji, 2002).

249 Robertson and Sutherland 89 . Between 1984 and 1999 only $11 \%$ of Fijians reached their final year in High School but $26 \%$ of Indian students did. There are still significant problems with the retention of Fijian students, of the 6252 Fijian students granted tertiary scholarships only $39 \%$ graduated.

${ }^{250}$ Robertson and Sutherland 89.

251 Robertson and Sutherland 92.
} 
entrepreneurs. Whatever the causes for Fijian underdevelopment, perceptions of economic inequality have contributed to the politicisation of ethnic identity in Fiji.

\section{e) Relative Demographic Strength}

In states with a high degree of ethnic politicisation demographic dominance and stability become primary aspects of political discourse. In Fiji, the immigration of Indians reduced Fijians to a minority and began to threaten their political paramountcy. After the Fijian nationalist coups of 1987 and 2000 many Indians have fled the country. The following chart illustrates population changes between 1986 and 1996 (the latest census):

Figure 4.1: Population of Fiji -1986 and $1996^{252}$

\begin{tabular}{|l|l|l|}
\hline & 1986 & 1996 \\
\hline Fijian & $322920(46.1 \%)$ & $393575(50.8 \%)$ \\
\hline Indian & $348704(48.7 \%)$ & $338818(43.7 \%)$ \\
\hline Rotuman & $8652(1.2 \%)$ & $9727(1.3 \%)$ \\
\hline European & $4196(0.6 \%)$ & $3103(0.4 \%)$ \\
\hline Part-European & $10297(1.4 \%)$ & $11685(1.5 \%)$ \\
\hline Chinese/Part-Chinese & $4784(0.7 \%)$ & $4939(0.6 \%)$ \\
\hline Other Pacific Islanders & $8627(1.2 \%)$ & $10463(1.4 \%)$ \\
\hline Other & $810(0.1 \%)$ & $2767(0.3 \%)$ \\
\hline Total & $715375(100.0 \%)$ & $775077(100.0 \%)$ \\
\hline
\end{tabular}


In 1987 Rabuka presented the Fijian nationalist view of the importance of maintaining a Fijian majority in Fiji:

My other hope is that the Indians will migrate. We tighten the controls, then Fiji is no longer attractive to the Indian settler as it has been for the last 120 years. Maybe they will slow down their immigration rate, probably increase their emigration rate, thereby having a natural decline in their numbers, to a level that would be manageable. When I talk about a manageable level I am talking about the tolerance threshold of the Fijians. Now it is beyond their tolerance level and that is why they are reacting, not because of the numbers but what the Indians can do with the numbers. If they gain control of the professional life, the economic life, and the political life of this country with the numbers they have, then the tolerance level, the numbers level will have to be greatly reduced. And we won't do that by a Butadroka kind of policy, forced migration, but by circumstances-driven migration. ${ }^{253}$

As the number of Indians continues to decrease, the "political security" of Fijians

increases as the identity of the state is no longer "contested." Subsequently one might expect that ethnic politicisation and polarisation will decrease.

\section{f.) Land Rights}

In Fiji control over the land is considered to be a fundamental right to be exercised only by indigenous Fijians. ${ }^{254}$ Fijians own $83 \%$ of the land in Fiji (by law). ${ }^{255}$ When Prime Minister Chaudhry attempted to make small adjustments to the land system he faced significant opposition. For Indians, land ownership has remained but a distant dream. Fijians, fearing a loss of control over the land, often invoke the examples of indigenous peoples losing their land rights in North America as well as Australia. It

252 Ralph R. Premdas, "Seizure of Power, Indigenous Rights and Crafting Democratic Governance in Fiji," Nationalism and Ethnic Politics, 8 (4): 19.

253 John Sharpham, Rabuka of Fiii, (Brisbane: Central Queensland University Press, 2000) 316.

${ }^{254}$ Naidu, "An Indo-Fijian..." 
would not be overstatement to say that land is the most important political issue to Fijians. Ties to the land are central to Fijian culture and traditional organisation. Land ownership remains a focal point of ethnic competition in Fiji, New Caledonia, and many other states experiencing ethnic conflict.

\section{g.) Historical Memory}

An ethnic group's history often shapes not only the form that nationalism may take but also whether politicisation occurs at all. In cases of defensive politicisation histories of marginalisation, violence, and exclusion can be rallying points for contemporary political mobilisation. History is equally important in cases of assertive politicisation where a group with a particular history of autonomy may seek to restore this autonomy. Such is the case in Fiji where Fijians base much of their political movement and demands on notions of indigenous entitlement. This indigenous entitlement is based on the assumption that, as the first people to inhabit the country, Fijians deserve an elevated position within the political, social, and economic life of the country. Fijians have always taken political control to be somewhat as a birthright as they view Indians as being a much more recent population that was introduced without the consent of the Fijians. Furthermore, Fijians have been denied their "righ" to construct a truly "Fijian" state. It is in this sense that Indians represent a "fly in the soup of nation-building" to ethnic Fijians.

Fijians have largely maintained a monopoly on political power in the postcolonial period and have constructed political and economic institutions to protect Fijian

255 Most estimates of Fijian land ownership are understated and date from the 1960 session of the colonial legislative council. According to USP researcher Vijay Naidu, Fijians own as much as $94 \%$ of the land in 
paramountcy. Moreover, whenever Indians have come close to gaining power (through the democratic process) Fijians have acted to subvert democracy in deference to the neotraditionalist model of indigenous paramountcy as embodied in chiefly authority. There are ties between indigenous Fijians and the global indigenous rights movement and indigenous nationalists such as George Speight have utilised the language of indigenous rights in defence of their political aims. Nevertheless, in contrast to other indigenous movements elsewhere Fijians have not been tremendously victimised by the state (see Chapter Five). Moreover, the nationalists' notion of indigenous rights is clearly much more far-reaching than that found in international legal instruments and it might be more accurate to label this approach as "indigenous paramountcy" rather than "indigenous rights." In spite of these issues, it is clear that contemporary Fijian nationalism embraces the notion of indigenousness (a notion grounded in historical memory) as a basis for the right not only to positive entitlements but a directive influence on the very nature of the state of Fiji.

\subsection{Non-Ethnic Factors and Ethnic Politics}

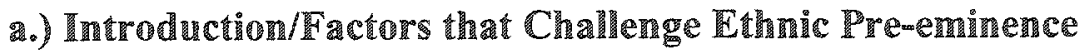

As noted in the previous chapter, political activity often transcends purely ethnic considerations. Despite this, ethnicity is often the primary force in identity politics and this is certainly true in the cases of Fiji and New Caledonia. It is difficult to isolate ethnicity from other aspects of identity as there are often crosscutting cleavages whereby ethnicity might be directly related to class or religion for example. The primacy of ethnicity among identity may also be diluted or displaced by other factors. Thus, non-

Fiji. 
ethnic factors may either reinforce the politicisation of ethnicity or even challenge ethnic primacy in political competition.

Primary among those factors that sometimes supplant the importance of ethnicity are regionalism and the related competition between Fiji's three traditional confederacies. Regionalism/provincialism is a powerful force in Fijian politics that has long historical roots. It was the Lau Islanders and Bauans who came to dominate the indirect governance structures in the British colonial administration. ${ }^{256}$ This dominance has continued in the post-colonial period and has been a source of much contention. ${ }^{257}$ There is also a sense of alienation in western Fiji that has been brewing for many years. It would not be overstatement to say that western chiefs were largely excluded from governance structures from the beginning of the colonial period until today. ${ }^{258}$ This western alienation has at times been a political force in Fijian elections.

Closely related to the issue of provincialism/regionalism is conflict between Fiji's three kingdoms (traditional confederacies). These traditional divisions still constitute an important identity field in Fiji and act as a source of conflict. The three traditional

\footnotetext{
256 The Western parts of Fiji were did not accede to British rule as rapidly as the eastern areas (such as Bau and Lau) and therefore the west was largely left out of the indirect governance deals that the British struck to facilitate their annexation of Fiji. The British declared the Bauan Chief Cakobau Tui Viti (King of Fiji). Christian missionaries were based in the Lau Islands early (1835) which meant that Lauans were among the first Fijians to receive a western education.

257 There are also significant differences between the eastern areas of Fiji, which have a greater Polynesian cultural influence and the west, which is more Melanesian. Eastern Fiji receives a disproportionate share of the wealth of the country even though most of the resources are located in the west. The west is also the source of the area of Fiji with the greatest population growth and population concentration. In spite of this, between 1984 and 1993 the budget allocation of Lau Province was the highest of all provinces $(10.6 \%$ of the total). Moreover between 1984 and 1994 Lau was allocated $19.83 \%$ of all overseas scholarships and $21.22 \%$ of local scholarships, (compared to $5.21 \%$ for Ba Province and $4.93 \%$ for Naitasiri). Eastern areas of Fiji also have a grossly disproportionate share of electoral power. For instance, there are an equal number of constituencies (two) for the populous province of Naitasiri (in the highlands) and sparsely populated Bua (in Vanua Leva). This means that a vote in Bua is worth five times more than in Naitasiri. ${ }_{258}$ The central highlands (colo or "hills") of Viti Levu, the Northwest, and the West were never a part of any of the three traditional confederacies and were simply annexed into other confederacies (mostly into Kubuna but also Burebasaga to a lesser extent) with the start of British rule (without the consent of the
} 
confederacies in Fiji are Kubuna (centred on the authority of Bau), Burebasaga (centred on Rewa in the village of Lomanikoro), and Tovata (led by the Cakaudrove chiefs and based in the village of Somosomo). These confederacies existed in some form before the $19^{\text {th }}$ century and British colonial rule. ${ }^{259}$ In much of the post-independence period Tovata has been dominant. ${ }^{260}$ The 2000 coup has been blamed on rivalry between Tovata and Burebasaga and seen as a reassertion by the Bauan chiefs of Burebasaga of their traditional role leading Fiji. In the period after the 2000 coup traditional and provincial politics were at the forefront as Fiji's paramount chiefs battled for the upper hand in the emerging post-coup Fiji. Regionalism and traditional affiliation are both significant political factors in Fiji and may displace ethnicity in times of lessening ethnic competition. $^{261}$

\section{b.) Non-Ethmic Factors that Reinforce the Politicisation of Ethnicity}

The main non-ethnic factors that reinforce the politicisation of ethnicity are religion and class (namely chiefs versus non-chiefs). The strongly Christian nature of Fijians may have actually increased ethnic bipolarisation in some ways as the differences between Indians and Fijians are represented as being more than just skin deep but

western chiefs). The traditional confederacies are important because representation in Fijian bodies such as the Great Council of Chiefs (Bose Levu Vakaturaga, or BLV) is allocated on the basis of confederacy.

259 Tevita Baleiwaqa, "Reflections on the Civilian Coup in Fiji." in Brij Lal and Michael Pretes (eds.) Coup, (Canberra, Australia: Pandanus Books, 2001) 25.

${ }^{260}$ Ratu Mara (paramount chief of Lau) had a long reign as the prime minister of Fiji and then as the president. The last Governor General of Fiji Ratu Sir Panaia Ganilau was a paramount chief of Tovata. Rabuka was also from Tovata and some commentators have argued that the 1987 coup was less about Fijian-Indian antipathy than the high chiefs of Tovata displacing a western-based government.

${ }_{261}$ In the Indian community there are also intra-ethnic divisions such as those between Gujaratis and nonGujaratis, and people of North Indian and South Indian origin. 
fundamental values. ${ }^{262}$ The spectre of Christianity is often raised among Fijian nationalist agitators who invoke fear among the Fijian population that Indians will take over the country and turn it into some kind of "heathen homeland."263 The Fijian nationalists also support the institutionalisation of Christianity in the Fijian State (Christianity is important in the nationalist movement as being the embodiment of the lotu in the Lotu-Vanua-Matanitu triangle). Religious conflict has also manifested itself in attacks on Indian holy institutions during times of ethnic tensions. ${ }^{264}$ Religious identity is a strong pillar of the Fijian nationalist movement's conception of Fijian identity and thus it has become politicised as a further source of ethnic differentiation. ${ }^{265}$

The division between the chiefly classes and commoners can also reinforce ethnic boundaries. Fijian nationalists are often conservative in their outlook and argue that chiefly authority is a fundamental part of Fijian tradition (which it is to some extent). Some have also argued that being a chief is or should be a prerequisite for holding such high offices as prime minister. ${ }^{266}$ Needless to say this would exclude Indians from these posts. Although the chiefs have increasingly sought status as a kind of pan-ethnic Fijian

\footnotetext{
${ }^{262}$ There are also intra-ethnic religious conflicts such as those between the Arya Samaj and Sanaatan Dirmi Hindu sects as well as, the evangelical "new" Christian churches and the older Christian churches. 263 I myself remember attending the Hibiscus Festival (Suva's city carnival) in 1998 and hearing a preacher at a public event shouting 'I don't worship Buddha! I don't worship Shiva! I don't worship Allah! I don't worship Ali Baba! I don't worship Hubba Bubba! There is only one God!" What makes this most remarkable is that at a public event a religious demagogue was denouncing and ridiculing the beliefs of half the population! Unfortunately, this is not uncommon in Fiji. Mahendra Chaudhry has been compared to Satan several times in a major national newspaper!

${ }^{264}$ Naidu, "An Indo-Fijian..." For example, between June 1996 and March 2002 twenty-three mosques and temples were desecrated. This included acts of arson such as the burning of holy books, as well as, the smashing of statues of gods, and human excrement being spread on the floor and walls.

${ }^{265}$ See Chapter Six for a further discussion of the role of religion, especially Methodism, in the Fijian nationalist movement.

${ }^{266}$ The 1987 coup is sometimes described as being fuelled by the inability of the ruling class to accept a commoner (Timoci Bavadra) as prime minister.
} 
institution, clearly this is not the case. The strengthening of chiefly authority is often held up by Fijian nationalists as essential to maintaining Fijian paramountcy.

\subsection{Conclusion}

Fiji is an ethnically-bipolarised state where two ethnic groups (Indians and Fijians) dominate political competition. This bipolar competition supplants not only other ethnic groups but also other non-ethnic identity fields such as religion and regionalism. Ethnic identity has been institutionalised and reinforced by the state. Fijian politicisation is fundamentally a product of Fijians' desire to exercise control over the state. This desire for control includes such elements as land ownership, political power, as well as building a national identity centred on Fijian institutions (such as Christianity and chiefly power). Therefore, Fijian politicisation is primarily assertive and does not match Crawford and Lipschutz's causation for the politicisation of ethnicity (namely hardship and marginalisation). 


\section{Governing Elites and the Politicisation of Ethnicity}

\section{Introduction}

Elites play a primary role in the politicisation of ethnicity. Where certain conditions are present (such as political and economic inequalities) ethnicity is an available means both to access and to maintain control over state power. These governing elites both create the conditions necessary for the politicisation of ethnicity, as well as utilise ethnicity in order to gain a political constituency. Elites can display ideological and/or entrepreneurial characteristics. ${ }^{1}$ Ideological elites are driven primarily by ideology. The mobilisation of ethnicity by ideologues may be particularly dangerous as demands are often inflexible and therefore less likely to be accommodated. ${ }^{2}$ In contrast, entrepreneurial elites use ethnicity as a means to mobilise political support and maximise their benefits. In order to garner this support they need to not only invoke their commonality with their constituency but to offer some sort of implicit or explicit guarantee that they will protect the interests of the group. Often leaders actively seek out their constituency by stiring up fears and by attacking other groups; 'if you don't vote for me your survival as a group is threatened' (defensive politicisation). There can also be a more coercive aspect to this appeal: 'if you vote for them you are betraying $a s$. ' Intra-group competition may also be limited by entrepreneur calls for group cohesion

\footnotetext{
1 These categories are not mutually exclusive.

2 Racial/ethnic ideologues may undertake a genocide the attempt to destroy an identifiable group in whole or in part) or irredentism (an ideology which seeks to unite all members of a particular group within the same political space).
} 
in the face of external threats. Ethnic entrepreneurs are, by definition, almost always "well-placed individuals."269

This power of governing elites is often reinforced through clientelist networks.

Within the survival discourse and fears of the dominance of "6the other" a nexus of interests between an individual voter and a leader from the same ethnic group is almost certainly present. As Clapham wrote,

One of the strongest, most alluring, and at the same time most dangerous forms of clientelism is the mobilisation of ethnic identities... From a political viewpoint, ethnicity may be seen as a means for giving a moral bond or cement to a clientelist network. The party leadership is placed under an obligation to look after the interests of its constituent race, tribe, caste or religious group; equally to the point, the leadership acquires a kind of legitimacy as the authentic representative of that group, regardless of the enormous differences of class and wealth, and in some respects of political interests, between it and its followers. Clientelism, which depends for its existence on a hierarchically ordered society in which class differences are often intense, both serves as a mechanism for maintaining ruling class interests and, at the same time, systematically inhibits the articulation of classes as a source of overt political conflict. ${ }^{270}$

This use of ethnicity by ethnic entrepreneurs as a means of building cohesion in a clientelist network is very apparent in both our cases.

Instrumentalists such as Crawford and Lipschutz place a great deal of focus on the role of ethnic entrepreneurs in the politicisation of ethnicity. As stated in Chapter One, instrumentalists view ethnic groups largely as interest groups. In other words, the pursuit of political power provides incentives for ethnic cohesion. Crawford and Lipschutz's vision of the politicisation of ethnicity is particularly state-centric because it assigns much of the power for the politicisation and depoliticisation of ethnicity to the state. The

\footnotetext{
${ }^{269}$ Lipschutz 70.

Alumita Durutalo, Provincialism and the Crisis in Fijian Political Unity, MA Thesis, University of the South Pacific, December, 1997: 128.
} 
pursuit of state power is an essential ingredient to the politicisation of ethnicity in that politicised ethnicities are, by their very nature, engaged in political competition to this end. Once a particular leadership cadre has utilised ethno-political discourse to gain power it is reluctant to relinquish ethnic politics as the basis for its political control. Thus, governing elites seek the continued politicisation of ethnicity as a means to secure their position. As Rene Lemarchand argues:

The essential point to note is the centrality of the state both as an instrument as group domination and as an arena where segments of the population compete among themselves to gain maximum control over patronage resources. So from this perspective the state, far from being a mere abstraction, emerges as a cluster of individual contestants and cliques actively involved in the struggle for control over the party, the army, the government, the civil service, and parastatal organisations...Access to the state thus becomes a source of potential rewards for some groups and deprivations for others. ${ }^{271}$

It is in this way that governing elites contribute to the politicisation of ethnicity.

This chapter will build on previous chapters (which examined the conditions that allow the politicisation of ethnicity) and examine how and why governing elites encourage the politicisation of ethnicity. Both Fiji and New Caledonia have elites that have controlled the state for many years and utilised ethnic politics to reinforce their power. In New Caledonia this elite is primarily European while in Fiji it is primarily Fijian. The fact of Fijian state control in Fiji further refutes Crawford and Lipschutz's argument that the politicisation of ethnicity is grounded in marginalisation.

\subsection{Governing Elite in New Caledonia: The RPCR State}

In New Caledonia a collusion of interests has dominated political and economic

${ }^{271}$ Lipschutz 69. 
life since the colonial period. These interests are primarily economic and are shared by the French State and the European settlers in New Caledonia. The power and privileges of this elite will be threatened if the Kanak nationalists' goal of Kanak socialist independence becomes a reality. The elite resists Kanak nationalism both through democratic politics and the direct coercive intervention of the French State.

In New Caledonia a colonial bourgeoisie developed around Nouméa. ${ }^{272}$ The great Caldoches families that prospered during the colonial period, such as Ballande, Lafleur, Pentecost, Barreau, and others continue to be very powerful today. ${ }^{273}$ The influence of these families is extended through "complex networks of patronage." ${ }^{3274}$ They control key sectors of the economy such as nickel (Lafleur), retail (Ballande and Barreau), and import-export. ${ }^{275}$ The ties between the Caldoches economic elite are further tightened through interlocking shareholding arrangements. ${ }^{276}$ This Caldoche elite has also formed alliances with Métros in the economy and administration.

This small elite which dominates the commercial sector in New Caledonia is also politically dominant. For instance, Roger Laroque is the Mayor of Nouméa and chair of the RPCR Party, as well as being a major shareholder in Ballande and other companies. Moreover, Jacques Lafleur is not only the richest man in New Caledonia but also the

\footnotetext{
272 Maclellan and Chesneaux 146. Nouméa is often compared to a provincial city in France, with a weak civil society and a lack of alternative views.

273 Maclellan and Chesneaux 146.

274 Maclellan and Chesneaux 146.

275 Maclellan and Chesneaux 146 and Connell 128-150. Some of these wealthy families (such as Ballande and Lafleur) made their fortune as the petits mineurs who founded corporations such as the Sociéte Minière de Sud Pacifique (SMSF). The Lafleur family owns a 70\% share of this company. With the nickel boom of the 1970's came a boom in commerce and local merchants such as Etablissement Ballande and Maison Barrau in particular benefited. Ballande is also heavily diversified with investments not only in mining but in coffee manufacturing, shipping, sawmilling, metal working, wine bottling, and clothing. Ballande and Lafleur also own two of the largest cattle stations in New Caledonia.

276 Connell 150.
} 
leader of the RPCR (and president of Southern Province). ${ }^{277}$ The RPCR Party is the main political tool of this elite although there is also a radical fringe with allegiance to the extreme right. ${ }^{278}$ Further cementing the power of this cadre is their control over the media. ${ }^{279}$ Moreover, the Catholic Church hierarchy in Nouméa also has close relations with the RPCR. ${ }^{280}$ This confluence of interests, often under the direct influence of Paris, is what some commentators have labelled the "RPCR State."

It is in the best interests of the RPCR State that the Kanaks remain politically and economically marginal. The RPCR State has failed to adequately distribute the benefits of the mineral wealth of New Caledonia and has instead passed profits on to a narrow group within its clientelist networks. The economy is a model of dependency and corruption and is built on the flow of New Caledonian raw materials outside of the country and the importation of French goods. It is difficult to find anything made in New Caledonia in an average store. This artificial economy has the effect of concentrating power in the hands of a few individuals. As one Chinese-Tahitian shopkeeper in Nouméa argued: "They own everything. Do you see this piece of gum? They own this. Do you

\footnotetext{
277 Maclellan and Chesneaux 149.

278 Ultra-right groups such as the Front National and Front Calédonien are known for their racial appeals and are active in New Caledonia. The employers' federation the Federationa Patronale des Moyens Enterprises (FPME) has connections with the extreme right and has used militants in clashes with the police and striking workers. In April of 1996, seven members of the anti-independence Dijou Group (named after their leader) were convicted for committing fourteen burglaries between 1988-1993. In March of 1994 arms caches were uncovered at Ducos and Ouemo including guns, explosives, and blank passports that had been stolen in October 1991 from the Immigration Office of the French high Commission. For these extremist groups the prospect of an independent New Caledonia led, at least in part, by Kanaks holds little appeal.

279 Les Nouvelles Calédoniennes is New Caledonia's main daily paper and it often takes a very conservative view which could be said to be virtually synonymous with the RPCR's political stance. Radio et Télévision Français Outre-Mer (RFO or French Overseas Radio and Television) is funded by the French government and unsurprisingly its broadcasts in New Caledonia are heavily biased in support of the position of the RPCR and France.

${ }_{280}$ Despite this many Kanak leaders have also come from the church such as Jean-Marie Tjibaou, Eloi Machor, Appollinaire Ataba, Franco Burck, and Alphonse Dianou.
} 
see the newspaper? They own that. It is so comupt here it makes me sick."281 The Kanak nationalists have led the challenge to the power of the RPCR State and have forced changes to the structure of the government and economy. There are also those within the Caldoche community who resent the power of the RPCR elite and have sought to challenge it. ${ }^{282}$

Throughout the history of New Caledonia the RPCR elite is largely responsible for the marginalisation of the Kanaks in the economy and political system. The power of this elite was built on the backs of the Kanaks. Kanak land was stolen for the RPCR State's economic activities such as cattle ranching and nickel mining. The RPCR State governing elite has contributed significantly to the Kanak marginalisation that forms the basis for the defensive politicisation of Kanaks.

\subsection{Goverming Elite in Fiil: The Military-Traditional Complex}

\section{a.) Introduction: Tradition and Traditionalism}

As in New Caledonia, in Fiji ethnicity is utilised by a small elite in defence of its political and economic privileges. This elite embraces the notion of a return to Fijian traditions. It is important to distinguish between tradition as a matter of culture and traditionalism as a political ideology. The traditionalist political ideology is built on a rigid conception of tradition while cultural tradition itself is a dynamic force. The traditionalists have advanced a very particular and conservative vision of what "tradition" means in the Fijian cultural context. Ratu Mara labelled this approach to politics as the "Pacific Way". It emphasises the "virtues of stability, tradition, and by implication...the

\footnotetext{
281 Conversation with Chinese shopkeeper in Nouméa August 2002, translation mine.

282 The Alliance Party is one such group.
} 
value of traditional "chiefly rule," in contrast to Western political values. ${ }^{283}$ The irony of traditionalism is that it often seeks to strengthen the European reinvention of tradition rather than pre-colonial tradition itself. ${ }^{284}$

In Fiji it is often argued that allegiance to the ruling class is necessary for protection of Fijian ethnic interests. Sociologist Epeli Hau'ofa argues:

It is the privileged who can afford to tell the poor to preserve their traditions. But their perceptions of which traits of traditional culture to preserve are increasingly divergent from those of the poor, because in the final analysis it is the poor who have to live out the traditional culture; the privileged can merely talk about it, and they are in a position to be selective about what traits they, use or more correctly urge others to observe; and this is seen increasingly by the poor as part of the ploy by the privileged to secure greater advantage for themselves. ${ }^{285}$

In other words, the main proponents and beneficiaries of traditionalism are the elite.

Fijian identity, as defined by the indigenous nationalist movement, is becoming increasingly exclusive. This identity is often presented as being centred around three things: the lotu (church), matanitu (state), and vanua (land, cultural tradition). There are two important aspects to this concept: 1) the everyday importance that most Fijians place on these institutions; and 2) the normative aspects of this argument as a societal ideal. Anyone who challenges this view will be told that they are attacking Fijian tradition itself. Reverend Ina Maroi explains:

283 Stephanie Lawson, Tradition Versus Democracy in the South Pacific: Fij, Tonga, and Samoa, (Cambridge: Cambridge University Press, 1996) 2-4. The romanticism of the Pacific traditionalists is comparable to other "cultural revival" movements elsewhere in the world. One example of this is the Africanisation movement which sought a return to an Africa that may have never existed. According to James Clifford the Africanisation Movement was "a backward-looking idealism, a falsely naturalised, consistent African mentality that tends to reinscribe the categories of a romantic, sometimes racialist European ethnography."

${ }^{284}$ For instance, institutions such as the Bose Levu Vakaturaga (Great Council of Chiefs) and the Fijian Administration were created by the British but have now been embraced by Fijian traditionalists as being fundamental to Fijian tradition.

285 Lawson 4. 
The vanua was always there. The land, the people and their chiefs. They had their own culture, language, food...they had names on the land, trees, birds, and animals, different names for days and months. The lotu was the second to arrive in 1835, she preached the gospel of Jesus Christ and the vanua was transformed. The matanitu was built by the vanua through the advice of the Methodist missionaries. Fijian culture and values are being eroded by ignorant alien politicians because they promote individualism, they attack the Fijian race because of the way they live communally...All real Fijians had three loyalties to consider and oblige in joy. The first to the vanua, second to the lotu and the third to the matanitu. ${ }^{286}$

The elite that controls these institutions also controls the institutions of the state.

The Fiji Military Forces (FMF) is an almost exclusively Fijian institution that has often viewed itself (and been viewed by Fijians) as a defender of traditionalism. Furthermore, the chiefly elite is synonymous with the leadership of the Methodist Church, the Fiji Military Forces, and the Fijian political leadership. This network of elite interests is what I have dubbed the military-traditional complex. ${ }^{287}$ My militarytraditional complex refers to the intertwined relationship between the various forces of traditionalism (such as the Methodist Church, the eastern chiefs, the Fijian Administration, and the Fijian military). ${ }^{288}$ This military-traditional complex has sought to "ethnicise" political discourse and state institutions in order to protect its political and economic power. ${ }^{289}$ This section will analyse each aspect of the military-traditional complex and how this governing elite contributes to the politicisation of identity.

\footnotetext{
286 Reverend Ina Maroi, "Fijian Social Structure," (letter to the editor), Fiii Times, Sunday, October 6: 10. Maroi wrote this letter in response to Mick Beddoes (the leader of the General Voters Party) who criticised the Soli ni Yasana (provincial levies) and the Soli ni Lotu (church levies). Maroi argued that by questioning the Soli, Beddoes was threatening to "destroy Fijian social structure."

${ }_{287}$ This is a play on President Eisenhower's "military-industrial complex," which described the intertwined relationship between the government, armed forces, and arms industries.

${ }_{288}$ The military-traditional complex in Fiji was partially constructed by the British in order to facilitate their indirect rule. Please see Chapter Two.

${ }_{289}$ The 2000 coup can also be attributed at least in part to political manoeuvring by those within this elite.
} 


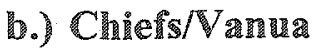

You cannot be a Fijan if you do not observe the hierarchy of the structure of the Tauke society. - Sitiveni Rabuha 290

Fijian ethnic identity has become intrinsically linked to class identity. At the core

of the political ideology of the Fijian nationalists/traditionalists is the idea that the

political loyalty of Fijians not only belongs with ethnic Fijians but the chiefly class.

Senator Ratu Inoke Tabua (an appointee of the BLV) asserts: "the chiefs represent the

people, the land, the customs. Without a chief there is no Fijian society. When Fijian

chiefs are attacked or criticised in whatever capacity - personal or political - it is the

Fijian vanua which is also being criticised. ${ }^{.9291}$ Thus, Fijian nationalism has not only

become synonymous with ethnic identity (Fijian) but also class identity (chiefly). ${ }^{292}$

The military-traditional complex uses Fijian fears of Indian domination to

reinforce its own power. For example, in June of 1987 Ratu Ganilau's Council of

Advisors issued the following statement:

Democracy and its ideas of liberty and equality of life are not appropriate to the situation in Fiji...they are contrary to the Fijian way of life where

\footnotetext{
290 Sharpham 319.

291 Lawson 62. Bavadra repudiated this view when he argued: "a chief, be he ever so high in the traditional system, does not have frve votes where his people have four... In previous elections, the alliance fear tactic used to include asking people whether they wanted an Indian Prime Minister; now...the leader is a Fijian, so the question is whether a non-chief should be Prime Minister... One could thus imagine that if an equivalent chief from another province challenged Ratu Sir Kamisese Mara, the Allance question would be: 'can we let a Prime Minister of Fili come from any province but Lau?" Please see Chapter IV for a further discussion of provincialism.

292 Lawson 61 . The Alliance party often used chiefly connections to bolster their legitimacy. In the 1982 elections the NFP distributed a videotape of an Australian television program. The voice over to the program said: "Britain bequeathed the Westminster system of government to Fiji and it has worked for the twelve years since independence in spite of the lingering remains of an old feudal system: government by the descendants of the Great Chiefs who clubbed and ate their way to power in these islands centuries ago. The democratic chief of Fiji for the past twelve years is such a descendant. A Ratu, a chief, and a knight too, Sir Kamisese Mara." This attack on the chiefly system was used by the Alliance to great affect in building cohesion around its coalition.
} 
liberty exists only within one's social rank and equality is constrained by a fully developed social hierarchy. ${ }^{293}$

The call to tradition serves a dual purpose: 1) it is a covert attack on Indian values and a call for Fijians to unite against this 'alien' presence, and 2) it is a means for Fiji's ethnic entrepreneurs to undermine their critics (both Fijian and Indian) and maintain their power. As the Roko Tui Bau Ratu Jone Madraiwiwi argues, there is "a particular group of Fijians" who use calls for Fijian unity as "an excuse to keep themselves in power."294 The chiefs consistently issue the message that "Fijians must unite so they can conimue to wield political power."295 These calls for unity are "a deliberate and urgent attempt [by the chiefs] to defend their status as the only 'defenders and promoters' of ethnic Fijian interests and aspirations." ${ }^{., 296}$ In promoting "ethnic Fijian interests and aspirations" the chiefs are also promoting the assertive politicisation of Fijian ethnicity.

The coups in 1987 and 2000 can also be seen in this light - class interests are presented as being ethnic interests. ${ }^{297}$ The chiefs have sought to institutionalise this version of identity in the state. Samisoni Tikoinasau, a Member of Parliament from the Conservative Alliance Matanitu Vanua Party (CAMV), argues that Fiji should "go back to traditional confederacies" in order to "minimise the threat of control getting out of our

\footnotetext{
293 Lawson 171.

294 Robertson and Sutherland 133. To make this argument is not to suggest that everyone who values Fijian tradition is politically motivated. We must return here to the distinction between the politicised version of tradition espoused by traditionalist political leaders and the cultural notion of tradition that exists in every Fijian family in every community in Fiji.

295 Ratu Jone Madraiwiwi, "Fiji's 2001 Elections: Our Country at the Crossroads," in Kim Gravelle (ed.), Good Governance in the South Pacific, (Suva, Fiji: University of the South Pacific, 2001) 13.

${ }_{296}$ Durutalo 144.

${ }^{297}$ Robertson and Sutherland 117. The presentation of the chiefs as an august council has been put forward by some in attempts to imbue the body with a sort of pan-ethnic, "national" identity and legitimacy.
} 
hands," and that the power of the chiefs "must be legislated." 298 The presence of the Indian "threat" actually has the effect of strengthening the power of the chiefs. ${ }^{299}$

After Rabuka's coup in 1987 the military-traditional complex and chiefly power were strengthened: "The turaga [chiefs] and the vanua were one. One could not exist without the other - the chiefs were a bulwark of security for all and custodians of Fijian identity, land and culture. ${ }^{, 300}$ Many chiefs also supported the coup and a chiefly party (the SVT) was created to cement their power. ${ }^{301}$ The SVT is ideologically charged with championing and defending the ideals of the neo-traditionalists. Moreover, the 1990 constitution sought to advance the interests of rural and eastern Fijians - those deemed most likely to support and protect the military-traditional complex. ${ }^{302}$

The chiefly classes in Fiji are not only dominant in the traditional sphere but also in modem politics, the military, and other areas of life in Fiji. Furthermore, the upper echelons of this chiefly class are bound together not only by their noble birth, but also by their education. Fiji has traditionally had two elite schools: the Adi Cakobau School (ACS) for girls, and the Queen Victoria School (QVS) for boys. Both of these schools

\footnotetext{
298 Speight.

299 Sharpham 315 . The formation of the SVT by the chiefs was accompanied by much rhetoric about the need for Fijian unity around the chiefs in order to stave off the threat of Indian dominance. Rabuka argued: "The Great Council of Chiefs can unify the Fijians. If they say, "now you political leaders come here - we want you all to form a single party, call yourself whatever you like, appoint a new leader, get an executive and get together in the interest of the Fijans and we will support that pary as the Great Council of Chiefs; it can be done. Some senior chiefs will oppose it, seeing it eroding the fundamental rights and freedoms of the indigenous Fijian. What is more important - his fundamental individual right or the survival of a race?" 300 Lawson 50 .

301 Robert Norton, Race and Politics in Fiji, Australia: Queensiand University Press, $1990: 145$ and Sharpham 314. As Rabuka himself said, "I was adopted as one of their own by the Great Council of Chiefs for my role in the military coup in May [1987], and for returning power to Ratu Penaia in Decenber..." A though Rabuka was a commoner, he was connected closely to at least wo of the four pillars of the military-rraditional complex - the Army and the Methodist church. Rabuka also attended the chosen educational institution of the chiefly establishment, Queen Victoria School (QVS). But even as Rabuka increased the power of the chiefs he also increased the power of the radical Taukei movement, of which many of its leaders were of low or intermediate rank.

302 Lawson 67 . The constitution was "the institution of a system that attempts to guarantee the permanent dominance of a single political group destroys one of the most basic features of modern democracy."
} 
were created by the British for the purpose of educating the indigenous elite and grooming them for their role as agents for British indirect rule. In the post-colonial period these aristocratic graduates continued to think of themselves, and be thought of by others, as the leadership cadre of Fiji. ${ }^{303}$ QVS and ACS are the educational institutions of the Fijian elite and therefore both are part of the military-traditional complex.

There are some indications that the power and influence of the elite chiefs has declined in recent years. After the 1992 elections only seven of the thirty Fijian members were Ratus. ${ }^{304}$ Moreover, in the 1999 elections, two-thirds of Fijians voted against the party of the chiefs (SVT) ${ }^{305}$ Nevertheless, this can be misleading because most Fijians still voted for parties dominated by the chiefly elite. Many commentators also interpreted the post-2000 coup chaos in Fiji as being an indication that commoners no longer respected the authority of the chiefs. Nevertheless, it was the Great Council of Chiefs who eventually chose an interim Prime Minister for Fiji (with the consent of the military). Furthermore, Prime Minister Qarase's government has actually sought to increase the power of the BLV by giving them an independent budget (with increased financing) and building a headquarters complex in Suva. Qarase has justified these moves by arguing that:

\footnotetext{
303 Sharpham 84 and 110 . It was at a 1987 QVS Old Boys (alumni) meeting attended by Rabuka that some of the discontent surrounding the election of the Bavadra government was aired. At the meeting Rabuka argued: "We have to be more than a club where we all get together and get drunk or drink grog [Yaqona]...the school we went to is supposed to be the one to train future leaders. I believe we need to do more than concentrate on the social side of our association. We must work towards having this club as the core of a new political grouping to shape the Fijian leadership of the future." The QVS Old Boys have largely shaped Fijian leadership. The network of Old Boys includes Filipe Bole (a Rabuka Cabinet Minister and one time ambassador to the USA), as well as cabinet ministers, Jonetini Kavimoce, Lagisoa Delana, Viliame Cavobati, and former army commander Paul Manueli. It also includes High Commissioners Filkimore Jitiko and Ratu Isoa Gavidi, business leaders Jonetami Galuinadi (Fiiji Sugar Corporation), and Joe Mar Bainivanua (Shell Australia), and Serupepeli Nagasi (Fijian Affairs). Police Commissioner Isikia Savua and Cabinet Secretary Jioji Kotobalavu are also Old Boys.

304 Lawson 73-75. It is difficult to ascertain how much Fijians value the current chiefly system because open criticism of the chiefs and the traditional hierarchy violates Fijian custom.
} 
Chiefs derive their legitimate authority from their position in the indigenous Fijian social hierarchy from time immemorial and which was confirmed in the recognition given to them in the Deed of Cession, 10 October 1874. This gives the Great Council of Chiefs legal superiority and the right to appoint governments. ${ }^{306}$

The BLV is increasingly acting as a third chamber of parliament. ${ }^{307}$ Tikoinasau describes it as "a separate body that oversees the whole running of the country."308 The chiefly oligarchy plays a crucial role in the military-traditional complex. The chiefs are the leadership cadre that dominates indigenous Fijian politics. Moreover, this leadership cadre has utilised the ethnic discourse to gain and hold its power and in doing so has contributed to the politicisation of ethnicity.

\section{c.) Methodist Church/Lotu}

The Methodist church has a very powerful political, social, and cultural presence in Fiji. It has come to be regarded as a part of Fijian tradition (as well as other Christian churches to a lesser extent) and as one of the three pillars (as the Lotu or "church") of Fijian society. The church itself may have played a direct role in the 1987 coup. ${ }^{309}$ Meetings plotting the coup were held in the offices of the Methodist Church. ${ }^{310}$ Alliance Party Candidate Gonelevu gave a religious justification for dissatisfaction with the Bavadra government, "This government will not be a Christian government. We will be

\footnotetext{
305 Robertson and Sutherland 125.

306 Robertson and Sutherland 123.

307 Madraiwiwi 10.

308 Tikoinasau and Norton 151. At the very least the chiefs retain a strong "cultural power of legitimation."

309 Before the coup, an important meeting was held between Viliame Gonelevu (an Alliance Party candidate), Ratu Inoke Kubuabola (President of the Fiji Council of Churches and an Allance Party campaign manager) and Jone Veisamasama (Secretary General of the Alliance Party).

310 Sharpham 96.
} 
controlled by a government that does not have a Christian point of view. itself argues, "what Rabuka did accorded with God's plan.",312

Even the administrative structure of the church is based on the Fijian traditional system with its "circuits" corresponding closely to vanua. ${ }^{313}$ Chiefs are given a privileged place within the church with special pews in village churches often reserved for them. Furthermore, "prayers are often offered in Methodist churches seeking God's assistance in protecting and strengthening local chiefs...these are chiefs by commandment of God." ${ }^{314}$ This bestows a kind of unassailable authority on the chiefly aristocracy. There is a mutually reinforcing relationship between the chiefs and the church as there is between all institutions in the military-traditional complex.

There is some evidence that the power of the Methodists is weakening in Fiji Fijians are leaving the Methodist church for the new churches. Some have attributed this to leadership problems while others argue that the politicised church suffered from the failure of the 1987 coup to deliver results for indigenous Fijians. ${ }^{315}$ There have been recent moves to depoliticise the church but it will retain a powerful political role unless it

311 Sharpham 96.

312 Norton 139.

313 Nayacakalou 92.

314 Nayacakolou 113.

315 Williams and Saksena 25. 
divorces itself completely from the institutions of the state. ${ }^{316}$ The lotu still has a strong effect on group identity and remains "an agent for political change and control."317

\section{d.) Matanitu/Fijian Administration}

The Fijian Administration is the entire administrative structure responsible for Fijian development and governance. ${ }^{318}$ It includes such things as the Native Lands Trust Board (NLTB), the Fijian Affairs Board (FAB), the BLV (Bose Levi Vakaturaga or Great Council of Chiefs), and the provincial system. Quasi-government institutions such as Fiji Holdings Limited (FHL) and Yasana Holdings Limited are private sector elements of the Fijian administration.

The Fijian administration also represents the institutionalisation of identity in a certain form. The matanitu is closely tied to chiefly power and "to criticise the chiefs was to criticise Fijianness itself, and that now includes their institutions such as the Great Council of Chiefs, the Native Land Trust Board, even Fiji Holdings Ltd." ${ }^{\text {319 }}$ Alumita Durutalo contends that the traditional system in Fiji amounts to a clientelist network. ${ }^{320}$ When the colonial power built the institutions of indirect rule they were also building

\footnotetext{
316 With the election of Reverend Tuwere as president of the church in October of 1995 reforms came about such as reduced membership levies, no Sunday ban, inter-denominational services, and better management of the church's finances. An example of the ties between the state and the church is that recently the Metbodist Church built an office building in Suva and the government immediately offered to rent the entire building. There have been questions as to whether the government really needed this space or was in effect, giving an indirect subsidy to the church through its rents. Moreover, the BLV and some of the provincial councils also have proposals for office buildings which the government has also committed itself to renting. This is an interesting example of the close relationship between the institutions of the military-traditional complex.

317 Williams and Saksena 26.

318 The Fijian adminisiration is another creation of the British colonial government that has now come to be seen as an important part of Fijian tradition.

319 Robertson and Sutherland 117 .

${ }^{320}$ Durutalo 49.
} 
patron-client networks. ${ }^{321}$ There was (and is) a synergy between traditional authority and government administration. ${ }^{322}$

A large amount of the government funds allocated for Fijians are controlled through the Fijian administration. The control over these funds reinforces the power of the military-traditional complex. One of the most important powers exercised by the elite is the distribution of land rental income. Under the current system the land rents are distributed as follows: twenty-five percent to the NLTB; five percent to the vanua chief (turaga ni vanua); ten percent to the yavusa chief (turaga ni yavusa), fifteen percent to the mataqali chief (turaga ni mataqali); and the remaining forty-five percent to the rest of the mataqali (commoners). ${ }^{323}$ Thus, regular Fijians actually receive very little of the profits from their land ( $45 \%$ divided amongst the entire community) and much of these profits return to the military-traditional complex.

Fiji Holdings Limited is a corporation created by the BLV in 1984 in order to "increase Fijian participation in the commercial economy...through the acquisition of established, well-managed, profitable companies with excellent prospects for growth...[and to ensure that the] benefits spread as widely as possible among the Fijian people." 324 However, there has been a lack of 'trickle-down' to the poor and by the early 1980s the failure of communal capitalism to alleviate poverty became obvious. ${ }^{325}$ The NLTB and FAB hold $27 \%$ of the FHL shares, while private companies, tikinas [districts], and mataqalis hold the rest. The problem with this system is that before any money can

\footnotetext{
321 Local leaders in the provincial system may become 'middle men' in patron-client relationships.

322 Durutalo 91 . For example, $92 \%$ of Buli's (district government officials) were traditional chiers.

323 Durutalo 116. Nomally the Turaga ni Vanua is also the Turaga ni Yavusa and Turaga ni Mataqal:, and therefore they receive thity percent of land rentals.

324 Steven Ratuva, Ethnic Politics. Communalism, and Afrmative Action in Fin: A Critical and Comparative Study, (MA Thesis, Institute of Development Studies, University of Essex, 1999) 211.

325 Robertson and Sutherland 95.
} 
reach average Fijians, it is skimmed by the administrators and leaders of the militarytraditional complex. The NLTB has done a poor job of handling the money of Fijians, often being accused of corruption, and nearly hitting bankruptcy in 1997.326 The NLTB is itself politicised and in 2000 the director of the NLTB was very vocal in his criticism of the Chaudhry govermment. Ratuva argues that the NLTB represents "narrow, parastatal, bureaucratic and private institutional interests, propagated as universally ethnic Fijian."327 Furthermore, NLTB shares in FHL are "an entrepreneurial engagement that advances this narrow interest., 328

FHL is funded by money raised by the provinces and tax money used by the FAB to purchase shares. Individual investors are limited to a maximum of $\$ 10000$ and must be ethnic Fijians. Most shares are held communally through the NLTB, Fijian Development Bank (FDB), the provincial councils, and tikina councils. The $73 \%$ of shares not owned by the NLTB and FAB are owned mostly by the Fijian elite. ${ }^{329}$ There are also many allegations of corruption and insider trading in relation to Fiji Holdings. ${ }^{330}$ Clientelist networks developed around the parastatal structures of the Fijian Administration and some argue that Rabuka's 1987 coup "also represented a rising group of business people and technocrats who deeply resented the loss of patronage the change in government represented."331 The same was true for the 2000 coup where Chaudhry may have alienated some interests by moving quickly once in office to cancel many improperly tendered contracis. There are also allegations that George Speight (the CEO

326 Robertson and Sutherland 96.

327 Robertson and Sutherland 96.

328 Robertson and Sutherland 96.

329 Robertson and Sutherland 98.

330 Ratuva 216.

331 Robertson and Sutherland 80. 
of Fiji Hardwood before Chaudhry dismissed him) was set to receive major kickbacks from an American company involved in bidding over Fiji's extremely valuable mahogany plantations.

Prime Minister Qarase's Blueprint for Fijian Development follows this same model of bureaucratic, top-heavy development. This blueprint includes such elements as increased funding and loans for FHL, the NLTB, and provincial councils. One has to wonder if the so-called Blueprint for Fijian Development is designed to empower impoverished rural Fijians or simply to secure the bureaucratic strongholds of the Fijian elite? Nayacakalou echoes these sentiments when he asserts that Fijians told him that the declared policy of development within a traditional framework is "deliberately preached by the chiefs to keep themselves in a privileged position." ${ }^{332}$ He also argues that if changes are made to the Fijian administration that some chiefs will object to the loss of their "favoured treatment in the...distribution of salaried posts," and that "local chiefs... have a vested interest in the preservation of the Fijian "way of life." 333 Furthermore, an earlier investigation into the Fijian Administration concluded:

The effects of the Fijian Administration on the economic growth of the Fijian people have been little short of disastrous, and the source of much of the difficulty lies within the structure and philosophy of the administration as a political unit...[appointments] leaned heavily on the side of family position and benign paternal, even aristocratic authority. ${ }^{334}$

Steven Ratuva argues that "the deployment of communal capitalism" in Fiji has "restricted the development of individual entrepreneurship.,335 The belief that the

\footnotetext{
332 Nayacakalou 136.

333 Nayacakalou 138 and 135.

334 Robertson and Sutherland 70.

335 Ratuva 197.
} 
interests of the community directly translate into the interests of individuals is flawed. ${ }^{336}$

This calls into question the effectiveness of the Fijian Administration in its primary mission - to improve the welfare of all indigenous Fijians. ${ }^{337}$ Ironically, Mahendra Chaudhry's 'Indian' government did more to help poor Fijians than any 'Fijian'

government had in the past. Durutalo argues that there is a link between the ${ }^{66}$ indigenous ruling class" and "foreign capital". ${ }^{338}$ In other words, many of the state's (matanitu's) development policy are conceived more with an eye to reinforcing the economic position of the ruling class rather than benefiting the average Fiji Islander.

The Fijian Administration has become synonymous with Fiji's traditional leadership. Many officials in the Fijian Administration are chiefs and those who aren't are often treated as though they are. ${ }^{339}$ Moreover, as Ratu Meli Verebalavu argues, "people use both their modern and traditional roles as a means of earning more money for themselves. 9340 The Fijian Administration continues to play a strong part in the nexus of interests that form the military-traditional complex. Ratuva writes that the FAB and

\footnotetext{
${ }^{336}$ Ratuva 211.
}

337 See Mahendra Reddy and Biman Prasad, "Affirmative Action Policies and Poverty Allieviation: A Case Study of Fiji Governments Farming Assistance Scheme," http://www.fdc.org.au/files/reddy.pdf (accessed May 1, 2003), p. 8.The Qarase government has already been implicated in economic mismanagement and corruption surrounding a scheme to provide implements for Fijian farmers. The scheme was put into place by Qarase's interim government and amounted to $1.8 \%$ of the government's budget. Suncourt Hardware (a private sector partner in the scheme) effectively siphoned profits off of the program by of fering the government inflated price figures. Much of the funds were also used for purposes other than what the program intended. Prime Minister Qarase himself is a former director of the FDB and board member of Fiji Holdings.

${ }^{338}$ Durutalo 193.

339 Nayacakalou 120.

340 Durutalo 105 and Nayacakalou 104. There is often a difficulty in bringing traditional concepts into modern instifutions. An example of this is the 1957-1958 controversy in the Fiji Stevedores Union after a Tabua (a sperm whale's tooth, the Tabua is traditionally used as a sort of offering) was presented to the union in a soro (ceremony of atonement) by a secretary who had embezzled money and who was never imprisoned. One critic, writing under the pseudonym Malokai wrote "the union is a Vavalagi [foreign] form of association in which it is not right to use Fijian $i$ vakarau [customs, rules], for the two conflict. It is not possible to present tabua to the companies in order to obtain a wage increase." The same debate occurred when the soldiers who took part in the 2000 coup and mutiny presented a soro to the Great Council of Chiefs. 
NLTB are regarded as daweiqoravi (servants) of the chiefs. ${ }^{341}$ The heavy emphasis placed on the development needs of ethnic Fijians over all other ethnic groups has meant that the "distinction between state interests and communal interests became blurred.".342 The Fijian administration has made ethnicity a criterion for the distribution of resources and in this way has accorded with Crawford's conditions for the politicisation of ethnic identity. This open institutionalisation of ethnicity strengthens ethno-political affiliation in that ethnic group membership earns certain rewards. As incentives for ethnic alignment increase so does the politicisation of ethnicity.

\section{e.) Fiji Military}

The military in Fiji is heavily politicised and has often interpreted its role in the country going beyond executing the orders of civilian politicians, to ensure that Fijian traditionalism itself was protected. The offspring of the ruling class often entered the army and thereby "the relationship between the Fijian ruling class and the military was strengthened."343 In a 1987 speech Indo-Fijian academic Vijay Naidu argued:

In Fiji, the predominance in the army of members of one ethnic category who are closely affiliated to the chiefly hierarchy that wields political power is a matter of concern. There is something immoral and sinister about the arming and training of one ethnic category in a multi-ethnic community. ${ }^{344}$

\footnotetext{
341 Ratuva 208.

342 Ratuva 210.

343 Durutalo 10.

Vijay Naidu, "Remembering Hiroshima," August 1987 and Vice Chancellor __, "USP Internal memorandum, August 6, 1987. Naidu's employer The University of the South Pacific (an institution which is based in Fiji and receives funding from the Government of Fiji) responded by scolding Naidu: "I must say that I think that in present conditions it was unwise to include direct and judgmental references to the political position in Fiji in an on-campus speech addressed to students."
} 
The military (or elements of the military) have intervened repeatedly (1987 and 2000) to restore the military-traditional complex to power. In retum, the power of the military was increased. The military has almost doubled in size since 1987 , despite economic difficulties in Fiji. ${ }^{345}$ The synergy between chiefly interests and the military establishment was fortified with the 1990 constitution, which placed the FMF "at the disposal and discretionary use of the Council of Chiefs-elected president."346

The main element of the FMF that participated in and supported the 2000 coup was the Counter Revolutionary Warfare Unit (CRWU) or First Meridian Squadron (FMS). The CRWU was created by Rabuka after the 1987 coup as a sort of Praetorian Guard, and placed under the command of Ilisoni Ligairi. ${ }^{347}$ In 1998 the unit was renamed the First Meridian Squadron and put under the command of Penaia Baleinamau. The unit remained fiercely loyal to Rabuka and often conducted training exercises at his estate near Savusavu. The fact that the 2000 coup leaders expected the support of the military but did not receive it (after some hesitation) was indicative of the major divisions between the FMS and the FMF. When the military finally did intervene in 2000 it succeeded in alienating the indigenous nationalists, who argued that the military was no longer serving the people (the people being indigenous Fijians). ${ }^{348}$ The First Meridian

\footnotetext{
345 Robertson and Sutheriand 3.

346 Durutalo 141 .

347 Ligairi was a fomer British SAS officer who had been caught smuggling weapons from Northern Ireland into the Republic of Ireland. After Ligairi left the CRWU it was placed under the command of Rabuka's coup co-conspirator Lt. Colonel Naivaluvu. Despite this Ligairi contimued to have a role. 348 Interview with Samisoni Speight Tikoinasau, 6 December, 2002. When 1 asked Samisoni Speight Tikoinasau (brother of George Speight, an MP for Tailevu North, and a member of the nationalist party the Conservative Alliance Matanitu Vanua Pary) if the FMF had betrayed indigenous rights through its actions in the events of 2000 coup he responded, "to some extent, yes... George would not have taken this action without military backing...he knew he had their support.. .they backed away."
} 
Squadron had close ties to the nationalist movement harboured "resentment" towards FMF Commander Commodore (now Rear Admiral) Frank Bainimarama. ${ }^{349}$

The November mutiny (led by Captain Shane Stevens) was also a strong sign of the major political fissures in the military. The mutiny was a vicious battle between the First Meridian Squadron and the regular forces. ${ }^{350}$ Rabuka was seen at the barracks at the time of the mutiny in full military uniform, driving away with one of the mutinying officers. To many people this implicated Rabuka in involvement in the mutiny. Rabuka strongly denied the allegations and claimed that he was at the barracks to act as a mediator. Contrary to this denial, infantry officer Taliai Rasolo claims to have seen Rabuka at Captain Steven's house several times before the mutiny. ${ }^{351}$

The Fiji Military Forces are heavily politicised. Ratu Jone Madraiwiwi argues that the military's loyalties are to the Great Council of Chiefs, the President, and the State - in that order. ${ }^{352}$ Mahendra Chaudhry reflected on the role of the FMF in the 2000 coup:

If the military wanted to, it could have been over in two hours... it is not there to serve the government of the day, unless of course the government is a Fijian government. They had mixed loyalties... it is not a professional army in the sense that it has been politicised. ${ }^{353}$

\footnotetext{
349 Interview with Taliai Rasolo (Suva, Fiji: 6 December, 2002). There were other people in the FMF who did not like Bainimarama because he came from the Navy rather than the Amy.

350 Rasolo (interview). When the FMS first attacked the Nabua barracks they executed several regular soldiers in their sleep. They then proceeded to unsuccessfully attempt to capture their foe - the commander of the FMF Commodore Bainimarama. The regular forces responded to this brutality in kind by taking several CRWU members who were not present at the mutiny, executing them at the barracks, and claiming that they died in action. When the FMF later raided George Speight's camp they also used "more than the nomal force," according to infantry officer Taliai Rasolo.

351 Rasolo (interview).

352 Madraiwiwi 10.

353 Chaudhry (interview).
} 
The military's place in Fijian society has sometimes been conceived as being a modern Bati (or warrior clan). ${ }^{354}$ After the 1987 coup, an army article in the Fijian weekly Nai Lalakai argued "the army is trying to protect the chiefs and their people...It is the duty of the warrior tribe to protect the chief..."355 To use Cynthia Enloe's terminology, the Fiji Military Forces soldiers are ethnic soldiers. ${ }^{356}$ The composition of the forces is over $90 \%$ ethnic Fijian. Furthermore, the army is dominated by people from a few provinces (in the East). The army has repeatedly intervened in Fijian politics to restore Fijian paramountcy and the military-traditional complex. ${ }^{357}$

There are some indications that, like the church and the chiefs, the political power of the military is weakening somewhat. Sam Speight (a conservative Fijian MP and George Speight's brother) argues that its commonly believed that "the allegiance of the military is to the vanua... but recent events have shown that it has shifted its focus." seems as though the bond between the military and the traditional order is now in jeopardy. There are those in the military who want to transform the forces into a professional institution and those who think that the main role of the military should be to support the "traditional" order. ${ }^{359}$

The military has acted as the primary coercive force in the military-traditional complex. The complex has, in turn, mobilised Fijian ethnic identity to advance its interests (including those of the military). In many ways, the primary role of the military

\footnotetext{
354 Rabuka himself was a member of the Bati.

355 Norton 139.

356 Cynthia H. Enloe, Ethnic Soldiers, (Suffolk, United Kingdom: Pelican Books, 1980) 129. Enloe notes that in cases of coups ethnic politics usually become more polarised. Moreover, in cases of military coups, the "armed bureaucracy" usually increases in power

357 Moreover, it was the Fiji Military Forces that were deployed against Indian unrest in the sugar famer's strike of 1960 .

358 Tikoinasau.
} 
has not been to provide security for the state of Fiji but rather to provide ethnic security for Fijians. The military is a product of the politicisation of ethnicity but it also contributes to that politicisation by intensifying ethnic polarisation through its political interventions on behalf of Fijians.

\section{f.) Tradition and Democratic Politics in Fiji}

Many commentators and politicians have argued that 'western' democracy is somehow ill-suited to Fiji and that an idiosyncratic democratic system needs to be developed by Fijians that reflects their particular cultural context and traditions. ${ }^{360}$ The tradition that traditionalists embrace is not pre-colonial but a frozen and distorted version of the Fiji that existed just after British annexation. There are some contradictions inherent in the attempts by the chiefly institutions to play a primary role in the "modem" bureaucratic constructs of the Fijian Administration. In fact, the SVT actively utilised the Fijian Administration to bring its policy proposals before provincial and local councils. The chiefs used their natural authority in the Fijian traditional system to garner support for the party. ${ }^{361}$ Thus the military-traditional complex has at times used democratic politics to further its power.

Much of the discourse on developing a more "Fijian" political system is centred around the notion of incorporating Fijian traditionalism into the democratic system. In

\footnotetext{
359 Which side will be victorious has yet to be decided, but it will be interesting to see what sort of leader replaces Bainimarama when his term ends.

360 Lawson 162. Such a system would differ from the west in that chiefly power (at least in modern times) is essentially authoritarian in nature. This partly flows from an ideology constructed by the west of "the superiority of the original... over and above anything contaminated by external (especially western) influences." There is also deep inconsistency to the traditionalists' rejection of western values; the most significant western import, namely Christianity, has been accepted whole-heartedly!

${ }^{361}$ Durutalo 166. As one man on Malolo (an island in the Mamanuca group) explains, "I support the SVT because it is a chiefly party. Other political parties are not part of the Fijian leadership system."
} 
this sense, alternative democratic conceptions will, almost certainly, reinforce the power of ethnic Fijians. Democratic politics has, in the past, favoured Indians because of their demographic majority. With the changing demographic balance of power this may be less true now and Fijian nationalists may feel less of a need to incorporate "tradition" into the political system as a means of ensuring Fijian paramountcy.

\subsection{Conclusion}

In both Fiji and New Caledonia an entrepreneurial governing elite has utilised ethnicity in order to mobilise political support and protect its interests. This political manipulation of ethnic identification directly contributes to the politicisation of ethnicity. In New Caledonia, the economic interests of the Caldoches and the French State are directly threatened by the ascendancy of Kanak socialist independence. The Kanaks are demanding a greater share of the economic wealth and resources of New Caledonia. The governing elite (the RPCR State) is actively resisting change through various means including demographics (the importation of a large number of settlers from France and Polynesia), and coercion (through the military and police). It is in the interests of this elite to make ethnic appeals to all of the Europeans of New Caledonia to combat the Kanak "threat" to the survival of their culture and way of life. In turn, the power of the RPCR has alienated Kanaks from the state and contributed to their defensive politicisation.

In Fiji, the military-traditional complex dominates the economic, political, and security institutions of the state. This governing elite feeds on the fear of Indian dominance and appeals to Fijians for unity. Moreover, it has constructed a discourse 
focussed on notions of Indian "threats" to Fijian society and political paramountcy, a discourse which helps it to build the ethnic cohesion necessary for the maintenance of its own power. Fijian political control is only possible if Fijian institutions such as the church, army, and Fijian Administration retain a great deal of power and privilege. There are some indications that the power of the military-traditional complex is weakening somewhat. It is quite possible that as Indians have emigrated from Fiji that the Fijians' perceived threat to their political hegemony has been reduced and thus incentives for building ethnic cohesion around traditionalism have also decreased.

The juxtaposition of the RPCR State (a predominately European governing elite) and the military-traditional complex (a predominately Fijian governing elite) imparts some interesting evidence for the validity of Crawford and Lipschutz's arguments. Both the Fijians and the Kanaks are highly politicised yet in the case of Fiji, Fijians effectively control much of the power of the state. In such circumstances it becomes increasingly difficult to argue that the politicisation of ethnicity (in this case the Fijians) is merely a product of marginalisation. The politicisation of Fijian ethnicity is not a response to external discrimination but rather represents Fijian desires to exercise control over the state. This desire for control is rooted in the principle of the nation-state, which posits that the nation and the state must be synonymous. Thus, Fijian politicisation seeks state control as a means of fulfilling the national aspirations of the indigenous Fijian people. 


\section{Conclusion}

\subsection{Introduction}

This thesis has attempted to answer the important and complicated question of how ethnicity becomes politicised. The challenge in answering this question arises from

the complexity of personal identity and affiliation itself. There is also a great diversity of historical experience and circumstance that shapes both the emergence and form of politicised ethnicities.

As a starting point the instrumentalist, "cultural conflict" argument of Crawford and Lipschutz was examined. Instrumentalism has great utility in the analysis of the politicisation of ethnicity because of its emphasis on the fluidity of ethnic identification and the political aspects of ethnicity. Crawford and Lipschutz contend that ethnic identity is transformed from a social phenomenon to a political force when it becomes a source of discrimination. This type of politicisation (which I have called "defensive") does occur in many cases.

However, politicisation can also occur in cases without such marginalisation, cases where politicisation is more a product of national imagining and positive entitlements ("assertive" politicisation). Both of these manifestations of politicised ethnicity are rooted in a group's perceived lack of control, a perception that is forged by factors such as political and economic inequalities and historical memory. The same factors that facilitate the initial politicisation of identity also serve to sustain ethnopolitical movements. 
In order to examine both Crawford and Lipschutz's propositions, and our modifications to these propositions, the cases of Fiji and New Caledonia were compared. These cases were selected because it would appear that although each possesses a high degree of ethnic politicisation, the politicisation of the Fijians of Fiji has occurred largely without their marginalisation, whereas in New Caledonia Kanak politicisation is a product of such marginalisation. This chapter will first review and summarise the findings of this thesis, then offer a future prognosis for the politicisation of ethnicity in Fiji and New Caledonia, and finally, in concluding, it will discuss the implications of these findings within a comparative perspective.

\subsection{Evidence/Summary}

\section{a.) Introduction}

Each chapter in this thesis examined a different aspect of the politicisation of ethnicity in Fiji and New Caledonia. Chapter Two provided a historical perspective on the politicisation of ethnicity in our cases. Chapters Three and Four dealt with ethnic politics and factors influencing the continuing politicisation of ethnicity in contemporary New Caledonia and Fiji respectively. Finally, Chapter Five investigated the role of goveming elites in politicisation.

\section{b.) Historical Analysis: The Politicisation of Ethmicity over Time in Finilind Caledonia (C)apter 具。)}

The politicisation of ethnicity does not occur in a vacuum but rather has developed as a result of historical events and processes. In Fiji and New Caledonia, the 
nature of national and ethnic identity has evolved substantially over time. In the precolonial period both territories lacked a 'national' consciousness or sense of a cohesive identity binding all the peoples of the territory together. In this sense, identity was fragmented yet it was also somewhat homogenous due to the lack of ethnic and religious diversity within the political space. The colonial state dramatically altered this situation by imposing a central government and facilitating the mass immigration of other groups who were culturally and physically very different from the indigenous population. British and French colonialism also introduced ethnic segregation and stratification.

However, there were also significant differences between the colonial policies of the British and French. French colonialism in New Caledonia sought to eliminate Kanak identity while the British system of indirect rule which was instituted in Fiji, for the most part, paternalistically protected Fijian culture and land rights. Moreover, the Fijians received relatively better treatment than other ethnic groups in Fiji. Yet despite the differing colonial experiences of Fijians and Kanaks, ethnicity has become politicised in both cases. Furthermore, both cases have been defined by the struggle to shape the identity of the post-colonial state.

\section{c) Contemporary cthnic Politics and Politicisation (Chapters III. and $\mathrm{V}_{\text {. }}$ )}

The politicisation of ethnic identity occurs as a result of certain factors including such things as economic inequality, the distribution of political power, historical memory, land rights, and relative demographic strength. In both Fiji and New Caledonia ethnic competition is largely bipolar (it revolves around two main groups). Fiji's politically and demographically dominant ethnic groups are the Fijians and Indians while in New 
Caledonia bipolar competition is centred on the Europeans and Kanaks. Moreover, both states have other groups (such as Rotumans in Fiji and Wallisians in New Caledonia) which have traditionally allied with a larger group to advance their interests.

Economic inequality is one factor that contributes to politicisation. In Fiji, Indians are perceived as being economically dominant, a perception which has fuelled Fijian fears of a loss of control and ultimately their politicisation. Moreover, Kanak resentment over their relative poverty and economic marginalisation has been a primary element in the birth of the indigenous nationalist movement in New Caledonia.

Similarly the distribution of political power and the relative demographic strength of groups can fuel politicisation. The Fijians have been politically dominant in postcolonial Fiji yet they lack the capacity to build a uniquely Fijian state, in their view due to the presence of a large Indo-Fijian population. In New Caledonia the Kanaks have long been politically marginalised and reduced to a minority within their own land. In such situations of ethnic competition relative demographic strength becomes a problematic determinant of power.

Historical memory also plays a significant role in the politicisation of ethnicity in both Fiji and New Caledonia. A group's historical experiences are often viewed through the lens of contemporary political conflicts. Historical narratives of marginalisation and suffering may play a large part in the defensive politicisation of ethnicity. Furthermore, historical narratives form the basis of many assertive political movements as groups such as the Fijians assert positive entitlements (in this case based on the notion of indigenous paramountcy) as the basis for their political movement. The assertion of these indigenous entitlements is anchored in the Fijians' and Kanaks' long historical presence on the land. 
A final factor that contributes to the politicisation of ethnic identity in our cases is land rights. Land represents a potent symbol of a group's identity, power, and stability. For the indigenous peoples of Fiji and New Caledonia, the feared loss of control over their land represents a powerful motive for politicisation. However, indigenous Fijians have been allowed to maintain a high degree of control over traditional lands, whereas Kanaks have largely lost this control.

Identity is a complex phenomenon and ethnic identity coexists with other forms of non-ethnic identity that may also become politicised. These non-ethnic factors can either reinforce or challenge the primacy of ethnicity. As ethnic power becomes less contested, non-ethnic factors increase in importance. In both Fiji and New Caledonia, these nonethnic aspects of identity include such things as class, religion, and regionalism.

\section{d.) Governing Elites and the Politicisation of Ethnicity (Chapter V.)}

Leaders and the elites to which they belong have a primary role in the politicisation of ethnicity. The political mobilisation of ethnicity cannot occur without leaders. They can contribute to the politicisation of ethnicity both through the rhetoric that they employ to gain power as well as the way that they exercise this power. Moreover, leaders and governing elites rely on certain conditions being present in order to mobilise the support of a constituency.

In both Fiji and New Caledonia particular elites have exercised control over the state for many years. In New Caledonia the main elite is the predominately-European RPCR state: a confluence of economic and political interests including (but not limited to) the French imperial state, European settlers in New Caledonia, the RPCR party, and 
the media. Fiji is governed largely by the predominately Fijian military-traditional complex, a matrix of power including the Methodist Church, Fiji Military Forces, Fijian Administration, and the chiefly aristocracy. Yet both of these elites have utilised ethnicity to further their interests and consolidate their power. In doing so they have institutionalised ethnicity, stirred ethnic fears, and contributed to the marginalisation of particular groups. These governing elites employed ethnicity to gain power and are reliant on the political saliency of ethnicity to maintain their power.

\subsection{Prognosis: The Future of Politicised Ethnicity in Fili and New Caledonia}

In this thesis my analysis of Fiji and New Caledonia has only focussed on the collection of evidence on the historical and contemporary politicisation of ethnicity but this section will attempt to extrapolate our data in order to offer a future prognostication for each case. In both cases the short-term outlook is that the politicisation of ethnicity will remain strong and ethnicity will still be the primary political factor. In New Caledonia there are increasing attempts to construct new, inclusive national institutions and an accompanying new civic nationalism that includes all ethnic groups. Despite these efforts New Caledonia remains a very polarised state. If the government is successful in reducing inequalities between the Kanaks and Europeans, and Kanak alienation, then it is quite likely that the politicisation of ethnicity will gradually decrease.

In Fiji, politics remain ethnically polarised and there seem to be few genuine attempts at reconciliation. Fijian nationalists retain control of the government and are more interested in ethnicising the state (to make it more Fijian) than in multiculturalism or accommodation of the Indian fact in Fiji. With continuing Indo-Fijian emigration, 
Fijians will likely consolidate their control over the state. As Fijian control becomes more assured, ethnicity will become less of a political factor. With this decline in the 'weight' of ethnic factors in the political life of Fiji, intra-ethnic competition will likely increase.

\subsection{Conclusion}

The question of how ethnicity becomes politicised is one that has no facile answer. Individuals congregate (through self-identification and ascription) into groups. These groups feel a sense of distinctiveness and, in certain circumstances, this can take on political overtones. The stratification of groups can create competition as a group comes to feel that its interests or very survival are at stake. Ethnicity becomes politicised when it is transformed from a social to a political phenomenon. Crawford and Lipschutz argue that the transformation of ethnic identity occurs when ethnicity becomes a criterion for the distribution of resources. That is to say that ethnic privilege and discrimination become institutionalised in the state.

This is partially correct in that when there is an unequal distribution of resources (whether they are political, economic, or otherwise) a group may become marginalised from the state and this can be a powerful incentive for political mobilisation. However, this defensive politicisation represents only one possible medium for the politicisation of ethnicity. Politicisation can also occur in the absence of hardship in situations where a group has a sense of distinctiveness (assertive politicisation). Such politicised ethnicities may also become ethno-nationalist movements seeking the construction of a nation-state. This assertive politicisation is grounded in notions of positive entitlement rather than 
being a reactionary politicisation born in discrimination at the hands of the state or another group.

The fundamental causation for both of these types of politicisation is a group's perceived lack of control, a perception that may be rooted in such factors as economic and political inequalities, historical memory, and land rights. Moreover, governing elites may utilise the presence of these factors to mobilise ethnicity in service of their political ends. Once in control of the state, these elites seek the continuation of the politicisation of ethnicity in order to maintain their power.

This thesis has constructed this dichotomy of defensive and assertive politicisation as a conceptual framework for the critique of Crawford and Lipschutz. It is useful here to re-examine the utility of these concepts. While it is true that the politicisation of ethnicity, in many cases, is not solely a result of discrimination or hardship it is also difficult to define and separate defensive and assertive causation. As previously stated, these concepts are not mutually exclusive and both phenomena are often present. An ethnic group that politically mobilises often does so for many reasons. Ethno-nationalist narratives may invoke both aspirations to freedom from persecution and the pursuit of political goals arising from distinctive national histories. Moreover, as ethnic identification is relational, politicisation is not possible without the presence of a level of ethnic consciousness that acknowledges the unique attributes of the group. Furthermore, assertive politicisation may also spawn defensive politicisation as the rising status of one ethnic group provokes ethnic security dilemmas where other groups mobilise in reaction to what is perceived as a threat to their status. Consequently, although the terms "assertive" and "defensive" politicisation are of somewhat limited 
utility, at least they do provide a useful conceptual framework to illustrate that the politicisation of ethnicity may occur in a variety of ways (rather than just through adversity).

Fiji and New Caledonia provide us with corroborative evidence for these arguments. Ethnicity in both cases has become stratified and politicised over time. Moreover, the intervention of colonialism also coincided with the introduction of large immigrant populations. However, the colonial treatment of the Fijians and Kanaks differed greatly. The French sought to completely subsume (or even eliminate) Kanak identity, confiscated Kanak land, largely denied the Kanaks any economic or political control over their homeland. In contrast, Fijian identity and land rights were largely maintained by the British, and the British system of indirect rule utilised indigenous Fijian leaders in colonial governance institutions. Moreover, in the past several decades the Europeans have dominated the govermment of New Caledonia while Fijians have maintained political control in Fiji. Nonetheless, politicisation occurred in both cases. The Fijians have not become politicised primarily as a result of marginalisation but rather in order to pursue their goal of a Fijian nation-state.

After reviewing a variety of theoretical approaches to ethnic identification, and commenting on their relative usefulness for understanding ethnic politicisation, the instrumentalist approach of Crawford and Lipschutz was selected as the most advantageous. It has been the central intention of this thesis to test the utility of Crawford and Lipschutz's approach to ethnic politicisation through the examination of two contrasting neighbouring states in the South Pacific region. I have suggested moving beyond this model by differentiating between what I have called assertive versus 
defensive politicisation. In retrospect, in this study 1 have found that amongst Fijians in Fiji assertive politicisation seems to prevail, whereas in New Caledonia European state control and Kanak nationalism seem to be more characteristic of defensive politicisation, implying marginalisation thereby supporting Crawford and Lipschutz's emphasis. Yet the very contrast between the two cases examined in this thesis would seem to suggest, then, the relativity of abstract/generalised theoretical constructs which may fit one particular case but not another. The explanatory potential of such generalised models, therefore, concomitantly depends upon the historical and contemporary complexity of particular cases. 


\title{
Appendix: British Colonial Administration in Fiji
}

\author{
Govermor \\ Native Council \\ Roko Tui (Provincial Chief) \\ Provincial Councils \\ Buli (District Chief) \\ District Councils \\ Village Chiefs \\ Turaga ni Koro (Village Mayor) \\ Commoners in the Villages
}

The Roko Tui, Buli, and Turaga ni Koro were administrative positions created by the British, yet they have been fully incorporated into what most people now consider the Fijian traditional system. ${ }^{2}$ All of these institutions were (and are) part of the Fijian administration which govemed the affairs of indigenous Fijians.

1 Adapted from Alumita Lawaniyavi Durutalo, Provincialism and the Crisis of Indigenous Fijian Political Unity, thesis submitted to meet the requirements of MA, University of the South Pacific, 1997, 8. 2 The position of Buli no longer exists. 


\section{Appendix 2: Interviews}

Formal Interviews (All interviewees signed informed consent forms and are identified by name). All interviews in New Caledonia were conducted in French and translated by the author.

Ali, Ahmed. 9 December, 2002. Suva, Fiji.

Aloisi, Sako. 9 August, 2002. Nouméa, New Caledonia.

Chaudhry, Mahendra. 9 December, 2002. Suva, Fiji.

Dakavula, Jone. 9 December, 2002. Suva, Fiji.

Mua, Colonel Metuisela. 4 December, 2002. Suva, Fiji.

Poaouteta, Ferdinand. 1 August, 2002. Koné, New Caledonia.

Pabouty, Raymond. 22 July, 2002. Nouméa, New Caledonia.

Pabouty, Sylvain. 7 August, 2002. Nouméa, New Caledonia.

Rasoloa, Taliai. 6 December, 2002. Suva, Fiji.

Speight, Samisoni Tikoinasau. 6 December, 2002. Suva, Fiji.

Tutugoro, Victor. 7 August, 2002. Nouméa, New Caledonia.

Vittori, Pascal. 8 August, 2002. Nouméa, New Caledonia.

Vunibobo, Berenado. 5 December, 2002. Suva, Fiji.

Wea, Charles. 8 August, 2002. Nouméa, New Caledonia.

Yabaki, Akuila. 7 November, 2002. Suva, Fiji.

\section{Informal Interviews (Anonymous, no informed consent forms) ${ }^{1}$}

Member of Lau Provincial government. 14, October, 2002. Lakeba, Fiji.

Kanak woman. 19 July, 2002. Nouméa, New Caledonia.

Chinese shopkeeper. 5 August, 2002. Nouméa, New Caledonia

1 Only those informal interviewees quoted in the thesis are referenced. 


\section{Bibliography}

Akram-Lodhi, A. Haroon (ed.). Confronting Fiji Futures. Canberra, Australia: Asia Pacific Press, 2000.

Aldrich, Robert and John Connell. France's Overseas Frontier: Départements et Territoires d'Outre-Mer. Hong Kong: Cambridge University Press, 1992.

Ali, Ahmed. Plantation to Politics: Studies on Fiji Indians. Suva, Fiji: University of the South Pacific, 1980.

Anderson, Alan B. "The Complexity of Ethnic Identities: A Postmodern Reevaluation." Identity, 1 (3), 2001.

Anderson, Kjell and Alan B. Anderson. "Nationalism in New Caledonia." Canadian Review of Studies in Nationalism, forthcoming 2004.

Arreghini, L. and P. Waniez. La Nouvelle-Calédonie en tournant des années 1990. Nouméa: Gouvernement de la Nouvelle-Calédonie, 1993.

Baleiwaqa, Tevita "Reflections on the Civilian Coup in Fiji," in Brij Lal and Michael Pretes (eds.), Coup. Canberra, Australia: Pandanus Books, 2001.

Bell, D. "Ethnicity and Social Change," in N. Glazer and D.P. Mognihan (eds.), Ethnicity: Theory and Experience. Cambridge, MA: Harvard University Press, 1975.

Bensa, A. and I. Leblic (eds.). En Pays Kanak. Mission du Patrimoine ethnologique, Cahier 14. Paris: Editions de la Maison des Sciences de l'Homme, 2000.

Berghe, P.L. van der. Does Race Matter? New York: Elsevier, 1981.

Bernut-Deplanque, Pascale. L'identité Culturelle Calédonienne: Construire Possible ou Utopie?. Nouméa: lle de Lumière, 2002.

Bril, I. "Enquête linguistique et enjeux culturels," in A. Bensa and I. Leblic (eds.), En Pays Kanak. Mission du Patrimoine ethnologique, Cahier 14. Paris: Editions de la Maison des Sciences de l'Homme, 2000.

Brou, B. Peuplement et Population de la Nouvelle-Calédonie. Nouméa: Publications de la Société d'Etudes Historiques de la Nouvelle-Calédonie, 1980.

Brown, Michael E. "The Causes of Intemal Conflict," in Michael E. Brown, Owen R. Coté, Sean M. Lynn Jones and Steven E. Miller (eds.), Nationalism and Ethnic Conflict. Cambridge, Massachusetts: The MIT Press, 2001. 
Centre culturel Tjibaou. Mwakaa: The Pathways of Kanak Tradition. Nouméa: Centre Culturel Tjibaou, 2000.

Chanter, A. "The Production of Social Disorder: The Example of the Daily Press in New Caledonia. In S. Dinnen and A. Ley (eds.), Reflections on Violence in Melanesia, Canberra: Hawkins Press and Asia Pacific Press, 2000.

Cohen, Abner. Customs and Politics in Urban Africa. Berkeley: University of California Press, 1969.

Connell, John. New Caledonia or Kanaky. Canberra: National Development Studies Centre, 1987.

Cornell, S. and Hartmannn, D. Ethnicity and Race: Making Identities in a Changing World. Thousand Oaks, CA: Pine Forge Press, 1998.

Couture, Jocelyne, Kai Nielson, and Michel Seymour. Rethinking Nationalism, Calgary: University of Calgary Press, 1998.

Crawford, Beverly. "The Causes of Cultural Conflict: An Institutional Approach," in Beverly Crawford and Ronnie D. Lipschutz (eds.), The Myth of Ethnic Conflict. Berkeley, California: University of California, 1998.

Crocombe, Ron. The South Pacific. Suva, Fiji: Institute of Pacific Studies, 2001. , Uentabo Neemia, Asesela Ravuvu, and Werner Von Busch (eds.). Culture and Democracy in the South Pacific. Suva, Fiji: Institute of Pacific Studies, University of the South Pacific, 1992.

and Malama Meleisea (eds.). Land Issues in the Pacific. Suva, Fiji: Institute of Pacific Studies, University of the South Pacific, 1994.

Dinnen, S. and A. Ley (eds.). Reflections on Violence in Melanesia. Canberra: Hawkins Press and Asia Pacific Press 2000.

Dobell, Graeme. "The Strange Saga of Speight's Siege in Suva," in Brij Lal and Michael Pretes (eds.), Coup. Canberra, Australia: Pandanus Books, 2001.

Dommel, D. La Crise Calédonienne: Remission ou guérison?. Paris: Editions l'Harmattan, 1993.

Doombos, Martin and A. Haroon Akram-Lodhi. "Introduction: Confronting the future, Confronting the Past," in Haroon Akram-Lodhi (ed.), Confronting Fiii Futures. Canberra: Asia Pacific Press, 2000. 
Dornoy, M. Politics in New Caledonia. Sydney: Sydney University Press, 1994. Politics and Perceptions of France in the South Pacific: New Caledonia and Vanuatu. Suva: Institute of Pacific Studies and University of the South Pacific, 1994.

Douglas, B. "Weak States and Other Nationalisms: Emerging Melanesian Paradigms?" State, Society and Governance in Melanesia Project, Research School of Pacific and Asian Studies, Australian National University, Discussion Paper 00/3 (2000).

Doumenge, Jean-Pierre. "New Caledonia from the Human Angle," in Christine Jost (ed.), The French-Speaking Pacific. Mount Nebo, Australia: Boombana Publications, 1998.

Durutalo, Alumita. Provincialism and the Crisis in Fiiian Political Unity. MA Thesis, University of the South Pacific, December, 1997.

Dussy, D. "La mémoire kanak de Nouméa," in A. Bensa and I. Leblic (eds.), En Pays Kanak. Mission du Patrimoine ethnologique, Cahier 14. Paris: Editions de la Maison des sciences de l'homme, 2000.

Enloe, Cynthia H. Ethnic Soldiers. Suffolk, United Kingdom: Pelican Books, 1980.

Ewins, Rory. Changing Their Minds: Tradition and Democratic Politics in Fiii and Tonga. Christchurch, New Zealand: Macmillan Brown Centre for Pacific Studies, 1998.

Fiji Islands Bureau of Statistics. Fiji Facts and Figures. Suva, Fiji: Fiji Islands Bureau of Statistics, 2002.

Franceschi, General Michel. La Démocratie Massacrée: Nouvelle-Calédonie Temoignage. Paris: Editions Pygmalion/Gérard Watelet, 1998.

Geertz, Clifford. Old Societies and New States. New York: Free Press, 1963.

Geography Dictionary. http://www.geoexplorer.co.uk/sections/dictionary/c.htm. Accessed on July 20, 2003.

Glazer, Nathan and Daniel P. Moynihan (eds.). Beyond the Melting Pot. Cambridge, USA: The MIT Press, 1963.

Gordon, Milton M. Assimilation in American Life. New York: Oxford University Press, 1964.

Griffin, Chris and Mike Monsell-Davies. Fijians in Town. Suva, Fiji: University of the South Pacific, 1986. 
Hall, S. "The New Ethnicities," in J. Donald and A. Rattansi (eds.), Race, Culture, and Difference. London: Sage, 1992.

Hamelin, C. "Les Gens de Nouméa: Mutations et permanences en milieu urbain." In Bensa, A. and I. Leblic (eds.), En Pays Kanak. Mission du Patrimoine Ethnologique, Cahier 14. Paris: Editions de la Maison des Sciences de l'Homme, 2000 .

Harris, Usha Sundar. "Outcasts of the Pacific" in Brij Lal and Michael Pretes (eds.), Coup. Canberra, Australia: Pandanus Books, 2001.

Horowitz, Donald L. Ethnic Groups in Conflict. Berkeley: University of California Press, 1985.

Hussain, Bernadette. "For Fiji and Rotuma: Constitution paper highlights native realities." Fiii Times. Tuesday, September 11, 2001: 7.

Institute of Pacific Studies (ed.). Pacific Indians. Suva, Fiji: Institute of Pacific Studies, University of the South Pacific, 1981.

Isaacs, H.R. Idols of the Tribe: Group Identity and Political Change. Cambridge, USA: Harvard University Press, 1975.

Jalal, Imrana. "Fiji's 2001 Elections: Rebuilding a Fractured Nation," in Kim Gravelle (ed.), Good Governance in the South Pacific. Suva, Fiji: University of the South Pacific, 2002.

Jost, Christian (ed.). The French-Speaking Pacific. Mount Nebo, Australia: Boombana Publications, 1998.

Kaplan, Martha and John D. Kelly. Represented Communities: Fiii and World Decolonization. Chicago: University of Chicago Press, 2001.

Kasarhérou, E. (ed.). Langues Kanak et Accord de Nouméa. Nouméa: Centre Culturel Tjibaou, 2000.

Kelly, John. "The Privileges of Citizenship: Nations, States, Markets and Narratives," in R.J. Foster (ed.), Nation Making: Emergent Identities in Postcolonial Melanesia. Ann Arbor, USA.: University of Michigan Press, 1995.

and Martha Kaplan. Represented Communities: Fiji and World Decolonization. Chicago: University of Chicago Press, 2001.

Kiran, S. "Bridging the ethnic divide." The Daily Post. March 30, 2002. 
Kohler, J.M. "Colony or Democracy? A Political Sociology of New Caledonia." Nouméa: Les Editions Populaires, 1987.

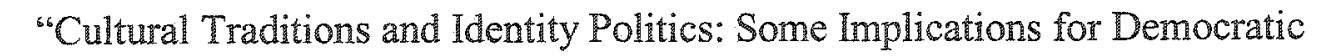
Governance in Asia and the Pacific", State, Society and Govemance in Melanesia Project, Research School of Asia and Pacific Studies, Australian National University, Discussion Paper 97/4, 1997.

Lake, David A. and Donald Rothchild. "Containing Fear: The Origins and Management of Ethnic Conflict," in Michael E. Brown, Owen R. Coté, Sean M. Lynn Jones and Steven E. Miller (eds.), Nationalism and Ethnic Conflict. Cambridge, Massachusetts: The MT Press, 2001.

Lal, Brij. Fiji Before the Storm: Elections and the Politics of Development. Canberra, Australia: Asia Pacific Press, 2000.

"The Sun Set at Noon Today" in Brij Lal and Michael Pretes (eds.), Coup.

Canberra: Pandanus Books, 2001.

and Michael Pretes (eds.). Coup. Canberra: Pandanus Books, 2001.

and Tomasi R. Vakatora (eds.). Fiji and the World. Suva, Fiji: School of Social and Economic Development, University of the South Pacific, 1997.

and Tomasi R. Vakatora (eds.). Fiii in Transition. Suva, Fiji: School of Social and Economic Development, University of the South Pacific, 1997.

Lasaqa, Isireli. The Fijian People: Before and After Independence 1959-1977. Canberra, Australia: Australian National University Press, 1984.

Lawson, Stephanie. Tradition Versus Democracy in the South Pacific: Fiii, Tonga, and Samoa. Cambridge, United Kingdom: Cambridge University Press, 1996.

Lindstrom, L. and G.M. White (eds.). Culture-Kastom-Tradition: Developing Cultural Policy in Melanesia. Suva: Institute of Pacific Studies, University of the South Pacific.1994.

Maclellan, Nic and Jacques Sarimin Boengkih. "France's Decolonization Process in New Caledonia: Conflict on the Path to Self-Determination." Australia-Pacific Community Network, Centre for Asia-Pacific Studies, Victoria University, Pacific Series, Working Paper no. 1 (1998).

Maclellan, Nic and Jean Chesneaux. After Moruroa: France in the South Pacific. Melboume: Ocean Press, 1998.

Madraiwiwi, Ratu Jone. "Fiji's 2001 Elections: Our Country at the Crossroads," in Kim 
Gravelle (ed.), Good Governance in the South Pacific. Suva, Fiji: University of the South Pacific, 2001.

Manueli, Irene. "Call to widen role of chiefs." Fiii Times. Friday, August 23, 2002:5.

Maroi, Reverend Ina. "Fijian Social Structure," (letter to the editor). Fiii Times. Sunday, October 6: 10.

Mayer, Adrian C. Indians in Fiii. London: Oxford University Press, 1963.

Merle, I. "De l'idée de cantonnement à la constitution des réserves: la définition de la propriétée indigène," in Bensa, A. and I. Leblic (eds.), En Pays Kanak, Mission du Patrimoine ethnologique, Cahier 14. Paris: Editions de la Maison des sciences de l'homme, 2000.

Milne, R.S. Politics in Ethnically Bipolar States. Vancouver: University of British Columbia Press, 1981.

Mishrah, Vijay. "Indo-Fijian Fiction and the Girmit Ideology," in Christ Tiffin (ed.), South Pacific Images. Australia: South Pacific Association for Commonwealth Literature and Language Studies, 1978.

Naepels, M. Histoire des Terres Kanakes. Paris: Editions Belin, 1993. "Partir à Nouméa: Remarques sur les Migrants Originaires de la Région Ajiè," in Bensa, A. and I. Leblic (eds.), En Pays Kanak. Mission du Patrimoine Ethnologique, Cahier 14. Paris: Editions de la Maison des Sciences de l'Homme, 2000 .

Naidu, Vijay. "An Indo-Fijian Perspective on Approaching Nation-Building." The Goodwill Conference for Fiji. Suva, Fiji, 2002.

. "Remembering Hiroshima." Seminar at University of the South Pacific, Suva, Fiji, August 1987.

and Ganesh Chand. Fiji: Coups, Crisis, and Reconciliation, 1987-1997. Suva, Fiji: Fiji Institute of Applied Studies, 1997.

Nayacakalou, R.R. Leadership in Fii. Suva, Fiji: Institute of Pacific Studies, 1975.

Ngwele, S. Bamboo Leaves. Vanuatu: USP Centre, 1988.

Niumataiwalu, Ana. "Indigenous concerns highlighted." Fiji Times. Friday, August 23, 2002: 5 .

Norton, Robert. Race and Politics in Fiii. Australia: Queensland University Press, 1990. 
Novak, M. Unmeltable Ethnics: Politics and Culture in American Life. London: Transaction, 1996.

Olzak, Susan and Joane Nagel. Competitive Ethnic Relations. London: Academic Press, 1986.

Ounei, S. "For Kanak independence: The fight against French rule in New Caledonia." Auckland: Labour Publishing Cooperative Society, 1985.

Ozanne-Rivière, F. "Terminologie de Parenté Proto-Océanienne: Continuité et Changement dans les Langues Kanak," in Bensa, A. and L.Leblic (eds.), En Pays Kanak. Mission du Patrimoine Ethnologique, Cahier 14. Paris: Editions de la

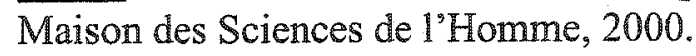

Park, Robert Ezra. Race and Culture. Glencoe, Illinois, USA: The Free Press, 1950.

Pasifik Nius. "Kanaks Mourn First Victim of Ethnic Tension." Nouméa: Oceania Flash, South Pacific Commission, 12 February 2002.

Patterson, Orlando. "Context and Choice in Ethnic Allegiance: A Theoretical Framework and Caribbean Case Study," in Nathan Glazer and Daniel P. Moynihan (eds.), Ethnicity: Theory and Experience. Cambridge, USA: Harvard University Press, 1975.

Pineau-Salaun, M. "Histoire et Memoire d'une Institution Coloniale: la Scolarisation des Kanak au Temps de 1'Indigènat," in Bensa, A. and I. Leblic (eds.), En Pays Kanak. Mission du Patrimoine Ethnologique, Cahier 14. Paris: Editions de la Maison des Sciences de l'Homme, 2000.

Premdas, Ralph R. "Seizure of Power, Indigenous Rights and Crafting Democratic Governance in Fiji." Nationalism and Ethnic Politics. 8 (4).

Ratuva, Steven. "Conflicting Perspectives and Potential for Accommodation in a Plural Post-Coup Society: Rebuilding a Fractured Fiji," in Brij Lal and Michael Pretes (eds.), Coup. Canberra: Pandanus Press, 2001.

- Ethnic Politics, Communalism, and Affirmative Action in Fiji: A Critical and Comparative Study. MA Thesis, Institute of Development Studies, University of Essex, 1999.

Ravuvu, Asesela. Development or Dependence. Suva, Fiji: University of the South Pacific, 1988.

The Facade of Democracy. Suva, Fiji: Reader Publishing House, 1995.

. The Fijian Way of Life. Suva, Fiji: University of the South Pacific, 1983. 
Reddy, Mahendra and Biman Prasad. "Affirmative Action Policies and Poverty Allieviation: A Case Study of Fiji Governments Farming Assistance Scheme." http://www.fdc.org.au/files/reddy.pdf (accessed May 1, 2003).

Reid, A.C. Tovata I \& II. Suva, Fiji: The Fiji Museum, 1990.

Robertson, Robbie. Multiculturalism \& Reconciliation in an Indulgent Republic: Fiii After the Coups: 1987-1998. Suva, Fiji: Fiji Institute of Applied Studies, 1998.

and William Sutherland. Government by the Gun: the Unfinished Business of Fiji's 200 Coup. Annandale, Australia: Pluto Press, 2001.

Robie, David. Blood on Their Banner: Nationalist Struggles in the South Pacific. London: Zed, 1990.

Roosens, Eugeen E. Creating Ethnicity: The Process of Ethnogenesis. Newbury Park, USA: Sage, 1989.

Rothschild, Joseph. Ethnopolitics: A Conceptual Framework. New York: Colombia University Press, 1981.

Secretariat of the Pacific Community. Fiji Islands Population Profile. Nouméa, New Caledonia: Secretariat of the Pacific Community, 1999.

- New Caledonia Population Profile. Nouméa, New Caledonia: Secretariat of the Pacific Community, 2001.

Sharpham, John. Rabuka of Fiji. Brisbane: Central Queensland University Press, 2000.

Shineberg, D. The People Trade: Pacific Island Labourers and New Caledonia, 18651930. Pacific Islands Monograph Series, no. 16, Center for Pacific Studies, Honolulu: University of Hawaii Press, 1999.

Singh, Raymond. "Mahogany - making a change." The Daily Post. Thursday, November 14, 2002: 5 .

Singh, Shubha. Fiji: A Precarious Coalition. Delhi: Har-Anand Publications, 2001.

Smith, Dan. The Penguin Atlas of War and Peace. Hong Kong: Penguin, 2003.

Soriano, E. "Tisser des Liens Politiques: Mobilisation Electorale et Vote Mélanesien (1946-58)," in Bensa, A. and I. Leblic (eds.), En Pays Kanak. Mission du Patrimoine Ethnologique, Cahier 14. Paris: Editions de la Maison des Sciences de 1'Homme, 2000. 
Steinberg, Stephen. The Ethnic Myth: Race, Ethnicity and Class in America. Boston: Beacon, 1981.

Stern S. and J.A. Cicala (eds.). Creative Ethnicity: Symbols and Strategies of Contemporary Ethnic Life. Logan, USA: Utah State University Press, 1991.

Terrier-Douyere et. al., Etre Caldoche Aujourd'hui. Nouméa: Ile de Lumière, 1996.

Tuwere, llaitia S. Vanua: Towards a Fijian Theology of Place. Suva, Fiji: Institute of Pacific Studies, University of the South Pacific, 2002.

Wassman, J. (ed.). Pacific Answers to Western Hegemony: Cultural Practices of Identity Construction. New York: Berg, Oxford University Press, 1998.

Waterhouse, Joseph. The King and People of Fiii. Auckland: Pasifika Press, 1997.

Williams, Esther Batiri and Kaushek K. Saksena. Labours Victory: Electoral Behaviour and Opinion in Fiii. Fiji: University of the South Pacific, 1999.

Yang, Philip Q. Ethnic Studies: Issues and Approaches. Albany: State University of New York, 2000. 